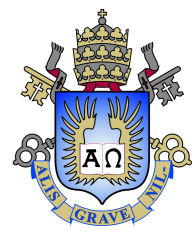

Júlia Nina Padilha

Toxicomanias: Percurso teórico no campo da Psicanálise

Dissertação apresentada como requisito parcial para obtenção do grau de Mestre pelo Programa de Pós-graduação em Psicologia Clínica do Departamento de Psicologia da PUC-Rio.

Orientadora: $\quad$ Prof ${ }^{a}$. Monah Winograd Co-orientador: Prof. Ney Klier Padilha Netto 


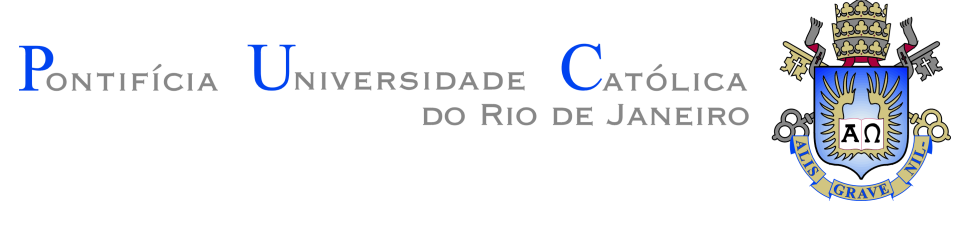

Júlia Nina Padilha

\section{Toxicomanias: Percurso teórico no campo da \\ Psicanálise}

Dissertação apresentada como requisito parcial para obtenção do grau de Mestre pelo Programa de Pós-graduação em Psicologia Clínica do Departamento de Psicologia da PUC-Rio. Aprovada pela Comissão Examinadora abaixo.

Profa. Monah Winograd

Orientadora

Departamento de Psicologia - PUC-Rio

Prof. Ney Klier Padilha Netto

Co-orientador

Departamento de Psicologia - PUC-Rio

Profa. Maria Isabel de Andrade Fortes

Departamento de Psicologia - PUC-Rio

Profa. Maria Virginia Filomena Cremasco

Universidade Federal do Paraná - UFPR

Rio de Janeiro, 26 de Junho de 2020 
Todos os direitos reservados. É proibida a reprodução total ou parcial do trabalho sem autorização da universidade, do autor e do orientador.

\section{Júlia Nina Padilha}

Graduou-se em Psicologia pela Universidade Federal do Maranhão, onde participou do grupo de pesquisa "Transmissão da Clínica Psicanalítica - Laço Social", integrou o projeto de extensão "Escuta", foi monitora do PRÓ-SAÚDE/PETSaúde na árvore Saúde Mental e voluntária na liga acadêmica para assistência materno-fetal (AMAFETO).

Ficha Catalográfica

Padilha, Júlia Nina

Toxicomanias: Percurso teórico no campo da Psicanálise / Júlia Nina Padilha; orientadora: Monah Winograd; coorientador: Ney Klier Padilha Netto. - 2020.

99 f. ; $30 \mathrm{~cm}$

Dissertação (mestrado) - Pontifícia Universidade Católica do Rio de Janeiro, Departamento de Psicologia, 2020.

Inclui bibliografia

1. Psicologia - Teses. 2. Drogas. 3. Álcool. 4. Toxicomania. 5. Adicção. 6. Psicanálise. I. Winograd, Monah. II. Klier Padilha Netto, Ney. III. Pontifícia Universidade Católica do Rio de Janeiro. Departamento de Psicologia. IV. Título. 


\section{Agradecimentos}

À minha orientadora Monah Winograd pelo acolhimento no programa de mestrado e compromisso com a realização deste trabalho.

Ao meu co-orientador Ney Klier, pela disponibilidade e por ser tão prestativo.

À CAPES pelos auxílios concedidos, fundamentais para a realização deste trabalho.

Aos meus pais Antônio Francisco e Lisianne, pelo exemplo, amor, apoio e incentivo dados a mim sempre. Sem vocês nada seria possível.

Às minhas irmãs Lorena e Lara, pelo apoio e alegria que trazem à minha vida.

À André Brandão pela constante parceria e incentivo nessa e em todas as minhas jornadas. Você foi essencial.

Aos amigos Álan, Ruberth, Dalai e Dieinison, com os quais partilho das dores e alegrias de migrar para estudar no Rio de Janeiro. Vocês tornam minha estadia aqui mais leve e especial.

Aos meus amigos de São Luís Lara, Júlia, Andréa, Mariana, Rafaelle, Marília, Ériko e Murilo que, mesmo à distância, são minha fonte de diversão diária.

À Rebecca pela preciosa amizade local. As trocas e apoio foram fundamentais nessa jornada final.

À Angela Villela pela escuta analítica tão necessária durante esse período de trabalho.

Aos professores da banca examinadora, por aceitarem contribuir com meu trabalho.

Aos professores e funcionários do Departamento de Psicologia da PUCRio pelos ensinamentos e pela ajuda.

O presente trabalho foi realizado com apoio da Coordenação de Aperfeiçoamento de Pessoal de Nível Superior - Brasil (CAPES) - Código de Financiamento 001. 


\section{Resumo}

Padilha, Júlia Nina; Winograd, Monah; Klier Padilha Netto, Ney. Toxicomanias: Percurso teórico no campo da Psicanálise. Rio de Janeiro, 2020. 92p. Dissertação de Mestrado - Departamento de Psicologia, Pontifícia Universidade Católica do Rio de Janeiro.

O uso de substâncias psicoativas sempre esteve presente na sociedade (de forma recreativa, terapêutica ou religiosa). A dependência em relação a essas substâncias, por sua vez, tem ocupado cada vez mais espaço na mídia e em discussões político-sociais que buscam entender o fenômeno. Questões culturais, sociais, econômicas, farmacológicas e psíquicas devem ser consideradas quando se propõem teorias e ações de tratamento. Esse trabalho investiga as principais concepções teóricas acerca das toxicomanias no campo da psicanálise e analisa seus percursos teóricos. Destaca os principais conceitos que embasam as teorias, apura as divergências e convergências e verifica a evolução destas a partir do surgimento de novas perspectivas e da influência do contexto social contemporâneo a elas. Para melhor compreensão do contexto no qual essas teorias foram elaboradas, foi feito um levantamento da história do uso de drogas e do tratamento dos toxicômanos ao longo da história. Em seguida, investigou-se as principais concepções teóricas no campo da psicanálise através de um mapeamento de obras de autores clássicos e contemporâneos. Destacou-se e analisou-se os principais conceitos-base para as teorias encontradas. Como resultado, identificouse alguns eixos teóricos, que partem do narcisismo, identificação, destrutividade, compulsão à repetição e relações objetais. Também observou-se variações no estatuto psicopatológico, classificado como sintoma, estrutura, quadro, dentre outros. Por fim, constata-se que, apesar das divergências existentes, o recurso aos tóxicos predomina enquanto uma tentativa de remediar uma angústia, ainda que tenha consequências nocivas.

\section{Palavras-chave}

Drogas; Álcool; Toxicomania; Adicção; Psicanálise. 


\section{Abstract}

Padilha, Júlia Nina; Winograd, Monah (Advisor); Klier Padilha Netto, Ney (Co-Advisor). Drug Addiction: theoretical path in Psychoanalysis field. Rio de Janeiro, 2020. 92p. Dissertação de mestrado - Departamento de Psicologia, Pontifícia Universidade Católica do Rio de Janeiro.

The use of psychoactive substances has always been present in society (in a recreational, therapeutic or religious way). The addiction to these substances, in turn, has been more and more present in the media and in political-social discussions that try to understand the phenomenon. Cultural, social, economic, pharmacological and psychological aspects must be considered when theories and treatment actions are proposed. This work investigates the main theoretical conceptions about drug addictions in the psychoanalysis field. It also analyzes their theoretical paths. It highlights the main concepts that underlie the theories, refines divergences and convergences, verifies their evolution from the emergence of new perspectives and verifies the influence of the social context to them. In order to understand the context in which these theories were elaborated, a survey of the history of drug use and treatment of drug addicts was made throughout history. Moreover, the main theoretical concepts in psychoanalysis were investigated through a bibliographical analysis of works in both classic and contemporary authors. The main basic concepts for the theories found were highlighted and analyzed. As a result, some theoretical biases were identified, from narcissism, identification, destructiveness, repetition compulsion and object relations, for instance. There were also variations in psychopathological status, classified as symptom, structure, condition, among others. Finally, it was noted that despite the disagreements, the use of toxic substances predominates as an attempt to relieve anguish, even if the psychotropic medication has harmful consequences.

\section{Keywords}

Drugs; Alcohol; Drug addiction; Addiction; Psychoanalysis. 


\section{Sumário}

1 Introdução $\quad 8$

2 O Uso de Drogas ao Longo da História $\quad 12$

2.1 Drogas e Religião 13

$\begin{array}{lll}2.2 & \text { Drogas e Medicina } & 15\end{array}$

2.3 A questão da proibição 16

$\begin{array}{lll}2.4 & \text { Brasil: da proibição ao tratamento } & 19\end{array}$

3 Panorama da Leitura Psicanalítica da Toxicomania 30

$\begin{array}{lll}3.1 \text { Freud } & 31\end{array}$

3.2 Pós-freudianos 36

4 Análise das Teorias à Luz dos Conceitos Psicanalíticos $\quad 54$

4.1 Do auto-erotismo ao narcisismo 54

4.1.1 Da Constituição do Eu às Toxicomanias 58

4.1.2 Melancolia e os tóxicos 61

4.2 Pulsão de Morte, Masoquismo, Destrutividade e as Toxicomanias 63

4.3 Da Necessidade ao Desejo, da Compulsão à Repetição ao Gozo 69

4.3.1 As Toxicomanias e a Articulação com a Compulsão à Repetição e ao Gozo 74

4.4 Objeto Droga e as Toxicomanias $\quad 77$

4.5 Considerações Sobre a Estrutura, o Quadro, o Sintoma 81

5 Considerações Finais $\quad 86$

$\begin{array}{ll}\text { Referências bibliográficas } & 92\end{array}$ 


\section{Introdução}

O uso de substâncias psicoativas sempre esteve presente na sociedade, seja em rituais religiosos ou terapêuticos seja em situações de comemoração e recreação. A dependência em relação a essas substâncias (também denominada toxicomania), por sua vez, tem ocupado cada vez mais espaço na mídia e em discussões político-sociais que buscam entender o fenômeno e desenvolver soluções para sanar os danos associados ao seu uso abusivo. Isto porque tanto a luta contra as substâncias quanto a luta pela cura do toxicômano tem sido marcada ao longo dos anos pelo insucesso.

São várias as leituras que discutem desde as propriedades tóxicas das substâncias às implicações da descriminalização, formas de tratamento, da responsabilidade de segurança ou saúde pública etc. Diante da diversidade de leituras e divergências acerca do fenômeno, tornou-se necessário buscar uma compreensão das toxicomanias em sua complexidade e as possibilidades de tratamento àqueles que são acometidos pelas suas consequências no que se refere aos aspectos psíquicos, corpóreos e sociais.

Questões culturais, sociais, econômicas, farmacológicas e psíquicas devem ser consideradas quando se propõem teorias e ações de tratamento para que o fenômeno não seja reduzido a uma ótica orgânica ou social. Para dispor de um trabalho de cunho psíquico, portanto, é legítimo e necessário que se leve em consideração o funcionamento inconsciente do aparelho mental em detrimento de uma visão organicista pautada apenas nas substâncias químicas em questão.

A partir da psicanálise, perspectiva teórico-clínica que considera os processos psíquicos inconscientes que ultrapassam o sujeito, buscamos interrogar o fenômeno da toxicomania e o que a passagem do uso recreativo para o uso abusivo diz do sujeito que se engaja nos tóxicos. Em dissonância com algumas propostas, a psicanálise não visa ao ajuste social, mas à implicação do sujeito pelo seu uso e às possibilidades de trabalho na clínica psicanalítica. Para dispor de uma prática clínica é necessário que o analista busque suporte na teoria para articular as questões que lhe são apresentadas.

Diante da complexidade do tema - por englobar vários aspectos e até mesmo pela dificuldade de distinguir o hábito de um vício -, questionamos se existe uma teoria única dentro da psicanálise que dá conta desse fenômeno ou 
se há várias teorias distintas que o abordam. Interrogamos também quais são essas teorias e como elas foram desenvolvidas, quais conceitos as basearam e como esse percurso teórico foi construído.

O objetivo deste trabalho é investigar as principais concepções teóricas acerca das toxicomanias no campo da psicanálise e analisar seus percursos. Buscamos destacar os principais conceitos que embasam essas teorias a fim de apurar suas divergências e convergências e de verificar a evolução destas a partir do surgimento de novos conceitos e perspectivas e também a partir da influência do contexto social contemporâneo a elas.

A relevância desta pesquisa está no âmbito teórico e social, pois aborda um tema que atinge direta ou indiretamente grande parte da população e que demanda dos profissionais de várias áreas subsídios para lidar com tal problemática. Enquanto pilar da prática clínica, é de fundamental importância que a teoria esteja bem definida e delimitada para que os profissionais saibam exatamente de que lugar determinada abordagem teórica enxerga as questões e como se propõe a trabalhá-las.

É pertinente não apenas conhecer o que dizem as teorias, mas também entender de que forma foram construídas. As percepções sobre as toxicomanias foram sendo desenvolvidas paralelamente à evolução da teoria psicanalítica e ambas foram e ainda são fruto de seu tempo e das mudanças de paradigma em relação à diversas questões.

As toxicomanias, de fato, exigem da psicanálise um modelo diferenciado de compreensão tanto em seus aspectos teóricos quanto em seus aspectos clínicos, pois parecem ultrapassar a lógica da neurose e do recalque. Supõe-se que as concepções e manejos questionem os moldes clássicos, porém, diante da infinidade de teorias e materiais, ainda há uma certa dificuldade em encontrar obras que esclareçam as principais vertentes e perspectivas que abordam esse tema, bem como suas construções teóricas e seus conceitos fundamentais.

Ademais, como teoria e clínica andam juntas, os profissionais que atuam nessa área podem partir de formulações teóricas já existentes e contribuir para a produção de conhecimento apoiados em suas experiências. Com base nessas compreensões, poderemos ter um norte em relação às possibilidades de trabalho com toxicômanos a partir da psicanálise, que propõe um trabalho sustentado na transferência para além do sujeito cidadão, levando em consideração a estrutura psíquica e o funcionamento do aparelho mental. Desta forma, profissionais e pacientes podem desfrutar dos avanços teóricos e clínicos em uma área ainda cercada por tabus e organicismos.

Freud (1915/2004) nos expõe que nem mesmo as ciências mais exatas começam sustentando-se em conceitos definidos e incontestáveis. Na descrição 
do material, já apresentamos ideias abstratas obtidas a partir de outras fontes e de novas experiências. As ideias não são escolhidas arbitrariamente, mas a partir da relação com o material empírico. As ideias são, sempre, indefinidas em certo grau, e apenas a posteriori que é possível formular os conceitos e modificálos gradualmente, visto que "o progresso do conhecimento não suporta que tais definições sejam rígidas" (p. 145).

Isto nos mostra que a teoria e a prática em psicanálise são indissociáveis. A pesquisa, nesse campo do saber, segue a mesma direção. As questões de pesquisa são articuladas à prática tanto em sua elaboração quanto nas dificuldades apresentadas na práxis. A teoria, por sua vez, não está no âmbito de um saber exato e acabado, mas, sim, em um movimento constante de desenvolvimento.

Apesar do uso de tóxicos - e consequentemente a adicção a eles - ser uma prática milenar, passou a ser problematizado especialmente no século $\mathrm{XX}$, com o fortalecimento do discurso médico e advento da psiquiatria. A psicanálise, por sua vez, surgiu no século XIX e sua produção sobre esse tema ainda era incipiente. Para compreendermos melhor em qual contexto as teorias psicanalíticas sobre as toxicomanias foram elaboradas e em quais concepções elas foram baseadas, elaboramos um levantamento da história do uso de drogas e do tratamento dos toxicômanos ao longo dos anos. Para tanto, utilizamos livros, artigos, manuais diagnósticos e documentos oficiais, tais como leis, decretos e políticas públicas.

Para investigarmos as principais concepções teóricas acerca das toxicomanias no campo da psicanálise realizamos um mapeamento teórico a partir do levantamento de obras de autores clássicos e contemporâneos como Freud (1897, 1898, 1900, 1905, 1912, 1930), Abraham (1908, 1910, 1916, 1924), Ferenczi (1911), Rosenfeld (1965), Melman (2008), Santiago (2017), Gurfinkel (2007, 2014), dentre outros. Também buscamos em sites acadêmicos, publicações a partir do termo "toxicomania" e de outros termos afins, como: "adicção", "drogadição", "compulsão", "dependência química", "uso abusivo de substâncias", "vício em drogas" e outros que se mostraram pertinentes.

Após o levantamento e estudo dessa literatura, destacamos os conceitos mais relevantes utilizados para embasá-la. Esses conceitos foram: autoerotismo, narcisismo, pulsões de morte, melancolia, masoquismo, compulsão à repetição e objeto. A fim de analisarmos essas teorias e verificarmos as semelhanças e divergências existentes, classificamo-las a partir das principais perspectivas existentes e as discutimos a partir dos conceitos priorizados.

A dissertação está organizada como segue. No segundo capítulo apresentamos o histórico do uso de drogas ao longo dos anos em diferentes civilizações 
e a sua relação com a cultura, a religião, a medicina etc. Também vemos como o surgimento da psiquiatria influenciou na mudança de paradigma em relação ao uso de drogas, bem como as questões sociais, econômicas e farmacológicas envolvidas no processo de proibição e criminalização do uso e comércio de drogas. Em relação ao Brasil, vemos como o uso de substâncias, que sempre fez parte de determinadas culturas e religiões, foi visto ao longo dos anos e como as leis de proibição e as políticas de tratamento foram desenvolvidas.

No terceiro capítulo apresentamos um panorama da leitura psicanalítica da toxicomania partindo do levantamento da obra freudiana no que diz respeito ao uso de drogas e vícios, e em seguida apresentamos um apanhado das principais teorias pós-freudianas acerca das toxicomanias. Vemos como as teorias foram sendo elaboradas e também de qual perspectiva especificamente os autores partiram. Alguns basearam-se em um ponto de vista pulsional, enquanto outros autores fundamentaram suas investigações nas relações objetais primitivas. Foram considerados por vários os aspectos pré-genitais envolvidos nas toxicomanias, bem como a possível relação com a melancolia e os ciclos maníaco-depressivos. As toxicomanias também foram classificadas por determinados autores como distúrbios ou patologias narcísicas, enquanto o caráter auto-destrutivo se mostra mais relevante em outras teorias.

No quarto capítulo fazemos uma análise das teorias apresentadas no terceiro capítulo à luz dos conceitos que se mostraram mais relevantes nestas. Também trazemos teorias contemporâneas a fim de traçar um paralelo comparativo com as teorias pós-freudianas expostas. Discutimos os conceitos de auto-erotismo, narcisismo, estádio do espelho e a relação desses conceitos com as teorias que abordam as toxicomanias a partir do narcisismo e de um viés da autoconservação. Citamos também o conceito de melancolia e as teorias que a relacionam com o recurso aos tóxicos. O conceito de pulsão de morte e masoquismo também foi discutido, bem como sua relação com as teorias que focam no caráter autodestrutivo existentes nas toxicomanias. Também discutimos a relação da compulsão à repetição com o uso de substâncias para lidar com a falta inerente ao sujeito. O conceito de objeto foi apresentado e trabalhado no sentido de discutir a relação que o usuário estabelece com o objeto droga. 


\section{2 \\ O Uso de Drogas ao Longo da História}

O uso de substâncias psicoativas é uma prática milenar que sempre esteve presente em diversas culturas e civilizações e conta com distintos modos de uso. Seja o uso ritualístico, terapêutico, medicinal ou recreativo, as drogas são "democráticas", pois são produtos presentes em diferentes classes sociais e econômicas (Ribeiro, 2009).

Ópio, cannabis, cogumelos, cactos, todas as formas de consumo do álcool, tabaco, café e chá são algumas dessas substâncias e plantas que têm uma importância se não igual, superior às plantas alimentícias, pois as drogas são alimentos espirituais, que consolam, anestesiam, estimulam, produzem êxtases místicos, prazer intenso e, por isso, instrumentos privilegiados de sociabilidade em rituais festivos, profanos ou religiosos. (Carneiro, 2005, p. 15-16)

As barreiras que distinguiam o que era alimento do que era remédio, magia e religião sempre foram muito fluidas e apenas o tempo e os costumes de cada cultura as definiriam. Apesar de a prática ser milenar, o uso de substâncias como um problema e a proibição são fatos relativamente recentes na história da humanidade, o que contribuiu para a criminalização e estigmatização presentes até os dias atuais. Para entendermos melhor um pouco sobre esse processo, vamos fazer um retorno histórico ao uso de substâncias na humanidade.

Carneiro (2005) nos explica que provavelmente a palavra droga deriva do termo holandês (droog) empregado, dos séculos XVI ao XVIII, em referência a um conjunto de substâncias utilizadas na alimentação, medicina, tinturaria ou mesmo para fins de prazer. As especiarias das índias orientais e ocidentais, riquezas que motivaram grandes navegações nos séculos XVI e XVII foram denominadas drogas por homens da época. A palavra se referia aos produtos de luxo e riquezas exóticas para consumo médico ou na alimentação. Ademais, não havia distinção clara entre alimento e droga no período colonial. No Brasil, as drogas mais importantes dos primeiros séculos coloniais eram o açúcar e o pau-brasil.

Antonio Escohotado, em seu livro "A brief history of drugs: from the stone age to the stoned age" (1996/1999) apresenta vários registros que apontam quetanto as sociedades greco-romanas quanto as egípcias possuíam conhecimento farmacológico e frequentemente consumiam vinho, ópio e ervas medicinais. Além desses, os gregos também consumiam cerveja, cannabis e 
plantas da família dos Solanáceos para fins ritualísticos, medicinais e recreativos. Para os romanos, o uso de ópio era considerado um hábito como qualquer outro e os imperadores tinham o hábito diário de usar bálsamos feitos com essa substância. Um registro de 2200 a.c. em tábua cuneiforme recomenda cerveja como uma espécie de tônico para mulheres lactantes. Cerveja e vinho, aliás, eram presentes em vários tratamentos presentes na farmacopeia do Egito antigo. Evidências de plantações de Papoula na Europa e nordeste africano datam mais de 3.000 a.c. Há também nessa região registros de fibras de cânhamo (obtida da cannabis para confecção de tecidos e papel) de 4.000 a.c.

A folha de coca, originária dos povos andinos, é representada em esculturas do século III a.c. que mostram seu povo mascando a folha estimulante. Outras substâncias estimulantes ricas em cafeína - como guaraná e mate - são maciçamente utilizadas na américa. A noz de areca (ou noz de betel) é um estimulante muito presente na cultura asiática. Chás estimulantes (como o de Efedra) já são utilizados na China há cinco milênios. A noz-de-cola na África, a planta Khat na Etiópia e Somália e o próprio café, originário da Arábia, compõem a extensa lista de substâncias estimulantes utilizadas no mundo inteiro por milênios.

Nos séculos XIX e XX a cannabis era uma mercadoria lucrativa nos Estados Unidos e uma planta importante para a cultura popular do nordeste do Brasil. A associação do consumo da erva à cultura negra contribuiu para a estigmatização do usuário e para o surgimento de políticas proibicionistas no país (Rosa, 2014).

Para além do uso recreativo já mencionado, veremos como as drogas concernem ao social, à medicina e de que forma foram vistas ao longo da história, ora como sagradas, ora como profanas. Também veremos de que forma as políticas proibicionistas e de tratamento aos dependentes foram desenvolvidas em diversos países, principalmente no Brasil.

\section{1}

\section{Drogas e Religião}

O uso de álcool e outras substâncias psicoativas sempre esteve fortemente presente em contextos religiosos. Como exemplo mais conhecido temos o uso do vinho pela igreja católica como representação do sangue de cristo durante a celebração da missa. Essa prática de ingestão do "sangue" ou do "corpo" de certo deus é um ato simbólico de sacrifício muito comum a muitas religiões, seja na África, Oceania, México ou Amazônia. No Shamanismo, a função do inebriamento está ligada a uma "jornada", a um estado de transe. As drogas (geralmente cogumelos) aguçavam os sentidos sem que o usuário 
perdesse a consciência ou a memória. Já o inebriamento de "possessão" mais comum na África - visava a perda total da consciência em rituais geralmente acompanhados por música e dança. Para estes eram utilizados álcool, tabaco e estramônio, erva conhecida como "zabumba" ou "figueira do diabo" (Escohotado, 1996/1999).

Se, por um lado, a igreja católica utilizava o vinho em seus rituais e fazia menção ao álcool na bíblia diversas vezes, por outro, endossava a inquisição que perseguia e queimava as pessoas acusadas de "bruxaria" na idade média, ou seja, qualquer prática que envolvesse uso de ervas ou substâncias de caráter medicinal, ou recreativo (no caso de substâncias com propriedades psicoativas). O simples uso de pomadas para aliviar a dor ou tratar qualquer ferimento era considerado feitiçaria e era passível de tortura e morte (Escohotado, 1996/1999).

A cannabis era utilizada na índia para auxiliar na meditação e para fins medicinais. Em 900 a.c. os mesopotâmios costumavam usar pedaços de haxixe em incensos nas cerimônias. O uso de Solanáceos (principalmente o tabaco) era muito presente na américa nos âmbitos religiosos, terapêuticos e recreativos. O uso de cogumelos alucinógenos também foi evidenciado na Europa, na Ásia e na região hoje conhecida como Guatemala, onde há registros de pedras esculpidas em formatos de cogumelos que datam do século $\mathrm{X}$ a.c.. No mesmo século há também registros da cultura Chavín na era précolombiana, que mostram esculturas com divindades em posse de peyote (cacto com propriedades psicoativas) (Escohotado, 1996/1999).

A manifestação religiosa brasileira "Santo Daime" - fundada na década de 30 e fruto de matrizes culturais indígenas, europeias e afro-brasileiras faz uso, em seus rituais, da bebida psicoativa ayahuasca, que além de estar presente em rituais, também tinha um papel importante no diagnóstico e cura de doenças. Essa manifestação religiosa marcada pelo sincretismo, que mistura cultura dos nativos e do colonizador, influenciada pelas religiões cristã, espírita, indígena e africanas, ganhou força a partir da decadência da borracha na região amazônica. Outras religiões ayahuasqueiras derivadas do "Santo Daime" foram criadas posteriormente, como a "Barquinha" e "União do Vegetal"(Labate \& Pacheco, 2005).

É interessante frisar que o Santo Daime fez uma apropriação da bebida psicoativa ayahuasca e gerou entusiasmo pelo seu viés do "autoconhecimento" - o que, de certa forma, ressalta uma distinção na visão da população sobre a forma do consumo de substâncias psicoativas. Fica evidente, não apenas no "Santo Daime", mas em diversas outras manifestações religiosas, uma distinção entre o consumo ritualístico de substâncias sagradas e naturais (que seriam 
mais legítimas) e o consumo urbano de drogas, considerada popularmente uma prática bem menos nobre.

\section{2}

Drogas e Medicina

Escohotado (1996/1999) nos mostra ainda que, com a forte ameaça dos inquisidores no século XII e resistência da população da época (com medo de retaliações), foi necessário que uma fronteira entre magia e farmacologia fosse bem desenvolvida, o que acarretou no surgimento das escolas e universidades de medicina nesse período. Os médicos da época receitavam (para os reis, a nobreza e o clero) plantas da família dos Solanáceos como ópio e cânhamo para ao tratamento de variadas queixas.

Paracelsus, famoso alquimista do século XVI, teve grande importância no estabelecimento de uma farmacologia que reunia ervas e preparos perseguidos na idade média com operações clássicas. Ele substituiu pomadas por pílulas e reformulou a apresentação dos medicamentos. Além disso, ele foi o responsável por criar o láudano (solução composta por álcool e ópio). No século XVII a morfina e o láudano já eram utilizados como anestésicos na guerra e para tratar outras substâncias e no século XVIII o extrato de papoula se tornou popular. A farmacologia ressurgiu entre a alquimia e a bruxaria e com ela uma nova indústria surgiu (Escohotado, 1996/1999). No século XIX, os opiáceos e a cocaína foram adotados como substâncias primordiais para o tratamento de inúmeros males físicos e psíquicos. Esse uso era sustentado pelo discurso médico e científico.

Figueiredo (2005) destaca que o remédio, que pode ser de origem vegetal, animal ou química, é uma intervenção externa ao corpo tanto no sentido de sua origem quanto no sentido de haver uma intermediação por quem o prescreve. O termo fármaco, de origem grega, faz referência ao que "faz bem" e ao que "faz mal". Toda medicação, de fato, é potencialmente benéfica ou maléfica. Tais qualidades dependerão do uso e da prescrição.

É notório que com o advento de uma nova ordem médica no século XIX, o uso de substâncias, que até então não era considerado um problema, passou por uma mudança de posição. Houve uma passagem da discussão moral e religiosa sobre o uso de drogas para os aspectos farmacológicos das substâncias, que agora eram atribuídas à dependência. A partir do reconhecimento da comunidade médica em relação aos malefícios do uso de substâncias houve uma intensificação das políticas proibicionistas. 


\section{3}

\section{A questão da proibição}

Antes de serem consideradas um problema de saúde, uma questão social ou mesmo antes de existirem leis que restringiam seu consumo e venda, as drogas já passavam por algumas proibições que iam de acordo com os valores de cada sociedade e sua visão sobre substâncias específicas. Rosa (2014) menciona que o consumo de vinho na Roma pré-industrial, por exemplo, era restrito a homens maiores de 30 anos e mulheres ou homens mais jovens que insistissem em beber o vinho poderiam ser executados. Na Rússia, beber café foi um crime punido com tortura e mutilação durante meio século, pois as autoridades reconheceram que o consumo diário de litros de café por pessoa causava grande excitação na população. O fumo de tabaco causava excomunhão entre católicos e amputação de membros na Turquia e Pérsia. Mesmo a erva mate, muito comum na região dos pampas, foi considerara uma bebida diabólica e apenas após as missões jesuítas no Paraguai que houve uma reformulação na narrativa sobre a origem da semente, que passou de semente trazida por satã à semente trazida por São Tomás, um dos apóstolos de Jesus (Escohotado, 1996/1999).

Fica bem evidente que o controle sobre as drogas sempre perpassou por interesses econômicos, políticos, culturais e morais. Temos como exemplo o esforço de países europeus cristãos em colonizar e eliminar o uso de drogas sagradas para os indígenas e substituí-las pelo vinho, que dentro da cultura cristã europeia tinha um papel fundamental (Carneiro, 2005). A história da humanidade é atravessada por eventos diretamente ligados ao controle dessas substâncias, contudo, o uso de drogas passou a ser considerado mesmo um problema social geral no século XIX na Europa e posteriormente nos Estados Unidos.

Em seu célebre livro "História da loucura na idade clássica", Foucault (1972/1978) destaca que antes, nos séculos XVII e XVIII, os alcoolistas e demais cidadãos acusados de perturbarem a ordem pública eram marginalizados e presos em hospitais. No século XIX, o alcoolismo era visto como uma fraqueza moral do indivíduo, um desvio de comportamento que poderia levar à loucura. Com o surgimento da psiquiatria, esses considerados "desvios de comportamento" passaram a ter um estatuto de ordem patológica. Os hospitais psiquiátricos surgiram como solução às doenças mentais e a exclusão social passou a se dar não mais de forma punitiva, mas como forma de tratamento. Ainda no século XIX, a ideia de incurabilidade das doenças mentais prevaleceu e a internação, que antes propunha tratamento e cura, passou a se dar sem essa perspectiva, sendo reforçada pela atribuição de periculosidade à imagem dos doentes mentais e prolongada por tempo indeterminado. 
Na segunda metade do século XIX, o uso abusivo de álcool passou a ser considerado uma "doença social", pois além de atingir organicamente o indivíduo que o consumia, o álcool em seu uso excessivo atingia também as esferas social e moral, pois o indivíduo ébrio não poderia cumprir suas funções na sociedade e teria sua produtividade afetada (Santos \& Verani, 2010).

Além de estar diretamente ligado à produtividade e ao cumprimento das funções sociais, o uso abusivo do álcool foi intimamente relacionado à criminalidade e ao desenvolvimento de demências. À vista disso, a sociedade burguesa, aliada aos interesses do capitalismo, logo exigiu medidas legais para a diminuição do uso do álcool.

No início do século XX, drogas como heroína e cocaína eram legalizadas e fortes fontes de renda para países europeus, que produziam e industrializavam principalmente os derivados do ópio. A conhecida "Guerra do Ópio" foi o embate entre o império chinês e a Grã-Bretanha (apoiada pela França) para impor o livre mercado e a legalização do ópio na China. Os chineses consumiam o ópio europeu (que era muito mais forte que o local) e o obtinham através da troca de seda, chás e especiarias. O império chinês proibiu o comércio de ópio com os estrangeiros na tentativa de preservar os preciosos recursos chineses. Posteriormente, o império proibiu também o cultivo na China, o que fortaleceu o contrabando e aumentou o descontentamento da população chinesa. Com o endurecimento das leis - que incluíam pena de morte tanto para o comércio como para o consumo - e após o império ter descartado toneladas de ópio, os britânicos declararam guerra ao império chinês em nome do livre comércio. A vitória europeia resultou na abertura de mais portos na China e a cobrança de taxas sobre a importação a serem pagas para a Grã-Bretanha (Escohotado, 1996/1999).

Os Estados Unidos, que não faziam parte do potente mercado do ópio, formaram a comissão do ópio em 1909 e em 1912 realizaram a "Conferência Internacional do Ópio", um evento que visava discutir o controle da fabricação, venda e importação dos opiáceos. Em 1922 a "Convenção Internacional do Ópio", fruto da conferência realizada dez anos antes, foi registrada na liga das nações (Rodrigues, 2005).

Vários episódios da história nos mostram que o proibicionismo esteve fortemente atrelado a fatores morais e econômicos. A conhecida Lei Seca, que vigorou nos Estados Unidos entre os anos de 1920 a 1933, foi fomentada pelas ligas anti-saloon e bancadas proibicionistas, que viam no álcool uma ameaça moral. A associação de determinadas substâncias com algumas nacionalidades e etnias também contribuiu para a estigmatização das substâncias. Como exemplo podemos citar a associação da maconha aos mexicanos, da cocaína 
aos negros, do ópio aos chineses e do álcool aos irlandeses.

Práticas sociais moralistas, controle social pelo governo e iniciativas diplomáticas internacionais fomentaram o proibicionismo no século XX. A proibição de psicoativos se tornou um discurso central entre as nações que discutiam o assunto em diversas conferências da ONU, como a "Convenção Única Sobre Entorpecentes" em 1961, a "Convenção Sobre Substâncias Psicotrópicas" em 1971 e a "Convenção Contra o Tráfico Ilícito de Entorpecentes e Substâncias Psicotrópicas" em 1988. A cada convenção foi elaborada uma lista atualizada de substâncias a serem controladas, e o critério principal para a classificação das substâncias era o fator terapêutico para a medicina ${ }^{1}$.

Os tratos internacionais são incorporados pelos Estados signatários e viram leis. A políticas proibicionistas passam a nortear os estados e departamentos antidrogas são criados. Movimentos repressivos em relação aos usuários e traficantes ganham cada vez mais força e uma guerra internacional começa a ser travada. O presidente dos Estados Unidos Richard Nixon declarou guerra às drogas em 1971, sustentando a narrativa de que os países produtores (países subdesenvolvidos) eram agressores e os países consumidores (desenvolvidos) eram vítimas.

Ao passo que as políticas proibicionistas se fortaleciam, o tráfico também se fortalecia em um nível industrial. Na década de 80, o presidente americano Ronald Reagan, de modo similar a Nixon na década anterior, trava uma guerra aos países produtores e começa a intervir em países da américa latina. Em tempos de guerra fria, a associação do narcotráfico à guerrilha de esquerda na américa latina serviu como uma estratégia dos EUA para fortalecer a guerra ao terror, ou ao "narcoterror". Nos anos 90, houve um aumento do consumo e da produção de drogas no Brasil, com o refino de cocaína na Amazônia e plantações de maconha no nordeste do país. O Narcotráfico no Brasil caminhou junto com a repressão de acordo com os contornos internacionais proibicionistas. Essa questão permeia o país até os dias atuais (Rodrigues, 2005).

No Brasil, atribui-se às drogas ilícitas e aos usuários características negativas e estereotipadas. Problemas estruturais da sociedade como desigualdade social, deficiências dos sistemas público de educação, saúde e segurança não são levados em consideração para a análise das questões do país, que muitas vezes são justificados com o tráfico e uso ilegal de substâncias. Essas justificativas sustentam medidas repressivas, que por sua vez, mantêm o sistema político-econômico vigente.

\footnotetext{
${ }^{1}$ Informações do Escritório da ONU sobre Drogas e Crime (UNODC) disponíveis em: https://www.unodc.org/lpo-brazil/pt/drogas/marco-legal.html
} 
O reducionismo dessa esteriotipação ao encobrir alguns dos reais problemas estruturais da sociedade criando um inimigo imaginário, que tem sua utilidade na manutenção do status quo, acaba por aumentar a marginalização dos usuários assim como leva à cristalização uma "subcultura da droga" de pouca permeabilidade a agentes de saúde ou a representantes de qualquer tipo de discurso oficial. E, como uma profecia que cumpre a si mesma, isso leva à criação de novas ameaças à ordem e à saúde nessa sociedade (MacRae, 2007 p.1)

A escolha de expor a trajetória da relação humana com as drogas ao longo da história não foi despropositada. Ao entendermos como as drogas sempre estiveram presentes nas civilizações, seja como alimento, objeto recreativo, instrumento religioso, medicamento ou instrumento do diabo, podemos compreender os significados e significantes atribuídos às substâncias. Estes conduziram as leis, a forma como nos relacionamos com elas e, por fim, como enxergamos e trabalhamos a relação do sujeito adicto com seu objeto droga. Vejamos mais especificamente como ocorreu esse processo no Brasil.

\section{4}

\section{Brasil: da proibição ao tratamento}

Registros das boticas dos séculos XVIII e XIX no Brasil indicam que os boticários manipulavam e receitavam drogas, além de realizarem consultas e diagnósticos em toda a população. Essas drogas eram manipuladas a partir de extratos, ácidos, éteres, óleos, pós, dentre outras substâncias. As prescrições dos remédios vinham acompanhadas muitas vezes de doses de aguardente e vinho (Figueiredo, 2005). Até o final do século XIX o vinho era usado como anti-séptico na lavagem de ferimentos e para tornar a água potável (Lopes \& Lima, 2005).

O cauim era uma bebida alcóolica utilizada em rituais indígenas, a aguardente foi associada à revolta escrava, remédios de boticários e curandeiros, bem como as "garrafadas" faziam parte do dia-a-dia dos brasileiros e os rituais com ayahuasca na religião "Santo Daime" mostram que no Brasil sempre houve uso de drogas, que ia da cura ao crime, religião, folclore e medicina (Carneiro, 2005). As "garrafadas" (misturas feitas por curandeiros a partir de raízes, folhas, frutos e cascas cozidos e depois infusionados com cachaça ou vinho branco), por exemplo, ainda são muito utilizadas em algumas regiões e são patrimônio cultural brasileiro, fazendo parte da identidade nacional, principalmente no sertão brasileiro (Ribeiro, 2005).

Na década de 1830, no primeiro império, a maconha chegou a ser proibida em decorrência não de suas propriedades psicoativas, mas como uma forma de controle de práticas associadas aos negros e mestiços. A droga, antes mesmo 
de ser proibida, sempre foi associada às classes baixas, à delinquência e à população negra.

Tradicionalmente, o uso dessa planta para diversão era visto como proveniente da África e associado quase exclusivamente à população pobre, negra e indígena, principalmente das regiões Nordeste e Norte do país. Após a abolição da escravatura, esses contingentes populacionais, mal integrados à vida socioeconômica do país, causavam temor às elites. Nessa época, desenvolveu-se um discurso voltado para a "melhoria da raça brasileira", buscando uma maior integração com a cultura europeia e um "embranquecimento" da população (Brasil, 2017, p. 6).

A propósito, várias práticas culturais de origem africana tais como o candomblé, capoeira e o próprio uso da maconha eram desqualificadas e consideradas causadoras de doenças mentais. No início do século XX, as primeiras leis para tratar de problemas relacionados ao vício eram voltadas aos "vícios elegantes" (ópio, morfina e cocaína), que eram substâncias usadas por jovens brancos de classes altas. Os problemas decorrentes do "ópio de pobre" (maconha) para a saúde da população negra não interessavam aos médicos e legisladores. Ações repressivas, por outro lado, eram frequentes e afetavam a população negra e mestiça principalmente nas regiões Norte e Nordeste (Brasil, 2017).

Ao discutir sobre a medicalização do uso de drogas no Brasil e questões institucionais envolvidas, Fiore (2005) pontua que a preocupação e a discussão sobre controle de drogas não eram existentes no Brasil até o início do século XX. O consumo de álcool, entretanto, já havia se mostrado uma preocupação, mas não por sua composição, mas por uma questão moral. Os "bêbados" e "degenerados" eram considerados moralmente defeituosos. O álcool em si passou a ser considerado um problema apenas no final do século XIX (Fiore, 2005).

No século XIX, a psiquiatria levantava a questão:

[...] o álcool seria responsável pela produção dos sintomas de desordem mental ou a perturbação já existiria anteriormente, sob forma latente, e, nesse caso, o álcool funcionaria como um fator desencadeador de uma patologia já existente? (Santos \& Verani, 2010, p. 402).

Com a consolidação da medicina como um saber científico e legitimado, lhe foram concedidos poderes políticos tais como a comprovação científica dos efeitos terapêuticos de algumas drogas e quais faziam "mal" e "bem". Consequentemente, ficou a cargo da área opinar sobre quais substâncias deveriam ser lícitas, ilícitas e restritas ao poder médico (Fiore, 2005).

Em 1914, o presidente Hermes da Fonseca assina o decreto n⿳0口2.861, que, em adesão ao que fora discutido na "Conferência Internacional do Ópio", proibia a venda de ópio, morfina, heroína e cocaína no país. Em 1921, uma comissão 
formada por médicos, juristas e autoridades policias se reuniu no intuito de modificar o código penal no que dizia respeito ao uso de "entorpecentes". A venda de ópio e derivados passa a ser punida com prisão e a embriaguez que implicasse em desordem pública era punida com internação compulsória. Devido ao grande contingente de alcoolistas internados em hospitais psiquiátricos, foram criados "sanatórios para toxicômanos" para melhorar o problema da superlotação e reinternações por "embriaguez". Os alcoolistas eram internados a pedidos da família ou de um juiz. Em 1932, a maconha entrou na lista das substâncias e o porte passou a ser crime passível de prisão e internação. A essa altura, o uso de substância já era percebido também como um problema de saúde, ainda que as medidas ainda possuíssem um caráter repressivo e criminalizante que propunham exclusão dos usuários do convívio social baseadas na defesa da ordem social (Fiore, 2005).

Em 1936, foi criada a Comissão Nacional de Fiscalização de Entorpecentes (CNFE), que tinha como função legislar sobre o tema. Em 1938, o CNFE elaborou a Lei de Fiscalização de Entorpecentes (Decreto-lei n. 891/1938). Foi fixada a mesma pena para venda, porte ou uso de drogas. Outra novidade na lei foi a notificação obrigatória da toxicomania às autoridades e proibição do tratamento domiciliar da então considerada doença (Fiore, 2005).

Nesta década de 1930, a comunidade voluntária "Alcoólicos Anônimos" (AA) surgiu no intuito de reunir pessoas dependentes de álcool a partir da proposta de abstinência total. Os dependentes compartilham suas experiências e se entreajudam na intenção de permanecerem sóbrios. Baseado no AA, o grupo "Narcóticos Anônimos" (NA) surgiu na década de 1950 com os mesmos fundamentos e métodos do AA, só que voltado para usuários de outras substâncias.

Após as diversas convenções internacionais sobre o uso de "entorpecentes" e tratados decorrentes dessas convenções, foi implementada no Brasil a Lei de Tóxicos (Lei n. 6368) em 1976, que criou o Sistema Nacional de Prevenção, Fiscalização e Repressão de Entorpecentes (SNPFRE) e o Conselho Federal de Entorpecentes (CONFEN). A lei extingue a internação obrigatória e modifica a penalidade, separando porte, venda e consumo. As decisões sobre quais substâncias seriam proibidas fica então a cargo do Ministério da Saúde (Fiore, 2005).

$\mathrm{Na}$ década de 1970, o uso de drogas passou a ser considerado não apenas pela concepção jurídico-penal, mas também pela perspectiva médicopsiquiátrica. O usuário de drogas passou a ser visto como doente e os hospitais psiquiátricos passaram a ter a função não apenas de punir, mas de salvar e recuperar esses indivíduos. O tratamento era realizado em regime hospitalar e 
extra-hospitalar e seguia o modelo excludente e asilar. Às redes de serviço de saúde, foram atribuídas medidas referentes ao tratamento de dependentes de substâncias, como a adaptação de unidades de saúde para essa finalidade ou construção de estabelecimentos próprios para este fim. Na mesma década houve a instalação de comunidades terapêuticas no país, havendo maior expansão desses dispositivos na década de 1990. Esses dispositivos propagaram-se sem nenhum tipo de fiscalização ou regulamentação (Machado, 2006).

Vale ressaltar que a reforma psiquiátrica no Brasil influenciou diretamente na assistência aos dependentes de álcool e outras drogas. A reforma visava modificar a perspectiva de atenção e tratamento dispensados aos pacientes na área de saúde mental. A crise do modelo manicomial e os crescentes esforços de movimentos sociais em prol dos direitos dos pacientes psiquiátricos culminou nesse processo social e político, marcado pela desinstitucionalização. Esse processo teve grande repercussão e impulsionou a implementação de uma rede de cuidados que pudesse substituir os hospitais psiquiátricos (Brasil, 2005).

Em 1986 foi criado o documento "Proposta para o Programa Nacional de Prevenção, Recuperação e Ressocialização de Usuários de Drogas e Bebidas Alcoólicas", que, além de afirmar o alto custo proveniente dos benefícios previdenciários e utilização dos serviços de saúde por alcoolistas, também propunha uma nova forma de atendimento a dependentes de drogas e álcool, criticando o modelo hospitalocêntrico e a abordagem medicamentosa predominante.

Produto do movimento sanitário e de reivindicações em vários eventos, o Sistema Único de Saúde (SUS) foi instituído pela Constituição Federal de 1988, em seu artigo 196, que define a saúde como um "direito de todos e dever do Estado". O sistema surgiu com a função de organizar e regular as ações e serviços de saúde em todo o país.

Em 1988 foi estabelecido o "Programa Nacional de Controle dos Problemas Relacionados com o Consumo de Álcool" (PRONAL). O programa propunha uma rede de tratamento composta principalmente por serviços de atenção primária, incluindo medidas restritivas à oferta do álcool, apoio ao desenvolvimento de pesquisas relacionadas à temática do álcool, criação de um sistema de registro e de dados relacionados ao uso do álcool e mudanças legislativas no que diz respeito à venda, consumo e veiculação de propagandas relacionadas ao álcool. O programa não chegou a ser implementado devido a fatores como a falta de articulação do programa com a lógica do SUS e indefinição de financiamento (Machado, 2006).

A política do Ministério de Saúde para a Saúde Mental começa a ganhar contornos mais definidos na década de 1990, juntamente com o progresso da 
Reforma Psiquiátrica no Brasil. Passam a entrar em vigor as primeiras normas federais regulamentando a implantação de serviços de atenção diária e as primeiras normas para fiscalização e classificação dos hospitais psiquiátricos. Neste período, os CAPS e Núcleos de Atenção Psicossocial (NAPS) se expandiram pelo país, chegando a 208 CAPS no Brasil, mas ainda não havia sido instituído o financiamento do Ministério da Saúde e os hospitais psiquiátricos recebiam mais de $90 \%$ da verba destinada à Saúde Mental (Brasil, 2005).

Em 1998, o Decreto n. 2.632 criou a Secretaria Nacional Antidrogas (SENAD) e o Conselho Nacional Antidrogas (CONAD), que juntos, atuam no sentido de "planejar, coordenar, supervisionar e controlar as atividades de prevenção e repressão ao tráfico ilícito, uso indevido e produção não autorizada de substâncias entorpecentes e drogas que causem dependência física ou psíquica, e a atividade de recuperação de dependentes" (Brasil, 1998, p. 2).

Em 1999 foi criado o documento "Proposta de Normalização dos Serviços de Atenção aos Transtornos por Uso e Abuso de Substâncias Psicoativas" que propunha a inclusão de alguns procedimentos específicos no SUS da área de álcool e drogas. A realização desse documento se deu através da articulação entre a Secretaria Nacional de Políticas Antidrogas (SENAD) e Ministério da Saúde, mas não acarretou em nenhuma modificação na assistência prestada pelo SUS a essa população (Machado, 2006).

Em 2001,

[...] a Lei Federal 10.216 redireciona a assistência em saúde mental, privilegiando o oferecimento de tratamento em serviços de base comunitária, dispõe sobre a proteção e os direitos das pessoas com transtornos mentais". (...) É no contexto da promulgação da lei 10.216 e da realização da III Conferência Nacional de Saúde Mental, que a política de saúde mental do governo federal, alinhada com as diretrizes da Reforma Psiquiátrica, passa a consolidar-se como política oficial do SUS e ganha maior sustentação e visibilidade (Brasil, 2005, pp. 8-9).

Nesse contexto, foram criadas pelo Ministério da Saúde linhas de financiamento para os serviços substitutivos ao hospital psiquiátrico, bem como programas e políticas voltados para a Saúde Mental, a partir dos quais houve uma transição do modelo de assistência centrado no hospital psiquiátrico para um modelo de atenção comunitário, que inclui desde a atenção básica à atenção terciária, centros comunitários, familiares e usuários. Finalmente, com a construção de uma rede de atenção à Saúde Mental juntamente com a fiscalização e redução progressiva de leitos psiquiátricos, consolidou-se a reforma psiquiátrica no Brasil (Brasil, 2005).

Pelo descrito até aqui, podemos afirmar que até os anos 2000, não havia uma política nacional no âmbito da saúde pública voltada para tratamento 
a usuários de álcool e outras drogas e os serviços eram restringidos a poucos ambulatórios e hospitais. As estratégias traçadas para este fim consistiam em redução da oferta de drogas - com ação da justiça, da segurança e da defesa - e redução da demanda, que consistia em internar o indivíduo para que ele ficasse longe da substância da qual dependia (Brasil, 2003).

No ano de 2002, após a III Conferência Nacional de Saúde Mental e diante da "necessidade de definição de estratégias específicas para a construção de uma rede de assistência aos usuários de álcool e outras drogas, com ênfase na reabilitação e reinserção social" (Brasil, 2005, p. 42), o Ministério da Saúde implementou o Programa Nacional de Atenção Comunitária Integrada aos Usuários de Álcool e outras Drogas, no intuito de reconhecer a questão do uso prejudicial de drogas como um problema de saúde pública e construir uma política de atenção aos usuários de álcool e outras drogas

[...] tendo como estratégia a ampliação do acesso ao tratamento, a compreensão integral e dinâmica do problema, a promoção dos direitos e a abordagem de redução de danos. (...) O Programa organiza as ações de promoção, prevenção, proteção à saúde e educação das pessoas que fazem uso prejudicial de álcool e outras drogas e estabelece uma rede estratégica de serviços extra-hospitalares para esta clientela, articulada à rede de atenção psicossocial e fundada na abordagem de redução de danos (Brasil, 2005, p.41-43).

O documento dessa Política do Ministério da Saúde propõe como diretrizes: designação da questão do uso de álcool e outras drogas como de saúde pública; adoção do paradigma de redução de danos nas ações de prevenção e tratamento; desestigmatização do usuário de álcool/drogas como doente a ser internado ou preso; viabilização de uma atenção integrada no SUS e ações para reduzir os danos causados à saúde em decorrência do uso de álcool e outras drogas no país (Machado, 2006).

A não priorização, por parte do Ministério da Saúde, de uma política de saúde integral ao usuário de álcool e outras drogas acarretou, ao longo dos anos, consequências diretas ao SUS de cunho econômico e social, seja pelos custos ou pelo insucesso da tentativa de redução do uso de drogas por outras áreas governamentais.

Entendeu-se que uma política que visa a prevenção, o tratamento e a educação para o uso de álcool e outras drogas necessitava estar interligada a outros programas do Ministério da Saúde, a outros Ministérios e a outros setores da sociedade em geral dentro de uma perspectiva da Saúde Pública, de modo que a abstinência não seja considerada a única meta viável e possível (Brasil, 2003).

A visada do governo federal para o enfrentamento ao uso abusivo de álcool e outras drogas é a criação dos CAPSad, de onde se espera um papel 
estratégico na rede de cuidados tanto no sentido de cumprir com suas funções na assistência direta quanto no papel de regulador da rede de serviços de saúde e articulador de recursos em outras redes (sócio-sanitárias, jurídicas, escolas, empresas, etc) (Brasil, 2004).

Trata-se de um serviço público de saúde que oferece tratamento diário aos usuários de álcool e outras drogas e atua com uma proposta de acompanhamento clínico e reinserção social através do acesso ao exercício dos direitos civis, trabalho, lazer e fortalecimento dos laços familiares e comunitários. Além dos CAPSad, outros dispositivos tiveram sua implementação incentivada em vários estados e municípios a partir desse novo programa. Ações no âmbito da atenção primária, vínculo com redes de suporte social e implementação da rede hospitalar de retaguarda aos usuários de álcool e outras drogas nos Hospitais Gerais compõem essa nova perspectiva (Brasil, 2005).

A lei dos tóxicos de 1976, até então vigente, foi revogada pela Lei n. 11.343 em 2006, que institui o Sistema Nacional de Políticas Públicas sobre Drogas (SISNAD). A partir de então, começa a haver uma mudança na perspectiva do Estado em relação às questões associadas ao uso de substâncias psicotrópicas. Continuam presentes medidas relacionadas ao uso, produção e tráfico de substâncias, porém, há um enfoque na saúde dos usuários e são oferecidas novas formas de tratamento que visam a reinserção social. A lei também traz uma distinção clara entre o grupo de usuários e dependentes e o de traficantes, além de não descriminalizar qualquer tipo de droga. O porte continua a ser considerado crime, ainda que os usuários não sejam mais submetidos à pena privativa de liberdade e sim a medidas socioeducativas. O tratamento deixa de ser obrigatório (Brasil, 2010a).

Em 2007 a Política Nacional sobre o Álcool foi aprovada e, com ela, várias "medidas para reduzir e prevenir os danos à saúde e à vida, bem como as situações de violência e criminalidade associadas ao uso prejudicial de bebidas alcoólicas" (Brasil, 2010a, p. 75). As propagandas de bebidas passam a ser restringidas, a venda de bebidas alcoólicas em rodovias passa a ser proibida e é estipulada uma margem de tolerância de álcool no sangue para condutores de veículos, que posteriormente foi reduzida a zero.

Em 2010 foi instituído o Plano Integrado de Enfrentamento ao Crack e outras Drogas que visava a prevenção do uso, o tratamento e a reinserção social de usuários e o enfrentamento do tráfico de crack e outras drogas ilícitas (Brasil, 2010b). O programa "Crack, é possível vencer" surgiu em 2011 como medida do plano de enfrentamento ao crack e outras drogas e articulado com a Rede de atenção Psicossocial para pessoas com sofrimento ou transtorno mental e com necessidades decorrentes do uso de crack, álcool e outras drogas. As medidas 
tomadas a partir da política sobre o álcool e sobre o crack demonstram o caráter de enfrentamento das duas substâncias a fim de reduzir as consequências causadas pelo uso destas.

É interessante observar a mudança na perspectiva em relação às drogas e aos usuários no decorrer da história do Brasil. As drogas, que assim como em qualquer outro lugar, sempre estiveram presentes em contextos medicinais, ritualísticos e recreativos passam a ser associadas aos negros e pobres (no caso da maconha) e ganham maior depreciação com a adesão aos tratados internacionais, que, apoiados pela medicina moderna, definem quais substâncias são úteis ou não. A redemocratização do país, o surgimento do SUS e a reforma psiquiátrica são acontecimentos históricos que afetam diretamente nessa mudança de perspectiva. O tratamento, que por anos teve caráter repressivo e compulsório passa a ser substituído por programas e políticas públicas que prezam por uma rede de cuidados de caráter comunitário que substitui o modelo hospitalocêntrico. Além das mudanças no modelo de assistência aos usuários, um dos objetivos das novas políticas é desestigmatizar os usuários de substâncias, circunstância sustentada durante muitos anos pelas próprias ações do governo.

A portaria $n^{\circ} 3.088$ institui, no âmbito do SUS, no ano de 2011, a Rede de Atenção Psicossocial (RAPS) para pessoas com sofrimento ou transtorno mental e com necessidades decorrentes do uso prejudicial de drogas (Brasil, 2011). A rede propõe criação, ampliação e articulação de pontos de atenção à saúde para pessoas na supracitada situação. São componentes da rede: Atenção básica (inclui "Estratégia Saúde da Família", "Núcleo de Apoio à Saúde da Família", "Equipe de Consultório na Rua" e "Centro de Convivência e Cultura"); Atenção Psicossocial Estratégica (inclui os "CAPS"); Atenção Residencial de Caráter Transitório (inclui "Unidades de Acolhimento" e "Serviços de Atenção em Regime Residencial (comunidades terapêuticas)"; Atenção hospitalar (inclui "Serviço de Atendimento Móvel de Urgência - SAMU", "Unidade de Pronto Atendimento - UPA" e "Serviço Hospitalar ou Enfermaria Especializada em Hospital Geral"); Estratégia de Desinstitucionalização (inclui "Serviço Residencial Terapêutico" e "Programa de Volta para a Casa") e Estratégia de Reabilitação Psicossocial (com as "Estratégias de Reabilitação Psicossocial") (Brasil, 2014).

Ainda que reconheçamos a vigência de diversos programas propostos nos anos 2000, cabe advertir que o sujeito em questão, o cliente, o usuário, continua sendo tratado como coadjuvante do sintoma, do vício. No que diz respeito à dependência das drogas, a heterogeneidade predominante - pois as pessoas são afetadas de diferentes maneiras, por diferentes razões, em diferentes contextos e circunstâncias - parece ser desprezada. Muitos usuários de drogas evadem 
ou sequer procuram os serviços de saúde existentes, pois não compartilham da expectativa e desejo de abstinência dos profissionais de saúde e por não se sentirem acolhidos em suas diferenças.

A partir da constatação do insucesso de algumas tentativas de implantação de programas de prevenção, educação e tratamento no que diz respeito ao uso de drogas - pautadas na lógica da abstinência -, buscou-se novas estratégias de contato e de vínculo com o usuário e seus familiares a fim de reconhecê-lo em suas características e necessidades. Essa nova perspectiva de reconhecimento de diferentes estratégias como complementares surgiu como aposta para a construção de uma política de saúde coerente, eficaz e efetiva (Brasil, 2003).

O conceito de redução de danos, originalmente apresentado como proposta para prevenção de doenças transmissíveis e adotado pelo Ministério da Saúde em 1994, vem sendo utilizado de forma norteadora na política do Ministério da Saúde para álcool e outras drogas. As ações de redução de danos que focavam a prevenção e diagnóstico do HIV deram, de certa forma, visibilidade aos usuários de drogas injetáveis no SUS, o que promoveu a organização de funcionários e usuários e trouxe significativas contribuições para a revisão de leis em vigor e compartilhamento de saberes técnicos e populares. Essa visibilidade possibilitou o desenvolvimento de estratégias para abordagem dos problemas de saúde dos usuários de drogas (Brasil, 2003).

Nesse paradigma, a redução de danos - que, em 2004, passou a ser estratégia oficial na Política de Atenção Integral a Usuários de Álcool e outras Drogas - visa "reduzir os danos causados pelo abuso de drogas lícitas e ilícitas, resgatando o usuário em seu papel auto regulador, sem a exigência imediata e automática da abstinência, e incentivando-o à mobilização social" (Brasil, 2005, p. 44).

A estratégia de redução de danos propõe reconhecer cada usuário de forma singular e traçar, junto a ele, estratégias voltadas para a defesa de sua vida. Essa estratégia tem por fim práticas mais acolhedoras às demandas de cada situação e cada usuário e visa estimular sua participação e engajamento a partir da oferta do possível e necessário para cada um. Essa abordagem visa não só o tratamento, mas a construção de uma rede de atenção aos usuários de álcool e outras drogas e a prevenção das consequências negativas do uso abusivo dessas substâncias (Brasil, 2005).

No ano de 2003, o Ministério da Saúde implementou a Política Nacional de Humanização (PNH) HumanizaSUS a fim de consolidar redes, vínculos e a co-responsabilização entre usuários, trabalhadores e gestores. Para isso, estabeleceu ferramentas e dispositivos que pretendem articular ações, saberes 
e práticas em prol de uma atenção integral e humanizada.

A clínica ampliada é uma proposta que visa a não-redução do paciente ao recorte diagnóstico ou burocrático, mas a valorização da multicausalidade dos problemas de saúde e complexidade dos sujeitos. Diante dessa perspectiva, a clínica ampliada propõe a valorização dos saberes distintos e ampliação destes através do trabalho em equipe para lidar com usuários enquanto sujeitos, dialogando com estes e estendendo a participação e autonomia no projeto terapêutico (Brasil, 2008).

A questão das drogas sempre foi tratada a partir de duas abordagens predominantes: a abordagem moral e criminal, que pune o usuário, e a abordagem médica, que trata o uso como doença e proíbe o acesso a esse problema. Vários avanços foram realizados ao longo dos anos, como o surgimento do SUS, da Rede de atenção à Saúde Mental, dos dispositivos CAPS e articulação com a atenção primária. O desenvolvimento de uma política de saúde mental e propostas mais estruturadas que incluem uma abordagem multidisciplinar que visam a prevenção, atenção e reinserção dos usuários traduzem os esforços desse novo paradigma. Diversas mudanças na legislação (como a que distingue o consumo pessoal de tráfico) também foram realizadas.

Pudemos observar que o uso de drogas sempre esteve presente na humanidade e que a tanto as formas de consumo como as leis que as proíbem foram e ainda são definidas pelos valores culturais de cada civilização. A dependência às substâncias, que a princípio fora considerada um problema moral passou a ser considerada um problema de saúde e segurança. Foram criadas leis que proíbem o consumo e venda de substâncias e algumas medidas no âmbito da saúde foram tomadas no intuito de entender o fenômeno e tratar as pessoas acometidas pela dependência. As definições de droga, dependência e origem desta ainda são um pouco controversas.

O uso de drogas, considerado pela medicina moderna uma doença, mostra um certo juízo de valor por parte da comunidade médica, pois além da substância em questão, é importante analisar as modalidades de uso (abusivo, moderado ou raro). A questão é: onde termina o costume e onde começa o vício? Vícios são maus hábitos e hábitos são bons costumes? Como fazer essa distinção? Sobre essa questão, Carneiro (2005) faz a seguinte reflexão: Ao comprarmos drogas e alimentos, o que as diferencia é o regime jurídico e político que regula o direito à livre escolha. (...) Os alimentos e as drogas sempre se constituíram como os principais produtos da cultura material, em paradigmas da relação de si para consigo, ou seja, nos mecanismos auto-regulatórios da obtenção do prazer. São o terreno onde se desenvolve e se educa à vontade no exercício da autocontenção (p. 21).

De acordo com a Organização Mundial da Saúde (OMS), droga é qualquer substância não produzida pelo organismo que, ao ser consumida, afeta 
as funções de um ser vivo. A organização também considera doença o vício a qualquer substância (lícita ou ilícita). O CID 10, (Classificação Estatística Internacional de Doenças e Problemas Relacionados à Saúde estabelecidas pela OMS) classifica várias doenças relacionadas ao uso de droga, como transtornos mentais e comportamentais decorrentes do uso de álcool, opiáceos, canabinóides, alucinógenos e demais substâncias (OMS, 2001).

O DSM - V (Manual Diagnóstico e Estatístico de Transtornos Mentais), feito pela Associação Americana de Psiquiatria, também classifica transtornos relacionados a substâncias e categoriza dez classes de drogas, entre estimulantes, sedativos, alucinógenos, tabaco e outras (APA, 2008/2014). A distinção entre "abuso" e "dependência" de substâncias, existente na versão anterior do manual foi retirada e atualmente a classificação está englobada em "transtorno por uso de substâncias". Esse transtorno possui como principal característica o conjunto de sintomas comportamentais, fisiológicos e cognitivos que indicam o uso contínuo. O primeiro grupo de critérios relaciona-se ao baixo controle sobre o uso da substância. O segundo grupo de critérios está relacionado ao prejuízo social (falha ou abandono de atividades importantes). O terceiro grupo é sobre o uso arriscado da substância (risco à integridade física e existência de problema físico ou psicológico persistente) e o último grupo de critérios são os farmacológicos (tolerância e abstinência).

O DSM-5 exige dois ou mais critérios para o diagnóstico de Transtorno por Uso de Substância e a gravidade do quadro passou a ser classificada de acordo com o número de critérios preenchidos: dois ou três critérios indicam um transtorno leve, quatro ou cinco indicam um distúrbio moderado e seis ou mais critérios indicam um transtorno grave (Araújo \& Lotufo Neto, 2014).

É interessante frisar que o DSM V incluiu o "Transtorno de Jogo" dentre os "Transtornos relacionados a substâncias e Adição", pois as evidências apontavam que os efeitos dos jogos de azar atuavam sobre o sistema de recompensa de forma semelhante aos efeitos do uso de drogas. Sobre o uso de substâncias, o manual ainda afirma que

Indivíduos com baixo nível de autocontrole, o que pode ser reflexo de deficiências nos mecanismos cerebrais de inibição, podem ser particularmente predispostos a desenvolver transtornos por uso de substância, sugerindo que, no caso de determinadas pessoas, a origem dos transtornos por uso de substância pode ser observada em seus comportamentos muito antes do início do uso atual de substância propriamente dito (APA, 2008/2014, p. 481).

Isso evidencia o fato de que o vício e a dependência não podem ser explicados apenas pela composição química aditiva das drogas. E nos levanta a questão: Afinal, o que é toxicomania? Abordaremos a questão sob a ótica da Psicanálise nos próximos capítulos. 


\section{Panorama da Leitura Psicanalítica da Toxicomania}

Como vimos anteriormente, a partir da modernidade a questão das drogas passou a ser constante motivo de preocupação na sociedade pelos seus efeitos devastadores nos âmbitos familiar, político, de saúde e segurança. Além da perspectiva do objeto mau que precisa ser combatido, outras perspectivas surgiram a fim de entender o fenômeno, classificá-lo e tratá-lo.

A relação do uso de drogas com o saber médico foi considerada por Gurfinkel (2014) um "feitiço que pode voltar-se contra o feiticeiro" (p.121). A cocaína, por exemplo, foi introduzida como medicamento na comunidade médica e utilizada como anestésico e para outros fins terapêuticos. Enquanto, por um lado, a farmacologia desenvolvia substâncias para tratar de transtornos mentais, por outro, o uso substâncias com fins não-médicos é tido como abuso.

Os dois aspectos mantêm uma relação estreita, já que o próprio uso das drogas pela medicina facilita enormemente o abuso das mesmas, e é também uma maneira de difusão; o saber médico acaba abrindo caminho - certamente não é esta a sua intenção original - para um tipo de instrumentação da medicação ou "saída" à qual as pessoas podem recorrer em determinadas situações (Gurfinkel, 2014, pp. 122-123).

No século XIX a psiquiatria isolou a toxicomania enquanto entidade clínica e viu em algumas drogas, como o LSD, uma possibilidade de explorar a loucura, já que elas possuíam em comum a excitação maníaca. A Toxicomania, como o próprio nome já expõe, entra na discussão médica da época entre a loucura e a mania. O impulso era a característica principal dessa categoria, que também carregava, entre seus sintomas, o delírio, a obsessão e a alucinação. Para além do ato de usar substâncias tóxicas, a categoria clínica toxicomania surge na psiquiatria como uma necessidade de se intoxicar. Trata-se mais das tendências impulsivas (ou excitações maníacas) direcionadas às substâncias (Santiago, 2017).

Paralelamente ao nascimento da toxicomania enquanto objeto da psiquiatria, nascia a psicanálise. No que concerne a essa área de conhecimento, a demanda pela compreensão desse fenômeno enfrentou (e ainda enfrenta) vários obstáculos nesse percurso, que vão desde a compreensão do significado do uso aos impasses na clínica. A própria dificuldade em distinguir o que é hábito do 
que é dependência também se mostra um impasse para as definições teóricas. Como poderemos ver neste capítulo, não há um consenso.

Segundo Gurfinkel (2014), a adicção é "o uso compulsivo de um determinado objeto e, enquanto tal, se trata de uma ação de caráter impulsivo e irrefreável. A pessoa se sente impelida ao uso do objeto, e se vê incapaz de deixar de fazê-lo" (p. 49). O autor ainda compara a adicção a uma forma de escravização, na qual o sujeito não possui mais liberdade para escolher usar ou não o objeto. O termo "adicto", a propósito, vem do latim Addictus, que significa "aquele que foi entregue a outrem". Historicamente esse termo era atribuído aos escravos por dívidas em Roma. A prisão imposta aos devedores evoca bem o status do dependente assujeitado aos imperativos processos primários. O sujeito que, a princípio, optou por relacionar-se com um objeto vira ele mesmo objeto de seu objeto (Pages-Berthier, 1993).

Ao longo da história, o significado do uso de drogas mudou, as modalidades de uso mudaram e as classificações clínicas também. Essas mudanças foram acompanhadas pela psicanálise, que desde a modernidade vem se empenhando em estudar e desenvolver formas de melhor compreender esse complexo fenômeno. A complexidade está no fato de que a psicanálise não se debruça sobre os efeitos neuroquímicos das substâncias, enfocando mais no lugar que elas têm nos circuitos afetivos dos sujeitos e da sociedade.

Neste capítulo, acompanharemos de que forma a psicanálise se ocupou dessa temática, começando por Freud e suas pontuais contribuições teóricas e depois partindo para os pós-freudianos que buscaram compreender as toxicomanias a partir de diferentes perspectivas. Esse resgate às teorias iniciais é essencial para que possamos compreender o percurso teórico e suas modificações a partir da influência de novos autores e novos conceitos. Ademais, as mudanças de perspectiva teórica acompanham as próprias transformações sociais contemporâneas a elas, nos mostrando o caminho trilhado até aqui e dando pistas para os próximos passos.

\section{1}

\section{Freud}

Freud não se debruçou sobre o tema das toxicomanias especificamente, mas é possível encontrar em sua obra algumas menções ao tema, bem como o relato de sua experiência com a cocaína enquanto substância prescrita e também utilizada por ele. Freud sofreu de depressão por longos anos e a cocaína era frequentemente utilizada por ele como antidepressivo. Além da euforia mental, o aumento da libido e do vigor físico fora descrito positivamente por ele. Gurfinkel (2014) supõe que o motivo pelo qual Freud não se aprofundou no 
tratamento e investigação das toxicomanias era profundamente pessoal. Freud fora viciado em charuto por mais de cinquenta anos, o que lhe causou câncer de boca. Mesmo após a descoberta da doença e contrariando todas as recomendações médicas, Freud permaneceu fumando até que seu organismo não suportasse mais a fumaça. Outra especulação feita por Gurfinkel acerca da falta de trabalhos de Freud na temática das toxicomanias é que a marca das críticas que o autor recebera por seus trabalhos sobre a cocaína o fizeram recuar em qualquer desenvolvimento sobre o assunto. Ainda assim, é possível encontrar algumas formulações espalhadas por suas obras. A teoria do funcionamento do aparelho psíquico, sua metapsicologia e psicopatologia forneceram elementos para que autores posteriormente investigassem com mais afinco o tema das toxicomanias.

Em 1884, Freud escreveu um trabalho denominado "Sobre a coca", no qual comenta sobre os efeitos estimulantes e o potencial terapêutico da droga. Ao longo de seu comentário, Freud indica fortemente a cocaína para fins terapêuticos, exaltando seu potencial analgésico, anestésico e também como aliado no tratamento dos distúrbios digestivos. Em 1885, em "Contribuição para nossos conhecimentos sobre os efeitos da coca", ele comenta sobre o aumento da força muscular sob efeito da cocaína (Freud, 1897a/1996).

Além das recomendações feitas em seu trabalho de 1884 sobre o uso da cocaína no tratamento de perturbações digestivas, caquexia, asma, histeria, neurastenia e também como aliada no tratamento da adicção ao álcool e morfina, Freud ainda apostou na ação estimulante da substância para o tratamento da melancolia. Em uma conferência em 1885, ressaltou que já existiam drogas com a função de reduzir a excitação nervosa, mas não havia método destinado a estimular a atividade psíquica, apontando a cocaína como droga promissora nesse sentido. Esta pode ser considerada uma contribuição de Freud à psiquiatria, pois apontava a necessidade de investigação de substâncias estimulantes para tratar da melancolia e estados de depressão do sistema nervoso sem lesão orgânica. Ironicamente, a cocaína também fora utilizada (e divulgada) para fins de tratar o vício em morfina e álcool, elementos da toxicomania fortemente explorados pela psiquiatria moderna (Gurfinkel, 2014).

Em 1887, em seu "Comentários sobre a dependência da cocaína e o medo da cocaína", Freud - que indicara a cocaína para alívio da abstinência da morfina - alega que a dependência à cocaína só se manifestava nos dependentes de outras drogas, afirmando então que a cocaína não poderia ser responsabilizada por isso. Esses comentários foram uma resposta às críticas que vinha recebendo sobre o emprego médico da droga (Freud, 1897a/1996). Nesse artigo, Freud aponta que as reações à droga variam de acordo com o 
usuário e que isso ocorria devido a uma predisposição pessoal. Há, aqui, uma tentativa pioneira de deslocar a abordagem da droga para o usuário. Quando fala sobre a dependência e o medo da cocaína, ele foca não mais em seus efeitos, mas na relação estabelecida com a droga (Gurfinkel, 2014).

$\mathrm{Na}$ carta $\mathrm{n}^{\mathrm{o}} 79$ escrita à Fliess, Freud (1897b/1996) afirma que a masturbação é o vício primário e que os vícios posteriores (como álcool, tabaco, morfina) são substitutos da masturbação. Freud afirma que o papel desse vício na histeria é imenso e também um grande obstáculo, questionando se esse vício seria curável ou se a análise, diante dele, se contentaria em transformar o caso de histeria num caso de neurastenia.

No ano seguinte, Freud (1898/1996) escreve "A sexualidade na etiologia das neuroses", onde disserta mais sobre o vício em masturbação e ressalta que o tratamento para esse vício, assim como para qualquer outro, deve ser realizado em uma instituição e com supervisão médica. Ele aponta que, diante de uma tristeza, o dependente recorre a uma forma cômoda de satisfação e que o tratamento médico consiste em reconduzi-lo a um contato sexual normal, ressaltando que a necessidade de satisfação não poderia mais ser silenciada, mas deslocada para outro caminho. Nessa ocasião, o autor comenta que o tratamento para romper um vício não terá sucesso se o médico se contentar apenas em privar o dependente do narcótico, sem investigar a fonte desta necessidade que surge de forma imperativa. Comenta, ainda, que nem todos que usam morfina, cocaína etc. adquirem um vício, mas que essas substâncias servem como substitutos da falta de satisfação sexual.

Ao analisar um sonho de 1895 (o "sonho de Irma"), Freud escreve que na época do sonho vinha fazendo uso de cocaína para tratar de incômodos nasais e soube que uma paciente sua desenvolvera uma necrose na mucosa nasal devido ao uso da droga (por indicação sua). Comenta também que o uso da droga levou um amigo ao óbito - pois utilizara a cocaína por via injetável (Freud, 1900/1996).

Ao discorrer sobre os chistes, Freud (1905/2017) comenta que

A mudança do ânimo é a coisa mais valiosa que o álcool oferece ao ser humano, e é por isso que nem todos conseguem dispensar esse "veneno". O ânimo eufórico, seja endógeno ou toxicamente produzido, diminui as forças inibidoras - a crítica entre elas - e torna novamente acessíveis fontes de prazer sobre as quais pesava a repressão (p. 181).

Sendo assim, o adulto sob a influência do álcool se torna criança novamente, situação na qual há possibilidade de pensar livremente sem as limitações impostas pela lógica. Essa experiência, na qual a crítica se encontra enfraquecida, gera prazer (Freud, 1905/2017). 
Em "Sobre a mais comum depreciação na vida amorosa (contribuições à psicologia do amor II)", Freud (1912/2017) argumenta que a restrição cultural da vida amorosa leva à depreciação geral dos objetos sexuais e desenvolve seu texto focando nas pulsões em si. Ele comenta que os instintos sexuais são difíceis de "domar" e que a educação imposta através da cultura gera insatisfação, ou seja, ele apresenta aqui a ideia de que as exigências da cultura são incompatíveis com as exigências dos instintos sexuais. Uma vez cedendo às exigências da cultura e renunciando às exigências pulsionais estamos fadados à insatisfação e ao sofrimento.

A relação do amante de vinho com a bebida é comparada por Freud (1912/2017) a um modelo de "casamento feliz" onde há uma perfeita harmonia, diferente, segundo ele, da relação de um amante com seu objeto sexual. Nesse texto, Freud começa a cogitar que talvez o instinto sexual não seja passível de total satisfação, o que de certa forma põe em cheque sua formulação vigente - até então - sobre o princípio do prazer, regente principal do funcionamento psíquico.

A justificativa elaborada para explicar essa diferença na relação do amante com seu objeto é que, devido a barreira do incesto, o objeto do instinto sexual escolhido pelo amante seria sempre um substituto e nunca o objeto original. Aliás, todos os objetos seriam substitutos do original e nenhum desses substitutos traria satisfação plena, o que sustenta, portanto, a fome de estímulos tão presente na vida amorosa dos adultos, marcada por uma inconstância na escolha dos objetos (Freud, 1912/2017).

Ele encerra supondo que talvez não seja possível uma conciliação entre as exigências da cultura e dos instintos sexuais e, que, portanto o sofrimento não pode ser evitado. Ressalta, porém, que

\footnotetext{
Este sombrio prognóstico baseia-se, é verdade, apenas na conjectura de que a insatisfação cultural é a consequência necessária de certas peculiaridades que o instinto sexual adquiriu sob a pressão da cultura. Mas a própria incapacidade de o instinto sexual produzir plena satisfação, tão logo se submete às primeiras exigências da cultura, torna-se fonte das mais grandiosas realizações culturais, obtidas através da sublimação cada vez maior de seus componentes instintuais (Freud, 1912/2017, p. 282).
}

Essa ideia adianta o que mais tarde seria explanado no célebre texto "O mal-estar na civilização" (1930/2017) que, a partir das formulações do segundo dualismo pulsional, explora a insatisfação proveniente da renúncia pulsional frente às exigências da sociedade e as suas consequências, como as obras artísticas e científicas que derivam da sublimação.

Apesar da tentativa, não há um esclarecimento do autor do motivo pelo qual o vinho - este objeto parcial elegido pelo amante - seria suficiente para 
satisfazer o homem e mantê-lo fiel, enquanto que em suas relações amorosas um objeto sexual não seria. Ainda que ambos sejam objetos de natureza distinta, trata-se aqui de uma tentativa de substituição do objeto originário, ou seja, ambos são objetos parciais.

Por fim, é na obra "O mal-estar na civilização" que Freud (1930/2017) explora um pouco mais a temática do recurso às substâncias tóxicas como um dos paliativos indispensáveis diante do sofrimento da vida. Ele apresenta três recursos para essa finalidade. São eles: poderosas diversões, gratificações substitutivas e substâncias inebriantes, que nos tornam insensíveis à nossa miséria.

Dentre os métodos para evitar o desprazer, os que atuam no organismo são os mais interessantes, e a forma mais eficiente para intervir no organismo seria através da intoxicação, segundo Freud. Os químicos, além de produzirem sensação de prazer, também são capazes de nos tornar insensíveis ao desprazer.

O serviço dos narcóticos na luta pela felicidade e no afastamento da miséria é tão valorizado como benefício, que tanto indivíduos como povos lhes reservaram um sólido lugar em sua economia libidinal. A eles se deve não só o ganho imediato de prazer, mas também uma parcela muito desejada de independência em relação ao mundo externo. Sabe-se que com ajuda do "afasta-tristeza" podemos nos subtrair à pressão da realidade a qualquer momento e encontrar refúgio num mundo próprio que tenha melhores condições de sensibilidade. É notório que justamente essa característica dos entorpecentes determina também o seu perigo e nocividade. Em algumas circunstâncias eles são culpados pelo desperdício de grandes quantidades de energia que poderiam ser usadas na melhoria da sorte humana (Freud, 1930/2017, pp.33-34).

Em "O mal-estar na civilização" fica mais evidente que a satisfação total imposta pelo princípio do prazer não é possível, mas que os esforços para alcança-la não são deixados de lado. O princípio do prazer deixa de ser considerado uma máxima e torna-se uma tendência do aparelho psíquico, conforme já reformulado por Freud em 1920 no "Além do princípio do prazer". Mesmo com vários caminhos disponíveis, a satisfação plena não poderá ser alcançada. Freud (1930/2017) coloca que a felicidade "constitui um problema da economia libidinal do indivíduo" (p. 40). Afirma, ainda, que "o indivíduo que numa idade posterior fracassa nos esforços pela felicidade, encontra ainda consolo no prazer obtido por meio da intoxicação crônica, ou faz a desesperada tentativa de rebelião que é a psicose" (p. 42).

Como pudemos observar, apesar de não ter feito muitos estudos específicos sobre o tema das toxicomanias, Freud o incluiu no decorrer de sua obra. Ademais, sua teoria e seus conceitos serviram de base para que outros autores desenvolvessem estudos sobre a toxicomania. Os conceitos de pulsão, princípio do prazer, pulsão de morte, repetição, narcisismo, melancolia, fetichismo, 
perversão, as formulações sobre as neuroses atuais, a teoria da sexualidade e a organização pré-genital da libido são alguns exemplos de elaborações freudianas fundamentais para investigações e produções posteriores. Nos basearemos em vários desses conceitos para elaborarmos nosso trabalho e analisarmos a temática, levando sempre em consideração a singularidade do funcionamento psíquico dos sujeitos, a especificidade do instrumental teórico na vasta rede de abordagens dentro do referencial psicanalítico e a particularidade das relações estabelecidas com as diversas substâncias químicas.

\section{2}

\section{Pós-freudianos}

Veremos agora quais foram as principais formulações feitas pelos pósfreudianos acerca das toxicomanias e analisaremos os pontos de divergência e convergência entre autores e teorias. Buscaremos um denominador comum entre as teorias apresentadas e destacaremos as principais linhas de pensamento dentro da psicanálise.

$\mathrm{O}$ artigo pioneiro sobre as adicções a partir da teoria psicanalítica foi publicado por Abraham em 1908. O autor parte da teoria da sexualidade apresentada nos "Três ensaios sobre a sexualidade" publicado em 1905 por Freud. Em "As relações psicológicas entre a sexualidade e o alcoolismo", Abraham (1908/1988) ressalta que a satisfação sexual infantil é autoerótica e que parte das pulsões sexuais é recalcada. A sublimação, processo pelo qual as pulsões sexuais recalcadas são transformadas e deslocadas em direção às esferas sociais, é apontada por ele como processo indispensável para compreender os processos psíquicos normais e patológicos.

Abraham (1908) comenta que, embora seja sabido que o álcool atua suprimindo as resistências e aumentando a atividade sexual, a natureza desse feito não é investigada. Ao basear-se na teoria da sexualidade e na constituição psíquica psicanalítica, principalmente quando fala da criança perversa-polimorfa e dos mecanismos de recalque, Abraham retira o foco apenas da substância e passa a investigar a relação entre álcool e sexualidade apostando na existência de um fator individual no alcoolismo. Com o trabalho da sublimação comprometido, a conduta social passa a ter um caráter mais perverso, como observado no aumento da intimidade corporal entre amigos, nas brincadeiras obscenas, na paquera mais vulgar e no exibicionismo e voyeurismo. O autor comenta também que vários crimes brutais são cometidos em estado de intoxicação alcóolica, bem como incestos.

Abraham (1908) associa, ainda, o efeito do álcool a uma sensação de aumento da capacidade sexual e de aumento da masculinidade. Os efeitos da 
embriaguez são comparados à excitação sexual. No caso do alcoolismo crônico, a remoção das resistências é permanente, cristalizando-se em traços de caráter. O bebedor crônico mostra-se excessivamente sentimental e sem vergonha, e o álcool passa a não mais aumentar a capacidade sexual, mas a reduzi-la. O álcool é considerado por Abraham como um "falso amigo" (p. 590), pois parece dar um poder sexual e em seguida o retira.

Os alcóolatras, no entanto, não reconhecem os efeitos devastadores do uso crônico da bebida e se recusam a abrir mão dela. O autor compara essa situação às perversões sexuais, sendo o álcool uma fonte de estímulo sexual e prazer em si mesmo, substituindo o ato sexual. Assim como os voyeurs se contentavam sexualmente apenas em olhar, o alcóolatra se contentava com a excitação sexual provocada pela bebida, que passara a ser utilizada como substituta das atividades sexuais (Abraham, 1908).

Além da analogia entre alcoolismo e as perversões, existem relações íntimas entre as perversões e as neuroses, pois muitos sintomas neuróticos são expressão de fantasias sexuais perversas. Ademais, a resistência em relação aos sintomas é muito forte, sempre acompanhada de justificativas encobridoras que afastam qualquer possibilidade de aproximação da raiz do problema. Sobre isso, Abraham (1908) comenta: "Creio que devemos chegar à conclusão de que pela mesma razão que o neurótico protege seus sintomas o bebedor luta em defesa de seu alcoolismo. Isso representa sua atividade sexual" (p. 88, tradução nossa). ${ }^{1}$

Abraham (1908) também comenta que, no uso de narcóticos, a questão sexual também se faz presente. Pacientes histéricos frequentemente relatavam experiências insuportáveis que eram interpretadas como uma excitação sexual que se transformava em sintomas físicos e sensações de angústia. Alguns pacientes psicóticos interpretam a injeção de morfina como um ataque sexual, no qual a seringa e seu conteúdo tem um simbolismo sexual. Ele encerra seu trabalho defendendo que havia muitas questões não resolvidas na investigação do alcoolismo e que fatores externos, tais como influencias sociais e falhas na educação não eram suficientes para explicá-lo. Um fator individual parecia existir e por isso era necessário investigar as relações entre alcoolismo e a sexualidade.

Em 1910, em seu trabalho "Estados de sonho histéricos", Abraham escreve sobre um estado descrito por muitos pacientes como "de um sonho", no qual estão acordados, porém em um estado quase hipnótico, quase dormindo. Esses eventos sempre eram associados à ansiedade e quase sempre vinham

1"I think we must conclude that for the same reason that the neurotic protects his symptoms the drinker fights in defense of his alcoholism. It represents his sexual activity". 
acompanhados de outros sintomas.

Dentre os casos ilustrados, dois deles relatam pacientes histéricos viciados em masturbação. No primeiro caso, o paciente tinha fortes fobias, compulsões e ansiedade. O jovem relatou ao médico que suspeitava que esses "estados de sonho" eram uma espécie de manifestação de seus impulsos sexuais. O vício em masturbação foi adquirido na infância e perdurou por anos, e as tentativas e falhas na luta contra o vício deram origem à angústia, censura e hipocondria. Por muitos anos ele tentou não ter nenhuma atividade sexual, o que resultou na necessidade de substituição e gratificação através de diversas formas, dentre elas os estados de sonho.

Em outro paciente histérico grave - com frequentes crises de ansiedade e eventuais estados de sonho - as fantasias sexuais sempre o levavam à masturbação, que por sua vez sempre vinha acompanhada de um "estado de sonho". A ejaculação não chegava a ocorrer, pois o ato em si era suficiente, associado ao prazer do esvaziamento mental e fuga da realidade que o "estado de sonho" proporcionava (Abraham, 1910/1988).

A visão do autor nesse trabalho corrobora com seu texto anterior de 1908 no qual analisa o alcoolismo sob a luz da teoria da sexualidade freudiana e traz a noção freudiana (conforme exposta em 1897 na carta no 79 à Fliess) de que a masturbação é um vício primário e os demais vícios são substitutos a ela. Em 1908 ele comenta que um aspecto perverso do alcoolismo seria o fato do consumo da bebida bastar enquanto fonte de prazer em si mesma, substituindo o ato sexual. Em 1910, no segundo caso exposto, Abraham ressalta que a ejaculação não se fazia necessária, pois o prazer era adquirido por outra forma.

Em "O primeiro estágio pré-genital da libido" publicado em 1916, Abraham retoma a teoria freudiana sobre a organização pré-genital da libido e foca na oralidade pulsional, classicamente exemplificada pela satisfação da sucção na amamentação. É a ação da libido que produz prazer enquanto se apoia na necessidade de nutrição. No início da vida essas experiências são indissociáveis e só a posteriori a nutrição e a sucção por prazer serão separadas. Um caso patológico ilustrado nesse texto é o de um paciente viciado em tomar leite pois sentia satisfação sexual. Apenas quando não conseguia tomar o leite recorria à masturbação como recurso secundário à satisfação sexual.

A compulsão alimentar é um tópico apontado por Abraham (1916) para exemplificar esse tipo de comportamento pautado na oralidade pulsional. Ele comenta que geralmente ela vinha acompanhada de ansiedade extrema e, embora os pacientes conseguissem distinguir uma fome normal de uma fome "voraz", as confundiam com certa frequência. Ademais, uma fome voraz, 
mesmo que em excesso, ainda é um sintoma socialmente aceito. Ela pode representar a manifestação de impulsos libidinais.

Abraham (1916/1988) relata o caso de uma paciente que, acometida por uma fome incontrolável, possuía o hábito de acordar várias vezes durante a noite para se alimentar tal como um bebê faz. Pela manhã ela também acordava cedo e implorava pelo café da manhã na pensão na qual morava. O autor aponta que esse tipo de comportamento - de necessitar de comida em um curto período de tempo e sofrer caso seu desejo não seja atendido - era similar ao comportamento dos dependentes de morfina e álcool e que

Em relação a essas condições, a psicanálise conseguiu mostrar que o veneno intoxicante proporciona ao paciente uma gratificação substitutiva pela atividade de sua libido que lhe é negada. O sintoma de comer excessivamente e compulsivamente pode ser encarado da mesma maneira (p. 264, tradução nossa). ${ }^{2}$

Abraham ressalta que apesar da referida paciente não desfrutar de uma noite tranquila de sono por conta dos ataques de fome, a mesma era muito resistente à análise ou qualquer outro tratamento que a fizesse desistir das refeições noturnas. O prazer estava não apenas nas refeições, mas em todo o processo de busca e preparo dos alimentos.

Outro exemplo interessante foi o do paciente que possuía o hábito de chupar o dedo para dormir e após diversas censuras passou a sugar a ponta do travesseiro. Posteriormente ele transferiu esse hábito para o vício em se masturbar para pegar no sono e, após se dispor a parar a prática da masturbação e apresentar, por consequência, uma forte insônia, viciou-se em remédios para dormir. Fica bem explícito aqui os caminhos que a libido percorre a fim de conseguir a satisfação sexual imperativa para que o homem conseguisse relaxar e dormir (Abraham, 1916).

A dominância do prazer oral e as práticas estimulantes permanecem na vida adulta por formas mais extremas (como nos casos supracitados) ou através de pessoas que ainda precisavam prestar certo "tributo" à zona oral sem que desenvolvessem sintomas graves. Algumas pessoas conseguiram sublimar parte de sua libido, mas o autoerotismo ainda se mostrava imperativo quanto à forma mais eficaz de alcançar a concentração e empenho no trabalho, como exemplificado no hábito de roer as unhas, as pontas da caneta ou mesmo de fumar.

Abraham, contudo, faz um comentário importante em relação à distinção entre um hábito normal e uma compulsão patológica. Ele afirma que é muito

2 "Regarding those conditions, psycho-analysis has succeeded in showing that the intoxicating poison affords the patient a substitutive gratification for that activity of his libido which is denied him. The symptom of excessive and compulsive eating may be regarded in the same light." 
difícil fazer uma distinção nítida entre ambos, mas sugere que a tolerância à abstinência seja um indicativo, pois a reação à frustação de uma fonte de prazer na qual o sujeito está fixado gera uma marca patológica que o leva à formação de sintomas. Uma pessoa "normal", portanto, apesar de ser marcada por influência de suas necessidades sexuais, consegue tolerar a falta temporária de gratificação além de também dispor de gratificações substitutivas através da sublimação.

Abraham (1916) compara alguns neuróticos com crianças mimadas, pois são intolerantes à diminuição de prazeres e dependem de constante gratificação. Diante da falta dessa gratificação habitual, surge uma espécie de depressão. Sobre a função da gratificação ele comenta: "A gratificação auto-erótica da pessoa neurótica tem dois usos: previne a depressão dos espíritos quando está ameaçada e a remove quando está lá" (p.271, tradução nossa) ${ }^{3}$

O autor cita a questão do álcool como um corretivo para a depressão, mas não entra em mais detalhes pois "seu efeito como narcótico complica o assunto" (Abraham, 1916, p. 272). ${ }^{4}$ Ainda sim afirma que esses comportamentos tinham origem profundamente infantil.

Fica bem claro que Abraham possui uma abordagem pulsional e, especialmente aqui, aborda a pulsionalidade oral como fator preponderante para tratar de determinados comportamentos atípicos como compulsões alimentares, sucção dos dedos e até ingestão compulsiva de bebidas alcóolicas, ainda que esse assunto não tenha sido abordado com mais detalhes. É evidente para o autor que esses comportamentos tinham origem altamente infantil e eram perceptíveis nas reações, intolerância à frustração e necessidade de gratificação constante e imediata.

Abraham posteriormente vai se debruçar sobre o tema da oralidade pulsional em outros trabalhos, como em "A influência do erotismo oral na formação do caráter" e em "Um breve estudo do desenvolvimento da libido visto à luz de transtornos mentais", ambos escritos em 1924. Neste último trabalho Abraham comenta que "Na psiquiatria clínica, o estado maníaco sempre foi comparado a um estado de intoxicação no qual todas as inibições existentes são eliminadas" (1924/1988, p. 470, tradução nossa) ${ }^{5}$, o que corrobora com seus comentários previamente feitos sobre a suspensão dos mecanismos de defesa diante da intoxicação por álcool ou qualquer outra substância.

3"The neurotic person's auto-erotic gratification has two uses: it prevents a depression of spirits when it is threatened and removes it when it is there".

4 "its effect as a narcotic complicates the matter".

5 "In clinical psychiatry the manic state has always been likened to a state of intoxication in which all existing inhibitions are swept away". 
Sándor Ferenczi, também aluno de Freud, escreveu em 1911 o texto "O papel da homossexualidade na patogênese da paranoia", no qual cita alguns casos clínicos para exemplificar sua teoria de que a homossexualidade teria um papel primordial na patogenia da paranoia. Em um dos exemplos citado, o de um homem com alcoolismo crônico e ciúme paranoico, Ferenczi (1911a/1991) associa a paranoia e o recurso ao álcool como fruto de desejo homossexual recalcado, onde o "ciúme dirigido contra os homens era tão-só a projeção de sua própria atração erótica pelos homens" (p.159). Segundo ele,

O álcool, a que é lícito chamar o veneno da censura intelectual e moral, despojou de sua sublimação, em grande parte (mas não totalmente), sua homossexualidade sublimada em cordialidade, obsequiosidade e submissão, e ele atribuía muito simplesmente à mulher o erotismo homossexual assim posto a nu e que era incompatível com a consciência desse homem de uma alta moralidade, em muitos outros aspectos (Ferenczi, 1911a/1991, p. 159).

O papel que o álcool exercia aqui, segundo Ferenczi, era o destruir a sublimação e revelar o verdadeiro objeto sexual do indivíduo. Essa constatação - de que o álcool possui o poder de destruir a sublimação - já havia sido abordada por Abraham em 1908, como já comentamos previamente. Ao comentar a ação do álcool sobre as sublimações, Ferenczi (1911a/1991) faz uma importante colocação para a época, a de que o álcool não é a causa da doença, mas uma consequência dela. No caso do paciente em questão, este recorria à bebida devido aos seus desejos homossexuais que, após serem postos à superfície com a queda das resistências, acarretaram em ciúmes paranoicos e projeção - única forma cuja consciência conseguia lidar. Esse processo foi a forma encontrada pelo paciente de tranquilizar-se e de assegurar a si mesmo de que era sua mulher que se interessava excessivamente pelo sexo masculino e não ele.

Ferenczi (1911a/1991) faz uma importante crítica ao fato do movimento anti-alcoolismo ignorar o recurso excessivo ao álcool como uma consequência e não causa das neuroses. Para ilustrar seu ponto, cita o exemplo do exercito alemão que, após propagandas anti-álcool, obteve uma diminuição significativa do número de alcóolatras, mas em contrapartida se viu diante do aumento considerável de outras enfermidades neuróticas e psicóticas. Portanto, a vitória sobre o alcoolismo era apenas aparente, pois o psiquismo privado de álcool encontraria outras formas de refugiar-se na doença. Ferenczi (1911a/1991) advoga que é necessário saber a causa antes de qualquer coisa, pois "o alcoolismo do indivíduo, como da sociedade, só pode curar-se pela análise, que descobre e neutraliza as causas que levam a refugiar-se na droga " (p. 160). Diante das medidas da época para tratar dessa questão, Ferenczi lamenta os 
esforços desperdiçados na luta contra o alcoolismo que, apesar da boa vontade, dispunha de uma ótica errada sobre o problema.

No mesmo ano o autor escreve outro artigo a fim de responder as críticas recebidas ao seu artigo anterior no que diz respeito ao seu posicionamento em relação ao movimento antialcoólico. Em "O álcool e as neuroses", Ferenczi (1911b/1991) defende-se alegando que suas constatações foram construídas com base em anos de experiência e observação clínica. Cita que observou pacientes mergulharem na embriaguez e apresentarem sintomas desproporcionais mesmo após consumirem uma dose mínima de álcool, e conclui afirmando que

A responsabilidade dos sintomas de embriaguez não incumbia, em nenhum caso, somente ao álcool. A bebida agia como fator desencadeante, destruindo as sublimações, impedindo o recalcamento, mas a causa fundamental dos sintomas deveria ser procurada ao nível dos desejos profundos que reclamam satisfação. Enquanto para certos sujeitos "intolerantes ao álcool" a bebida é uma tentativa inconsciente de autocura pelo veneno, outros neuróticos, correndo o risco de mergulhar no alcoolismo crônico, empregam esse produto, conscientemente e com êxito, como medicamento (Abraham, 1911b/1991, p. $175)$.

Ferenczi não apenas continua defendendo que o álcool não deve ser considerado a causa das neuroses e sim, a consequência, mas também apresenta a ambivalência potencial do álcool, que pode vir a ser um medicamento ou um veneno, dependendo da relação estabelecida por cada sujeito com a bebida.

Outros pontos defendidos no texto são: o de que o recurso ao álcool parece ser mais frequente em indivíduos que necessitam de fontes de prazer externas - pois o álcool seria uma forma de compensar a euforia endógena que falta ao sujeito - e que o zelo antialcoólico seria um deslocamento da resistência. Ferenczi (1911b/1991) deduz que a privação de álcool poderia ser uma punição a um sentimento de culpa de origem sexual, ou seja, o antialcoólico, segundo ele, se autorizaria viver sua libido livremente, mas ao preço do sacrifício da renúncia ao álcool.

Apesar da lógica julgar os motivos pelos quais alguém recorre ao álcool como "estúpidos", Ferenczi (1911b/1991) defende que "a psicanálise permite uma melhor compreensão dessa fragilidade, dessa desproporção entre os motivos e os atos. (Vulnerabilidade de um complexo, deslocamento de afeto, fuga na doença, etc)" (p. 177).

O artigo "Os efeitos psíquicos das substâncias tóxicas e toxóides" publicado em 1935 por Alfred Gross não foi um dos trabalhos mais prestigiados na área, mas traz alguns levantamentos importantes. Nele, o autor busca examinar os efeitos das substâncias no psiquismo. Partindo do pressuposto de que a adicção seria apenas uma reação das substâncias, apesar de ser uma reação 
extrema, Gross tenta estudar o fenômeno levando em consideração exclusivamente as substâncias em questão, excluindo o sujeito e a relação que ele estabelece com o tóxico.

Gross (1935) buscou uma fórmula para entender os efeitos das drogas e logo percebeu que as dividir como "produtoras de prazer" e "livradoras de dor" era insuficiente, pois cada pessoa reagia de forma diferente à mesma substância. O princípio do prazer, portanto, não parecia predominar nessa situação. Na tentativa de achar denominadores comuns, o autor reduziu as diversas variáveis envolvidas no uso e nos efeitos das substâncias em cinco: tipo de droga usada; quantidade; personalidade do usuário; possibilidades de reação e forma de incorporação da droga.

Ele começou seus estudos a partir de dois tipos de drogas: as estimulantes e as sedativas, e logo viu que os dois tipos afetam o mesmo sistema, entretanto gerava efeitos diferentes. Um tipo estimula e o outro desacelera os processos psíquicos, o que chamou de efeito tóxico primário. Ao analisar o estudo de Gross, Loose (2002) relaciona os achados de Gross com a teoria pulsional de Freud ao comparar os elementos da teoria tais como fonte, pressão, objeto e finalidade com os elementos presentes nas substâncias e a forma como estes atuavam no funcionamento psíquico.

Gross (1935) introduziu em seu estudo, então, outras categorias de drogas tais como analgésicos, hipnóticos e narcóticos. Ao fazer isso, ele percebeu que as drogas atuavam no sistema perceptivo, ou seja, os efeitos causados pelos estímulos das drogas eram puramente "quantitativos" e sensoriais, algo que de certa forma coadunava com a teoria energética freudiana. Contudo, essa variação de energia poderia ser sentida como prazer, como dor ou como qualquer outro sentimento. Essa constatação levou às importantes conclusões: que o princípio do prazer não era predominante na ação dos tóxicos, que os efeitos poderiam ser imprevisíveis e estavam sujeitos a um processo primário que os afetavam e que o impulso ao uso de drogas não era decorrente de nenhum "processo tóxico primário", mas sim um processo psíquico independente, fruto de uma energia psíquica. A diferença entre Gross e Freud, segundo Loose (2002), é que enquanto Freud buscava encontrar no organismo uma energia psíquica afetada pela cocaína, Gross localizava essa energia exclusivamente na psique. Para ambos, no entanto, essa energia era imprevisível.

A partir desse trabalho, Gross (1935) acredita ter chegado a uma fórmula e define três características sobre o funcionamento dos tóxicos. A primeira característica proposta afirma que a ação da droga para no limite da psique, onde o processo primário entra em ação. Ele afirma que a droga é uma força "cega" e é deixada de fora da dinâmica psíquica interna. Uma vez que a força 
da droga é posta em movimento, ela adquire sua própria dinâmica. A segunda característica proposta afirma que esse processo primário é parte da economia psíquica. A energia psíquica não é proporcional à energia tóxica e a energia psíquica é objeto do processo primário e mobilizada pela força tóxica. O que importa é o deslocamento da energia e que a quantidade disponível de energia psíquica para o processo primário é variável. A conclusão tirada foi que a ação do tóxico está sujeita à economia psíquica existente e que a adicção não tinha relação com a ação tóxica da droga. O diferencial encontrado em seu trabalho foi que segundo Gross, as drogas não geram energia, mas liberam-na.

A terceira afirmação é que o processo primário modifica a energia mudando sua forma e deslocando sua quantidade. Para Gross (1935), o vício não é produzido pelas drogas, mas pela energia inerente à psique que, sendo limitada, demanda que a substância a substitua. Ele acredita que a variação dessa energia psíquica é governada por leis, mas não sabe quais leis são essas. $\mathrm{Na}$ tentativa de explicar a variabilidade das energias, Gross usa uma metáfora na qual compara o fluxo de água de uma cachoeira a uma energia psíquica que flui continuamente em uma determinada quantidade. Os mecanismos de defesa do aparelho psíquico do neurótico seriam como uma barragem nesse fluxo e a substância tóxica seria uma força que suspenderia essa barragem para que a energia psíquica escoasse completamente. Com o tempo, a ação da droga enfraquece e assim surge a demanda de uma abstinência temporária para que posteriormente a energia psíquica possa escoar com a maior intensidade quando a barreira for suspensa. Essa comparação tem o objetivo de apontar a droga como apenas um veículo para o fluxo e deslocamento da energia psíquica que seria ela mesma a fonte de ação tóxica.

Gross (1935) faz uma grande contribuição quando aponta que a toxicidade faz parte do indivíduo e não necessariamente da droga. O problema está na localização dessa energia no que Gross entende por psique. Os efeitos das drogas afetam mente e corpo, e a divisão entre ambos não é clara e absoluta. Loose (2002) comenta que o erro fundamental na formulação de Gross foi ter deixado de fora de sua investigação o sujeito. Não é possível saber como as drogas afetam alguém a menos que você pergunte.

Apesar de ter apontado que as substâncias afetavam de formas distintas os indivíduos e de ter atestado que o princípio do prazer não comanda as relações com as drogas, Gross se manteve numa perspectiva quantitativa e econômica em sua discussão, atendo-se a um fluxo de energia psíquica (ela mesma causadora das adicções) que seria regulado pela ação dos tóxicos.

Sándor Radó (1926 e 1933) foi o primeiro autor que atribuiu à toxicomania o estatuto de categoria clínica diferente das demais existentes até então 
na psicanálise. A partir do conceito de "orgasmo alimentar" da criança amamentada, Radó introduziu a noção de "orgasmo farmacogênico" e aproximou as duas experiências por apostar no caráter auto-erótico e no papel primordial da oralidade em ambas. Ele cunhou o termo Pharmacothymia para se referir às toxicomanias e sua investigação apontou para uma patologia no psiquismo, na qual o impulso que leva o sujeito ao uso da droga e altera seu humor e suas vontades (Pages-Berthier, 1993).

Radó faz uma importante contribuição quando define a Pharmacothymia como um processo cíclico próximo aos estados maníacos-depressivos. Nela, através de um artifício, o eu se mantém intacto, ou seja, diante de uma depressão inicial a droga será um escudo contra a dor e o sofrimento e restaurará a onipotência narcísica do sujeito. É, pois, um movimento autoerótico à medida em que o eu faz esse movimento de buscar a substância para esse propósito. Nesse sentido, Radó apresenta a Pharmacothymia como uma espécie de desordem narcísica que destrói a organização natural do eu e sua tolerância à dor. Essa "fortificação" do eu não permite que o sujeito perceba sua auto-destruição, pois está envolto por uma sensação de imortalidade e invulnerabilidade (Santiago, 2017).

Esse mecanismo farmacotímico, no entanto, falha. A depressão se instala e a dependência aumenta. Há uma tentativa de compensar a angústia com aumento do uso da substância e, consequentemente, a vida muda e segue para um processo de "desintegração moral" (p.148). O prazer farmacotímico substitui o prazer genital progressivamente até que haja um desligamento da atividade sexual. No início, o movimento auto-erótico tem como modelo a masturbação infantil e então o prazer passa a advir de uma organização sexual artificial. Os objetos de amor passam a ser desnecessários à medida em que o processo farmacogênico substitui o ato sexual genital ao criar uma "nova genitalidade". A intoxicação vira ela mesma um objetivo e um ato sexual (Santiago, 2017).

É evidente que Radó segue os passos dos alunos de Freud que já vinham investigando as toxicomanias a partir da teoria da sexualidade e associando o uso de substâncias com estágios pré-genitais da libido (sobretudo a oralidade) e também apontando aspectos perversos. Radó tenta relacionar os fenômenos clínicos com a regressão libidinal quando associa a oralidade e o orgasmo alimentar às toxicomanias e aponta para uma homossexualidade latente, associando masoquismo e homossexualidade. Essa questão, porém, não foi aprofundada. Ele foca na desgenitalização - que já vinha sendo trabalhada por outros autores - e contribui teoricamente com uma nova classificação das toxicomanias enquanto um fenômeno clínico que diz respeito a um distúrbio 
narcísico. Radó também parece ser o primeiro autor a enfatizar a natureza "deteriorante" do vício em drogas.

Em 1958, já nos Estados Unidos e adepto de uma teoria cada vez mais próxima da medicina e psiquiatria de inspiração biológica (Roudinesco \& Plon, 1998), Radó divide a toxicomania em três grupos: o grupo psiconeurótico ou maníaco-depressivo, o esquizofrênico e o psicopata. Em relação ao tratamento, ele defende que a abstinência deva ser feita preferencialmente em um hospital (para evitar perigos de violência e suicídio) e aponta que de modo geral o prognóstico da toxicomania é desfavorável (Rosenfeld, 1964/1965).

Ernst Simmel inaugurou uma clínica em Berlim na qual tratava, dentre outros pacientes, toxicômanos e alcoolistas. A partir de suas experiências clínicas e, partindo de formulações psicanalíticas existentes até então, avança em alguns pontos teóricos. Além de ressaltar a regressão da libido e as fases pré-genitais como fatores importantes na etiologia da toxicomania, Simmel (1927, 1947) também segue Radó em sua perspectiva da toxicomania como uma manifestação próxima à neurose maníaco-depressiva e quando aponta para um distúrbio narcísico.

O avanço feito, nesse aspecto, foi a consideração de que na toxicomania operam mecanismos obsessivos, portanto, trata-se de uma neurose narcísica e não uma verdadeira psicose. Esses mecanismos obsessivos se manifestam num superego severo e exigente que afeta o alcoolista. Para Simmel, esses mecanismos obsessivos são uma forma de lutar contra a doença maníacodepressiva. Ele compara o alcoolismo com a masturbação e ao ritual obsessivo, no sentido de que o desejo de se intoxicar seja uma reprodução de um conflito ligado à masturbação (Santiago, 2017).

Simmel corrobora com Radó na ideia da toxicomania ser um mecanismo de defesa contra a melancolia, gerando uma mania artificial que é progressiva. Nesse processo, o recurso à droga, que a princípio protegia o eu do sofrimento e da realidade, dá lugar a um processo crônico no qual todos os objetos são substituídos pelo álcool. Toda a agressividade que anteriormente era dirigida aos objetos, volta-se para o eu. Em virtude da ação destrutiva do supereu, o eu começa a sofrer os efeitos de sua desintegração.

O que ocorre, portanto, é que após a prática de intoxicação crônica ter sido instalada, o sujeito torna-se progressivamente um melancólico. Quando sóbrios, os alcoolistas são acometidos por sentimentos de culpa e infelicidade próprios dessa condição. Simmel supõe que essa conjuntura melancólica que precede a mania alcóolica está ligada aos mecanismos do supereu, pois há uma necessidade de punição e as pulsões destrutivas voltam-se para o eu. Tais sentimentos, paradoxalmente, cessam sob o efeito do álcool, que não deixa de 
atuar de forma destrutiva no alcoolismo crônico (Santiago, 2017).

Simmel posteriormente propõe definir o grau de morbidez alcóolica baseado no nível de desintegração do eu. O álcool pode ajudar o sujeito a adaptar-se à realidade ou até mesmo condená-lo à desintegração progressiva, na qual regride às fases pré-genitais da organização libidinal. Em relação ao trabalho clínico, Simmel sugere que seja feito através de uma "correção" das forças que o levam a recusar o amor genital e "reconstituição" das exigências do supereu, ou seja, "o processo de alívio da dor melancólica resulta de sua ação sobre o funcionamento do supereu característico dos deprimidos" (Santiago, 2017, p.152).

Simmel corrobora com as perspectivas pós-freudianas de que a mania alcóolica é experimentada como uma sexualidade desgenitalizada que transforma experiências dolorosas em sensações agradáveis. Suas contribuições nessa perspectiva da melancolia e mania são a existência de instintos destrutivos voltados para o eu e o papel severo do supereu. A intoxicação agiria no sentido de adormecê-lo, ou seja, suprimir momentaneamente as inibições e apaziguar o sentimento de culpa.

Santiago (2017) aponta que Simmel reduz, aqui, as funções do supereu à censura e limitação, negligenciando as formulações freudianas do supereu como também um princípio de excesso que serve às exigências da pulsão de morte. A afirmação de Simmel de 1927 de que "o supereu alcoólico é solúvel no álcool" (p.150) leva em consideração esse aspecto limitador e severo do supereu, mas ignora a possibilidade de o recurso à intoxicação ser fruto também de uma ordem do supereu. Nesse sentido, o bebedor crônico está submetido a uma ordem de beber. Essa ordem é um imperativo de gozo.

Segundo a teoria freudiana, o supereu é herdeiro do complexo de édipo, ou seja, das marcas que um pai faz no sentido de submeter o sujeito às leis. O recurso à embriaguez visa reduzir as consequências da submissão à lei do pai ou negá-la? O imperativo de gozo é uma forma de contestar a tirania dessa figura? Essa discussão será retomada posteriormente.

Aluno de Abraham, Edward Glover (1928, 1932) também foi um dos principais psicanalistas pós-freudianos a abordarem a questão das toxicomanias. Inicialmente, ele seguiu as concepções de outros autores que defendiam o papel da regressão libidinal nas toxicomanias. A fixação pré-genital (sobretudo no estágio oral) aparece em sua obra como produto de frustrações vividas naquele momento e que futuramente ditariam as relações objetais do indivíduo (Santiago, 2017).

Glover, no entanto, dá um passo adiante nas formulações feitas até então quando considera que o processo de desgenitalização e substituição da 
sexualidade pelo álcool - já mencionado por outros autores - seria uma espécie de formação perversa. "O álcool deve quase toda sua atração ao fato de que é, antes de tudo, bem apropriado para vencer a angústia de castração, embora, a longo prazo, destrua seu próprio objetivo, acarretando ao sujeito a impotência e a morte" (Santiago, 2017, p.157).

Diferente do que propôs Abraham - que o álcool poderia aflorar tendências perversas -, Glover defende que o uso do álcool funciona como um substituto da sexualidade no sentido de ser um método de efetuar um curtocircuito nela, ou seja, esse método relaxa a pressão do recalque e invalida a sublimação ao mesmo tempo (Santiago, 2017).

Em seus trabalhos posteriores, Glover abandona e critica a primazia da concepção de regressão libidinal para explicar o fenômeno da toxicomania. A regressão à oralidade e à homossexualidade não podia mais sustentar a etiologia dos casos, então, inspirado por Melanie Klein, o autor parte para uma investigação pautada nas relações de objetos pré-edipianas. Ele busca definir uma etiologia própria da toxicomania e propõe que esta seria uma reação que representa a transição entre o desenvolvimento psíquico primitivo e a neurose. Glover flerta com a noção de perversão junto à toxicomania chegando a construir sua teoria com base na perversão, mas posteriormente define a toxicomania como variante dos estados limítrofes (Santiago, 2017).

Os estados transicionais, como ele denominou, estariam entre a neurose e a psicose. Essa nova denominação de Glover surge na tentativa de classificar e ordenar as estruturas clínicas freudianas de acordo com os mecanismos primários de introjeção e projeção. Os estados transicionais, no entanto, neutralizam a noção enrijecida de estrutura e essa nova organização não segue a lógica cronológica de estágio, mas sim a noção kleiniana de posição - que articula os elementos constitutivos, como as relações objetais, a estrutura do eu e as defesas contra angústia. Esses elementos se combinam e afetam as fantasias do sujeito (Santiago, 2017).

A ideia da existência de uma fantasia específica e de um fator sádico na escolha de uma substância nociva é também fruto da influência de Melanie Klein e traz à droga o estatuto de objeto parcial com propriedades sádicas. Nos mecanismos de introjeção e projeção em exercício na toxicomania, os objetos bons e ruins internos e externos seriam atacados pela droga. O uso de uma droga considerada nociva estaria relacionado a existência de um objeto interno ruim (Rosenfeld, 1964/1965).

Santiago (2017) aponta: "Essa assimilação sem retorno da droga ao objeto parcial adquire ainda mais consistência com a hipótese kleiniana do édipo precoce, concebida como uma fase pré-genital, portadora de uma forte carga 
de sadismo" (p.160). Nessa perspectiva, a toxicomania seria a fixação a um sistema edipiano transicional que estaria entre os núcleos edipianos primitivos (que produzem as angústias paranoides ou melancólicas) e o núcleo edipiano portador de reações obsessivas.

Como Simmel já havia sinalizado, elementos paranoicos e obsessivos estão presentes na toxicomania. Glover concorda com essa formulação, mas aponta que os mecanismos de projeção nos estados transicionais (como define a toxicomania) são mais resistentes que os obsessivos e menos evidentes que os paranoicos. Os mecanismos de projeção são lançados para o objeto droga, "pelo qual o ato toxicomaníaco exerce a função reparadora da reação psicótica, acarretada pelo processo de regressão" (Santiago, 207, p.161).

Para ele, as raízes da toxicomania estão na paranoia, mas há fortes laços com a neurose e especialmente com o fetichismo. Em suma, Glover considera a toxicomania uma forma de conter as reações sádicas paranoides e preservar o sentido de realidade. Há, na teoria de Glover, uma redução da toxicomania a uma formação fetichista, onde, tanto na toxicomania como na perversão, há a manutenção do sentido de realidade, exceto naquilo que tem relação com a droga para o toxicômano e com o fetiche para o perverso. Nesse sentido, o fetichismo está a serviço da proteção psíquica, salvaguardando um eu íntegro na realidade. A toxicomania encontra-se intermediária entre questões primitivas das psicoses e uma organização posterior neurótica (Santiago, 2017).

Santiago (2017) critica essa visão quando aponta que o fetichismo, como proposto por Freud, não está a serviço da proteção psíquica contra uma dissolução psicótica, mas sim contra a angústia de castração. O que o fetiche e a droga partilham em comum é o fato de serem recursos diante da angústia. Voltaremos a abordar essa questão do fetichismo posteriormente.

Apesar de continuar numa perspectiva pulsional e basear-se, a princípio, na ideia de regressão libidinal às organizações pré-genitais, Glover avança na discussão quando se baseia em elementos da teoria kleiniana para apontar relações de objeto, mecanismos de defesa tais como projeção e introjeção, apontar ansiedades paranoicas precoces pré-edipianas e estabelecer um novo lugar na teoria psicanalítica para a toxicomania. Ao apontar formações perversas como o fetichismo (que aparece como uma defesa à psicotização), psicose iminente e ainda elementos obsessivos, Glover termina por considerar a toxicomania um estado transicional entre a neurose e a psicose.

Wulff (1932) aproximou o tema da toxicomania com os transtornos alimentares quando apontou a existência de uma entidade compulsiva. Para ele, a necessidade de incorporação parcial do objeto representa uma introjeção erótica que substitui o relacionamento genital (Rosenfeld, 1964/1965). A satisfa- 
ção causada pelas drogas pode levar os neuróticos a tornarem-se toxicômanos, mas Wulff aponta, sobretudo, que a adicção pode ser um substituto perfeito aos ataques histéricos em alguns casos de histeria, pois os ataques estão situados, "por si mesmos, no limite entre o somático e o psíquico, pois são ao mesmo tempo a derivação catártica e direta, em ato, do sexual, e a representação simbólica, de forma encenada, de certos enredos ligados à história psicossexual pregressa" (Gurfinkel, 2014, p.165).

Knight (1937) considera o alcoolismo um sintoma e não uma doença. Ele aponta que durante o consumo excessivo de álcool, o indivíduo temporariamente entra num estado psicótico e há um movimento regressivo das pulsões libidinais e sádicas. Ele também considera que o alcoolismo é um recurso aos conflitos emocionais. O autor fez uma tentativa de definir o caráter do alcóolatra e sua constituição familiar a partir dos pacientes que atendeu. Nessa tentativa, ele inferiu que a mãe desse indivíduo seria super-protetora e indulgente, satisfazendo sempre o bebê. Isso geraria um indivíduo intolerante à frustração e que buscaria constantemente ter seus desejos satisfeitos pela via oral. Em fase adulta, o álcool teria a função da "chupeta" calmante. Já o pai do indivíduo seria pouco afetuoso e severo, o que geraria sentimentos de raiva e ressentimento no filho. O desejo de beber é relacionado por Knight como o desejo infantil do seio e desejo de desafiar a sociedade e aos pais. Após ter bebido, o indivíduo se sente arrependido e traído pelo álcool, mas mesmo de ressaca permanece fiel à bebida (Rosenfeld, 1964/1965).

O autor fez várias contribuições para o tema, sobretudo em relação ao tratamento do alcoolismo. Knight afirma que a análise clássica não tem eficácia com alcoólatras, pois eles não suportam o distanciamento do analista. Nesse sentido, ele compara o alcoólatra ao esquizofrênico por serem muito sensíveis a qualquer indicativo de rejeição por parte do analista. Para ele, o analista deve ter uma posição mais ativa e não tão crítica. Ele sugere que as entrevistas iniciais sejam feitas de forma amigável e com o paciente sentado, para que progressivamente ele possa ir para o sofá. Pontua também que, por conta da necessidade de indulgência dos alcóolatras, algumas necessidades devem ser atendidas ao invés de interpretadas. Por ter tratado vários pacientes alcóolatras em sanatório, Knight considera que a supervisão institucional é primordial. Ele observa que no tratamento em hospital a transferência é fragmentada e concorda com Simmel em relação às dificuldades técnicas no tratamento de dependentes de álcool e drogas (Rosenfeld, 1964/1965).

Fenichel (1945) abordou o vício em drogas e o vício sem drogas também. Para ele, o adicto visa satisfazer um desejo sexual arcaico, um desejo de segurança e um desejo de manutenção da auto-estima através dos efeitos das 
substâncias. Ele aponta a existência de um objetivo narcísico passivo que visa apenas a auto-gratificação. A intolerância à frustração e a dor também são apontados como características presentes nos adictos. Fenichel também aponta o desaparecimento do superego sob o álcool, como Simmel já havia pontuado. O autor também compara o ciclo da bebida com estados maníaco-depressivos, como já apontado por Radó, Simmel e Glover (Rosenfeld, 1964/1965).

Em relação ao tratamento, Fenichel sugere que o melhor momento para iniciar a análise é durante ou logo após a retirada da substância, mas que a abstinência não deve ser esperada, pois o paciente usará a droga novamente, especialmente quando houver aumento na resistência. Por esse motivo, ele defende que o tratamento deve ser feito em uma instituição (Rosenfeld, 1964/1965).

No campo das relações de objeto, Winnicott (1951) faz uma rápida alusão à toxicomania quando a define como uma patologia dos objetos transicionais. Ele define a toxicomania como a regressão ao estágio primitivo, onde os fenômenos transicionais não são uma questão. A droga seria um objeto parcial patológico que, posto no local de um objeto humano real (que não foi simbolizado), confere ao usuário uma sensação ilusória de potência (PagesBerthier, 1993).

Rosenfeld (1960/1965) tem uma posição intermediária entre o modelo pulsional e o modelo relacional. Ele ressalta o papel da oralidade pulsional e também dos mecanismos de defesa primitivos. Assim como os autores anteriores, Rosenfeld relaciona a toxicomania com o ciclo maníaco-depressivo quando associa a mania à onipotência destrutiva no período de uso e a depressão à identificação com objeto doente ou morto. A droga pode ser colocada nesse lugar de objeto mau ou persecutório e há a incorporação desse objeto com o qual o sujeito se identifica. Esse processo, no entanto, substitui todos os objetos ao invés de ajudar o sujeito a reencontrar o caminho da relação objetal (Pages-Berthier, 1993).

Para Bergeret (1982), não existe uma estrutura ou personalidade toxicômana. $\mathrm{O}$ vício pode se implantar em qualquer estrutura ou personalidade. Ele ressalta, no entanto, algumas características em comum das pessoas que se tornam dependentes: depressão, carências identificatórias e incapacidade de lidar com a violência natural, que se não for bem elaborada, gera a necessidade de prejudicar os outros e a si mesmo (Pages-Berthier, 1993).

Joyce McDougall (1982) se baseia nos distúrbios na relação eu-objeto e aposta na impossibilidade de identificação com uma mãe interna protetora. A falta de representação interna de uma instância materna tranquilizadora levará à necessidade de um objeto adictivo que desempe esse papel de objeto interno 
tranquilizador (Pages-Berthier, 1993).

Le Poulichet (1987) comenta esse paradoxo da droga como um dispositivo de autopreservação a partir da ambiguidade do "pharmakon" (ora remédio, ora veneno). Ela destaca que existe uma crença (decorrente da farmacologia) em uma substância onipotente, que trata a psique como um órgão. Ela descreve dois eixos pelos quais a toxicodependência é organizada: o eixo do suplemento, protegendo o sujeito da castração e o eixo da substituição, no qual a toxicomania compensa a falta de elaboração psíquica ao tentar reunir o corpo separado. Apesar da ambiguidade, a operação de pharmakon é um processo mais relacionado à automedicação do que à autodestruição (PagesBerthier, 1993).

Como pudemos observar, desde o princípio as investigações psicanalíticas não estavam pautadas principalmente nas substâncias, mas na escolha do sujeito ao usá-las, ou, como Ferenczi mesmo apontou, o alcoolismo é consequência e não causa das neuroses. As teorias iniciais tinham um caráter mais pulsional e estavam focadas na sexualidade genital, destacando o vício como uma substituição à masturbação e regressão às fases pré-genitais, sobretudo a oral (Abraham, Ferenczi, Radó, Simmel). Há na teoria produzida a primazia da ideia de desgenitalização, ou seja, substituição do ato sexual pelo ato toxicomaníaco (Abraham, Radó, Simmel, Wulff).

A compulsão alimentar é comparada à toxicomania por autores como Abraham e Wulff, e o destaque ao comportamento infantil, que precisa ser satisfeito imediatamente e não suporta a frustração, é citado por Abraham, Radó, Knight, Fenichel. A intoxicação é apontada por Abraham e Ferenczi como fator que suspende ou destrói as sublimações e um fator que enfraquece ou suspende a ação severa do superego por Simmel e Fenichel.

Ferenczi e Bergeret alegam que as pessoas melancólicas são mais propensas à toxicomania, pois buscam nas substâncias a euforia que lhes falta. A associação ao ciclo maníaco-depressivo é apontada por Radó, Simmel, Fenichel.

A questão narcísica é trazida por Radó quando aponta que as toxicomanias são distúrbios narcísicos. Simmel define as toxicomanias como neuroses narcísicas e Fenichel aponta um narcisismo passivo, com necessidade de autoerotismo e manutenção da auto-estima. Glover define a toxicomania como um estado transicional entre a neurose e a psicose. Já Knight defende que o vício não é uma doença, mas um sintoma. Bergeret segue a mesma linha, afirmando que não há uma estrutura ou personalidade específica do toxicômano.

O caráter auto-destrutivo do ato toxicomaníaco é comentado por Simmel, Bergeret, Radó e Glover. A questão do fetichismo aparece na obra de Glover quando define a toxicomania como uma formação perversa a serviço de um 
mecanismo de defesa contra uma psicose iminente. A perversão também é citada por Abraham quando comenta que as perversões aparecem sob efeito do tóxico e, consequentemente, na suspensão das sublimações.

Em relação ao tratamento, Knight aponta que a análise ortodoxa não deve ser utilizada e defende o tratamento institucional, assim como Fenichel. Radó, Knight, Simmel e Fenichel comentam sobres as dificuldades técnicas na clínica com toxicômanos e Radó comenta que o prognóstico não é favorável.

Há uma passagem do modelo pulsional para o relacional nas obras, como mostrado na obra de Simmel. Por influência de Melanie Klein, ele traz como novidade para a abordagem das toxicomanias os mecanismos de introjeção e projeção do objeto bom ou mau. Winnicott também aborda as drogas como objeto parcial e aponta a toxicomania como uma patologia dos objetos transicionais. McDougall segue a linha de que a toxicomania seria um distúrbio na relação eu-objeto e que a droga cumpriria a função tranquilizadora na falta de um objeto interno com essa função.

A partir dessas teorias apresentadas, analisaremos em seguida alguns dos conceitos utilizados por esses autores para discutirmos a toxicomania enquanto sintoma do sujeito e sintoma social. 


\section{4}

\section{Análise das Teorias à Luz dos Conceitos Psicanalíticos}

Após o levantamento das principais teorias elaboradas pelos autores pósfreudianos acerca das toxicomanias, foi possível observar o destaque de algumas ideias em relação a outras. Pontuamos alguns conceitos que apareceram, tais como: masturbação; período pré-genital; desgenitalização; pulsões; melancolia; psicose maníaco-depressiva; estado transicional; fetichismo; perversão; narcisismo; repetição; auto-destruição; supereu; objeto; impulsividade e sintoma.

Neste capítulo analisamos as teorias já apresentadas e também algumas proposições feitas por autores contemporâneos à luz dos principais conceitos psicanalíticos destacados. Os conceitos priorizados são: auto-erotismo, narcisismo, pulsões de morte; masoquismo; compulsão à repetição e objeto. Os conceitos de gozo e melancolia são brevemente comentados, bem como a perspectiva dos objetos a partir da teoria relacional. Ressaltamos que existem ainda mais perspectivas acerca das toxicomanias dentro da psicanálise, mas nos limitamos aos conceitos citados acima. Não discorremos sobre: a questão da perversão e do fetichismo; o acting out; as toxicomanias nas psicoses; as diversas formas de gozo nas toxicomanias e sua relação com o sintoma social.

\section{1}

\section{Do auto-erotismo ao narcisismo}

Como demonstramos no capítulo anterior, os conceitos de auto-erotismo e narcisismo foram usados por alguns autores pós-freudianos em suas formulações sobre as toxicomanias, como por exemplo quando Abraham, Ferenczi, Radó e Simmel compreenderam o vício em drogas como uma substituição à masturbação e apontaram que nas toxicomanias há um movimento de regressão libidinal às fases pré-genitais. Radó considerou a toxicomania um distúrbio narcísico, no qual o uso da droga (através de um movimento auto-erótico) teria a função de restaurar a onipotência narcísica. Simmel definiu a toxicomania como neurose narcísica, na qual o recurso às substâncias protege o eu do sofrimento e da realidade. Fenichel apontou para um "narcisismo passivo", visto que na visão do autor o objetivo do uso de tóxicos é a auto-gratificação e manutenção da auto-estima. Vamos analisar esses conceitos e de que forma eles dialogam com essas proposições e as elaboradas posteriormente por outros 
autores.

Em sua formulação da primeira tópica, Freud (1900-1901/1996) propõe um aparelho psíquico formado pelas instâncias pré-consciente, consciente e inconsciente, no qual a excitação sensorial resulta em uma descarga motora, seguindo o modelo de um aparelho reflexo. A energia a qual Freud se referia nesse momento (situada entre o físico e o psíquico) foi posteriormente denominada como pulsão e aprofundada em seu artigo de 1915 intitulado "As pulsões e seus destinos". Cabe aqui contextualizar um pouco sobre esse conceito. As pulsões foram consideradas por Freud "as verdadeiras forças motrizes por detrás dos progressos que conduziram o sistema nervoso, com sua capacidade ilimitada, a seu alto nível de desenvolvimento atual" (1915/2004, p.126).

$\mathrm{Na}$ conjuntura da primeira tópica, está posto que os representantes pulsionais visam sempre a satisfação e, na iminência de um desprazer, sofrem recalque. Freud (1915/2004) se ocupa em atribuir alguns termos às pulsões: força, fonte, meta e objeto. A força com que uma pulsão atua é constante. A pressão de uma pulsão pode ser definida como a força ou a medida da exigência de trabalho. Sendo a pressão inerente às pulsões, toda pulsão, portanto, é ativa, é dinâmica. A fonte de uma pulsão pode ser compreendida como um órgão ou parte do corpo que passou por um processo somático pelo qual a excitação vai ser transposta para a vida psíquica. A meta sempre é a satisfação, e o objeto é o meio através do qual a pulsão busca atingir a satisfação. O objeto pode ser deslocado inúmeras vezes no decorrer dos destinos das pulsões, e portanto, podemos compreender que a pulsão é sempre parcial.

No texto "Três ensaios sobre a teoria da sexualidade", Freud (1905/1996) disserta, dentre outros tópicos, sobre as etapas do desenvolvimento sexual infantil, condição da sexualidade humana. Ao apresentar o auto-erotismo, no qual atividades infantis corporais são fonte de satisfação, as pulsões são destacadas aqui como parciais ao passo que se satisfazem em diversas zonas erógenas. A passagem da sexualidade infantil - pautada na satisfação das pulsões parciais em diversas zonas - para a sexualidade adulta - genitalizada e direcionada a um objeto centralizador e totalizado - é apresentada aqui pela via do recalque decorrente do complexo de édipo. Em 1910 Freud adiciona uma nota ao texto e utiliza o termo narcisismo pela primeira vez ao referir-se aos homossexuais que, tomando a si mesmos como objetos sexuais, procuraram homens semelhantes a si (Roudinesco \& Plon, 1998).

Em seu artigo "Formulações sobre os dois princípios do acontecer psíquico", Freud (1911/2004) define dois grupos de pulsões de acordo com o funcionamento do aparelho psíquico: as pulsões sexuais - regidas pelo princípio do prazer - como aquelas que visam proporcionar prazer e evitar desprazer, e as 
pulsões de autoconservação - regidas pelo princípio de realidade -, que impõe restrições ao princípio do prazer no sentido de adaptação à realidade externa. Essa distinção configura o primeiro dualismo pulsional, e o conflito entre estas pulsões é apontado aqui como desencadeador das neuroses.

O narcisismo, proposto em 1910 como um tipo de escolha homossexual (no sentido do próprio ego ser uma escolha objetal) passa por uma modificação conceitual. O conceito passa a referir-se às diversas formas de organização da pulsão, à escolha objetal e também à constituição do eu.

Em 1914 Freud escreve "Sobre o Narcisismo", célebre obra que aprofunda o conceito de narcisismo e muda os rumos da teoria freudiana. Nessa obra, o conceito aparece como uma extensão da teoria da libido, pois é situado pelo autor entre o auto-erotismo e o amor objetal, ou seja, o narcisismo aparece nesse momento como presente em todas as pessoas e não apenas nos psicóticos ou homossexuais, como fora situado anteriormente.

O que está posto no narcisismo é que as pulsões sexuais passam a ser direcionadas para o eu inteiro e não apenas para zonas específicas. Freud (1914/2004) faz uma redistribuição das pulsões sexuais de forma que uma parte do seu investimento é direcionado ao eu (libido narcísica) e outra parte do investimento é direcionado aos objetos externos (libido objetal).

Queremos chamar atenção para o fato de que a princípio, as pulsões sexuais estão apoiadas nas pulsões de autopreservação (como no exemplo do objeto seio apoiado na função nutricional) e gradativamente se separam nas escolhas objetais. Pela perspectiva do princípio do prazer, o aumento da quantidade de investimento libidinal causaria desprazer, portanto, o direcionamento da libido para os objetos seria autopreservativa, ou seja, uma forma de proteção contra o adoecimento. Nessa perspectiva econômica, as libidos objetais e narcísicas alternam entre si, de modo que quando a libido objetal investe nos objetos externos, a libido narcísica diminui. Nas psicoses, a libido segue majoritariamente voltada para o eu.

Freud (1914/2004) divide o narcisismo em dois momentos, denominados primário e secundário. Os primeiros objetos sexuais são o próprio ser e as pessoas que se ocupam dele. O narcisismo primário manifesta-se, segundo Freud, na escolha objetal amorosa futura, no sentido de ter relação com o próprio ser ou com o primeiro objeto de amor. O narcisismo primário dos pais é transformado no amor objetal direcionado aos filhos, caracterizado pela supervalorização e atribuição de perfeição a estes.

Freud relaciona o narcisismo com a castração quando comenta que as pulsões sexuais são recalcadas por serem contrárias à moral e à cultura. O narcisismo infantil onipotente (no qual a criança é seu próprio ideal) dá lugar 
ao narcisismo secundário, no qual as identificações com as figuras parentais geram um ideal a ser seguido, um modelo de referência do eu.

Freud não faz uma distinção concreta entre o eu ideal e o ideal do eu, mas podemos presumir que o eu ideal é fruto do narcisismo primário e o ideal do eu é fruto do narcisismo secundário, no qual as escolhas objetais são marcadas pelo narcisismo primário. O ideal do eu é apontado aqui como uma instância do eu. Posteriormente, o ideal do eu ganha estatuto de uma instância independente do eu, por isso é considerado base para o supereu.

É importante frisar que a descoberta da libido narcísica e a sua distinção em relação à libido objetal modifica várias percepções concebidas até então, ao passo que a existência de uma libido narcísica modifica o estatuto da autopreservação de tipo de pulsão à função. Essa descoberta foi um ponto de partida para a elaboração de um novo dualismo pulsional, e a formulação do ideal do eu como um elemento constitutivo e regulador deu início a uma remodelação da teoria do aparelho psíquico, com a elaboração de uma segunda tópica.

É notória a relação entre o auto-erotismo e o narcisismo no que diz respeito à constituição do eu, porém, essa passagem do eu fragmentado que se satisfaz em si mesmo a partir das zonas erógenas (como exposto nos "três ensaios") para um eu unificado não é esclarecida por Freud. Partindo dessa lacuna, Jacques Lacan (1949/1998) escreve o artigo "O estádio do espelho como formador da função do eu" com o objetivo de explicar como se dá essa passagem e como o eu se constitui.

Lacan (1949/1998) nos mostra, a partir de uma releitura da segunda tópica freudiana, como o estádio do espelho atua na constituição do eu [moi]. O bebê, em sua insuficiência biológica e impotência motora, se antecipa numa identificação com sua imagem especular. Ele assume a imagem do espelho e do que é de fora (pessoas e objetos) como sendo sua imagem. É importante ressaltar que, antes desse bebê se identificar com o outro e se constituir como sujeito de linguagem, este já é inserido no mundo de linguagem por outrem (que representa a matriz simbólica). Nessa antecipação e identificação com imagem especular há a formação desse eu imaginário, que está situado antes mesmo de sua determinação social. Esse eu imaginário (ideal) vai dar origem às identificações secundárias e prefigurar as fantasias.

A conclusão do estádio do espelho se dá com a passagem do eu especular para o eu social, que inaugura a identificação com o semelhante e liga o eu a situações socialmente elaboradas, que demandam retenção de instintos pulsionais e escolhas objetais. Cabe ressaltar que o eu imaginário não é substituído pelo eu social uma vez que as identificações secundárias são feitas. 
Como já comentado por Freud (1914/2004), o narcisismo primário não se esvai complemente. Há um afastamento deste e depois uma tentativa de recuperá-lo.

Vanier (2005) comenta que o narcisismo primário instaura o eu imaginário [moi] a partir da soma das identificações. Este está relacionado à instância imaginária, e o eu $[j e]$, sujeito de linguagem e social, está ligado à instância simbólica. O "eu ideal" e "ideal do eu", já abordados por Freud em sua teorização sobre o narcisismo ganham, com Lacan, estatuto de imaginário e simbólico respectivamente.

Além da elaboração de um novo dualismo pulsional e de uma nova tópica do aparelho psíquico, o conceito de narcisismo trouxe elucidações acerca da constituição do eu, que se dá, como vimos, a partir das identificações e dos investimentos pulsionais em objetos externos. Veremos de que forma o conceito de narcisismo contribuiu para as teorias dos pós-freudianos e autores contemporâneos acerca das toxicomanias.

\subsection{1}

\section{Da Constituição do Eu às Toxicomanias}

A noção de auto-erotismo é utilizada por alguns pós-freudianos como Abraham (1908, 1910, 1916, 1924), Ferenczi (1911), Radó (1926,1933) e Simmel $(1927,1947)$ quando comparam a toxicomania com masturbação e supõem a existência de um movimento regressivo da libido às fases pré-genitais, em especial à fase oral. De acordo com o conceito de auto-erotismo e como as pulsões sexuais são satisfeitas a partir de zonas erógenas (e posteriormente em um Eu inteiro), essas percepções são pertinentes metapsicologicamente, ainda que não sejam suficientes para explicar todos os fatores envolvidos nas toxicomanias.

Quando alguns pós-freudianos como Radó (ibidem), Simmel (ibidem) e Fenichel (1945) apontam o elemento narcísico nas toxicomanias, fica clara a associação do narcisismo a um movimento de fortalecimento e onipotência do eu. O uso da droga como uma proteção contra o sofrimento e realidade (como apontado por Simmel), parece estar mais relacionada à função das drogas como "amortecedores de preocupações", como Freud aponta em 1930. Ou seja, evitar o desprazer e produzir prazer é a tônica do princípio do prazer, o que nos leva a pensar que aqui trata-se de uma modalidade de uso distinta da toxicomania, visto que esta está para além do princípio do prazer.

Ainda que de fato o narcisismo primário seja marcado por um período de onipotência do eu, no narcisismo secundário, essa onipotência há de ser parcialmente abandonada para dar lugar às interdições e identificações secundárias. A noção de que a toxicomania seria a tentativa de restaurar essa onipotência 
narcísica nos leva a seguinte questão: Se esse sujeito não foi submetido totalmente ao narcisismo secundário e, consequentemente, às interdições e leis morais (buscando essa onipotência narcísica), ele pode ser considerado neurótico? Faria sentido, metapsicologicamente, considerarmos as toxicomanias como neuroses narcísicas (como propôs Simmel) ou distúrbio narcísico (como considerou Radó)?

Caio de Mattos Filho (2009) comenta que a adolescência é um momento privilegiado para o uso de drogas, e as pesquisas epidemiológicas confirmam esse fato. As drogas possuem funções diversas na vida dos adolescentes, "como um agente socializador, na busca de ideais diferentes daqueles paternos; um recurso para o rompimento radical com o mundo e o mal-estar vivido nele; e como um objeto que permite o sentimento de potência imaginária em nome do narcisismo e contra a castração" (p. 176). Aqui aparece também a perspectiva da tentativa de atingir uma potência própria ao narcisismo, mas já associada a um movimento contra a castração.

Dias e Correia (2015) se debruçam sobre o estudo da organização social contemporânea e as implicações desta para a produção de sujeitos toxicômanos. As autoras, no entanto, classificam as toxicomanias como patologias narcísicas. A sociedade contemporânea possui um caráter narcísico, que exalta e objetifica o próprio eu. Sob esta ótica, o uso intensivo de tóxicos pode ser visto como uma tentativa de ingresso nessa cultura do espetáculo e valorização do eu.

Ribeiro (2009) comenta que, embora a toxicomania seja considerada por muitos autores como um sintoma contemporâneo relacionado à inflação narcísica e hedonista que predomina na sociedade atualmente, esses sintomas atuais (dentre eles a toxicomania) está mais ligado à destruição ligada às pulsões de morte do que uma exaltação narcísica. Levando em consideração o conceito psicanalítico de narcisismo, Ribeiro ressalta que a overdose é um movimento em direção à morte, ao aniquilamento do eu, enquanto o uso comedido seria uma forma de preservação narcísica, que está poupando o eu. A partir desse entendimento, a autora supõe que o conceito de narcisismo nos é útil para avaliar a modalidade de uso da droga, que pode ser recreativo ou destrutivo. De acordo com a percepção de Ribeiro, a posição narcísica do sujeito diante do uso da droga é diferente nos casos em que há uma preservação do eu e nas toxicomanias, nos quais o eu é lançado à morte.

Bento (2010) defende que as toxicomanias e as paixões tóxicas partilham alguns elementos em comum, em especial o excesso narcísico. O autor evoca a operação de phármakon explorada por Le Poulichet e já comentada por nós no capítulo anterior. Na operação, de acordo com Bento (2010), há um excesso narcísico e investimento no corpo real para lidar com a angústia ao 
invés de um investimento simbólico. Bento (2010), a partir de Le Poulichet, defende que na falta da substância, há um aumento das tensões que é sentido como intolerável e acompanhado de sentimentos de ameaça. Daí a o uso da substância é imperativo e faz parte dessa operação de phármakon que promove o que ele chama de reduplicamento narcísico, ou seja, um movimento no sentindo de retirar o investimento dos objetos exteriores e voltar para o eu, o que gera intoxicação. Como comentamos no capítulo anterior, essa operação de phármakon, explorada por Le poulichet em 1987, é uma operação de autoconservação paradoxal, pois à medida em que é utilizada como remédio, atua como um veneno, causando destruição.

Macedo \& Dockhorn (2014) consideram que a toxicomania pode ser vista, dentre outras coisas, como um "aprisionamento ao investimento narcísico do outro" (p.46). Nessa perspectiva, as falhas primordiais no período infantil suscitam em um comprometimento na constituição do narcisismo. Segundo os autores, a falta de investimentos amorosos por parte dos pais e também o fato deles não se oferecerem como registro de alteridade causa um abalo subjetivo no sujeito e no seu potencial simbólico. Essa visão sustenta a visão de um fator constitutivo que causaria um eu precário, sujeito à toxicomania, que é uma visão também adotada por outros autores.

A partir da noção de estádio do espelho formulada por Lacan, Olievenstein (1985) apresenta a teoria do estado do espelho partido, que seria uma etapa do desenvolvimento infantil capaz de levar uma pessoa a tornar-se toxicômano futuramente, ou seja, há, para ele, uma etiologia na constituição infantil. Segundo o autor, a saída no estado do espelho nesses casos não seria bem-sucedida, mas também não configura uma relação dual (própria do psicótico). O que ocorre, segundo Olievenstein (1985), é que este espelho é partido e, portanto, reflete parcialmente a imagem da criança e também as fendas deixadas. Essa imagem com a qual a criança se identifica é, portanto, fragmentada. Essas falhas do espelho mantém o momento da relação dual, onde há indiferenciação entre criança-mãe e, portanto, não há ainda uma identidade. O autor atribui um caráter constitutivo nas toxicomanias, mas não as inclui em uma estrutura específica, pois há elementos narcísicos, perversos e psicóticos aqui, o que, de acordo com nossa observação, se aproxima dos estados limítrofes (ou borderline).

Olievenstein (1985) comenta que a introjeção da droga no corpo pode ser considerada uma tentativa de reconstruir os pedaços desse eu fragmentado. Em relação ao aspecto perverso das toxicomanias, o autor compara o toxicômano à criança perversa polimorfa que possui um movimento de alucinar a realidade para anulá-la. A droga atua nesse sentido, de alucinar a realidade para anulá-la. 
A justificativa desse espelho "partido" está, segundo o autor, na inexistente ou inexpressiva presença paterna para "romper" a relação dual mãecriança, ou seja, ele se baseia na perspectiva de que se a castração e a lei do pai não forem eficientes, há uma tendência à transgressão das leis. Segundo Olievenstein (1985), o estado do espelho partido é sucedido pelo "estádio do exagero", que consiste em momentos de exageros e transgressões por falta dessa noção de limites. A toxicomania aparece como uma dessas formas de ultrapassar o limite, pois é um comportamento excessivo e com componentes perversos, mas é, sobretudo, um pedido por limites. O aspecto paradoxal dessa criança "candidata" à toxicomania também é apontada pelo autor:

Será que ressaltamos bastante o procedimento constantemente contraditório desta criança? Ela é "fusionada", e não o é; é Uma, e não é; joga, e não pode jogar; encontra o paraíso, e por isso sua queda é ainda mais dura; anula o tempo, e o tempo vivido lhe é infinitamente cruel. Se toda verdade provém do homem, é difícil imaginar onde estará a sua, já que a ela só cabe duvidar de tudo e de todos, e em primeiro lugar de si mesma enquanto Unidade (Olievenstein, 1985, p. 100).

A masturbação também aparece como elemento na teoria de Olievenstein quando ele comenta que ela aparece com uma importância desproporcional nessas crianças. Essa prática constitui em uma prática de acesso fusional ao corpo concreto. É uma forma de anular o corpo despedaçado e sentir prazer enquanto se sente um inteiro. Esse é um movimento que posteriormente será feito com as drogas.

De acordo com Pinheiro (2012), a experiência clínica mostra que o juízo de existência e de atribuição estão comprometidos em muitos desses pacientes. Os sujeitos são frágeis, vivem em profunda angústia e precisam de provas constantes de existência, como por exemplo através de sensações corporais. A autora afirma que o modelo histérico não dá conta de explicar o funcionamento dos toxicômanos (e de outras assim denominadas patologias narcísicas), porém aponta que essas organizações psíquicas difíceis de situar teoricamente possuem o traço depressivo como algo em comum.

\subsection{2 \\ Melancolia e os tóxicos}

Como demonstramos anteriormente, Ferenczi (1911) comenta que o alcoolismo é mais comum em sujeitos melancólicos, pois o álcool tem a função de lhes dar uma excitação endógena que lhes falta. Essa foi a mesma lógica que Freud (1987) usou quando apostou no caráter excitatório da cocaína para tratar a melancolia. Simmel $(1927,1947)$ e Radó $(1926,1933)$ teorizaram 
também sobre a toxicomania ser uma defesa contra a melancolia, já que gera uma mania artificial.

Pimenta, Cremasco \& Lesourd (2011) comparam a toxicomania e a melancolia ao afirmarem que ambas partilham da mesma fonte metapsicológica. Os autores afirmam que as drogas são utilizadas para preencher um vazio, mas que, entretanto, a "fissura" - sentimento de falta acarretado pela ausência da droga - é uma falta-a-ser que pode ser camuflada pela falta física da substância, e que o uso de drogas seria uma forma de incorporar o objeto e fixar-se a ele numa relação de dependência. O melancólico investe libidinalmente no objeto perdido incorporado ao eu e o toxicômano investe no próprio corpo idealizado restaurando, alucinatoriamente (a partir do uso de substâncias), uma imagem inteira de si. Ambos estão presos a um gozo aniquilante.

Caravelli (2005) também aproxima a toxicomania da melancolia quando defende que a tentativa de suprir um vazio diz respeito a uma perda narcísica fundamental ao sujeito, e há, na conjugalidade com a droga, a intenção de suplência ao "divórcio não consentido do sujeito com o primeiro Outro" (p. 19).

Conte (2001) apresenta alguns pontos para sua aproximação da toxicomania à melancolia. O estádio do espelho é apresentado como ponto da problemática melancólica, pois uma vez que a criança que não é olhada, esta não possui espelho para que se reconheça enquanto sujeito. Sua posição subjetiva é a de uma identificação com o vazio. Olievenstein (1985) comenta que no estádio do espelho quebrado - teorizado por ele e já comentado aqui - há uma vertente melancólica uma vez que as fendas no espelho partido geram o sentimento de incompletude devido à falta de reconhecimento. No entanto, ele não enquadra a toxicomania na melancolia, apenas aponta esse elemento existente nos casos.

A problemática da castração também é apontada por Conte (ibidem) com um ponto de convergência entre melancolia e toxicomania no sentido de que a tentativa de fuga da castração é o motivo de adoecimento do melancólico. O toxicômano elege a substância como único objeto importante, investe somente nele e desinveste em outros objetos. Enquanto há prazer e efeito, há uma ligação a esse objeto. Ela diz:

Pode-se pensar que, na toxicomania, assim como na melancolia, há uma tendência à equivalência dos objetos e que a droga tem valor positivo enquanto é possível desfrutar do seu Efeito. E, como decorrência, é possível formular que o toxicômano se desilude em relação à droga, e todos os objetos voltam a se equivaler, retornando à posição melancólica de origem? O toxicômano, no percurso de sua dependência, quando se desilude de seu investimento na droga, acaba por identificar-se com ela na posição de refugo, de resto, de lixo (Conte, 2001, p. 100). 
Fala-se também das toxicomanias como uma tentativa de autoconservação narcísica e tentativa fracassada de separar-se do Outro que acarreta em uma alienação ao Outro. Nessa perspectiva, o sujeito toxicômano não foi suficientemente investido e, portanto, possui identificações e seu eu fragilmente sustentados (Silveira, 2013).

Em 1917, Freud teoriza acerca da melancolia, e a define como forma patológica do luto, pois nela não há desligamento do objeto perdido. O eu se identifica com esse objeto perdido, então não há possibilidade desse luto ser elaborado (Freud, 1917/2010). Zimerman (2008) comenta:

A melancolia absorve algumas características do luto e outras do processo de regressão da escolha narcísica de objeto até o narcisismo. Freud enfatiza o quanto a característica mais notável da melancolia é sua tendência para transformar-se em mania, o que ele liga à regressão da libido até o narcisismo (p.254).

Mansilla \& Bento (2006) entendem a auto-destruição nas toxicomanias como melancolia e negação maníaca ao mesmo tempo. Essa percepção se dá a partir da noção de que a auto-destruição não é dirigida a si, mas ao outro que foi introjetado.

Enquanto melancólico, o toxicômano é um sujeito recolhido em si mesmo, caracterizando-se assim pelo excesso do investimento narcísico. Seu destino não poderá ser outro que aquele de Narciso do mito: a morte, o encontro com as pulsões de morte. Mas, havendo uma substituição da mãe pela droga, algum luto, apesar de tudo, deverá ocorrer, permitindo que se suponha a existência de algum simbolismo, de alguma elaboração, de alguma sublimação e, assim, da convocação das pulsões de vida psíquica (Mansilla \& Bento, 2006, p.15).

\section{2}

\section{Pulsão de Morte, Masoquismo, Destrutividade e as Toxicomanias}

Simmel $(1927,1947)$ foi o primeiro pós-freudiano a mencionar o caráter auto-destrutivo existente nas toxicomanias ao comentar que a agressividade que antes era dirigida aos objetos agora se voltava para o eu, que começava a se desintegrar. O autor inclusive utiliza o grau de desintegração do eu para classificar o grau de morbidez alcóolica. Bergeret (1982) comenta a violência natural que gera necessidade de auto-degradação. O caráter destrutivo aparece na teoria de Radó $(1926,1933)$ no sentido de a toxicomania destruir a organização natural do eu, que por sua vez fica impedido de perceber a auto-destruição causada pelos tóxicos. Rosenfeld (1960) fala da onipotência destrutiva presente no período de uso da substância e Glover (1928, 1932) aponta para um fator sádico na escolha de uma substância nociva. Vejamos de que forma o conceito de pulsão de morte (posteriormente elaborado por 
Freud) nos auxilia na análise dessas propostas e quais foram algumas das teorias posteriores baseadas nesse conceito.

Comentamos na seção anterior que, até 1915, Freud havia definido o conceito de pulsão e estabelecido dois tipos de pulsões: as pulsões do eu (ou de autoconservação) e as pulsões sexuais, e o conflito entre as duas seria causador das neuroses. Nessa perspectiva ainda vigorava a primeira tópica do aparelho psíquico e o princípio do prazer parecia regê-lo. Após a descoberta da libido narcísica a teoria sofreria algumas alterações, como a definição de um novo dualismo pulsional e uma segunda tópica do aparelho psíquico.

Na lógica econômica do princípio do prazer o aumento de tensão causaria desprazer e a redução causaria prazer ou evitaria o desprazer. Em seu artigo "Além do princípio do prazer", Freud (1920/2004) apresenta a ideia de que não é correto afirmar que o aparelho psíquico é exclusivamente regulado pelo princípio do prazer, pois os processos decorrentes de tal princípio acarretariam sempre no prazer, e a experiência mostra que tal fato não ocorre o tempo inteiro. Ao buscar eliminar o desprazer ou manter a excitação o mais baixo e constante possível, qualquer aumento da excitação seria tido como desagradável e, nessa perspectiva, pode-se dizer que o princípio do prazer é uma derivação do princípio da constância.

O que podemos afirmar, de fato, é que o aparelho possui uma tendência no sentido do princípio do prazer, ou seja, essa tendência é uma formulação do princípio do prazer e não necessariamente consegue cumprir sua meta, pois o objetivo é alcançável somente por aproximações. Ademais, Freud (1920/2004) observou que nos sonhos nas neuroses traumáticas, na transferência no tratamento analítico e na brincadeira infantil fort-da era possível observar uma repetição de momentos desagradáveis, o que o levou a investigar e reconhecer em alguns destes fenômenos um movimento para além do princípio do prazer.

É a partir dessas circunstâncias, que são de caráter pulsional - e concernem a uma compulsão à repetição - que Freud (1920/2004) levanta a hipótese de que as pulsões visam reestabelecer um estado anterior, fazer um retorno ao inorgânico, ou como o autor aponta: "O objetivo de toda vida é a morte" (p.49). É apresentado então o segundo dualismo pulsional, no qual Eros (ou pulsões de vida) visa manter todas as coisas unidas conservadas e se oporia às pulsões de morte. Ocorre que, enquanto as pulsões sexuais se dirigem aos objetos, as pulsões de autopreservação retêm a libido (narcísica, que é uma manifestação das pulsões sexuais), o que contradiz a ideia de oposição destas, proposta do primeiro dualismo pulsional, pois parte das pulsões do eu são sexuais e as pulsões sexuais operam no eu.

Quer dizer, as pulsões de morte, por incluírem as pulsões sexuais, 
tendem a se contrapor ao objetivo do organismo que é alcançar o estado inorgânico. Assim, é levantada a hipótese de serem voltadas para o interior (autodestruição) e para o exterior (agressão ou destruição) - situações nas quais visam destruir o objeto. Uma parte das pulsões de morte age em função do sexual, o que é chamado no momento de sadismo, e outra parte permanece no organismo, onde está ligada libidinalmente e resulta no que é chamado de masoquismo. Foi com esta observação que Freud (1920/2004) concluiu que a compulsão à repetição é independente ao princípio do prazer, o que o levou a investir na formulação das pulsões de morte, as quais seriam servidas pelo princípio de nirvana, que visa reduzir a quantidade de excitações a zero.

O instinto reprimido nunca deixa de esforçar-se em busca de satisfação completa, que consistiria na repetição de uma experiência primária de satisfação. Formações reativas e substitutivas, bem como sublimações, não bastarão para remover a tensão persistente do instinto reprimido, sendo que a diferença de quantidade entre o prazer da satisfação que é exigida e a que é realmente conseguida é que fornece o fator impulsionador que não permite qualquer parada em nenhuma das posições alcançadas (Freud, 1920/1996, p.52/53).

As pulsões de conservação, fenômenos da vida, visam, na verdade, que o organismo alcance a morte através de meios naturais, por meios do próprio organismo e, portanto, afastam todo e qualquer perigo que possa "acelerar" esse processo por outros meios. As pulsões sexuais visam uma "imortalidade potencial" no sentido do alongamento da estrada para a morte a partir da reprodução, uma função das pulsões sexuais. Nesse momento de sua escrita, Freud (1920/1996) traz as pulsões de vida enquanto conservadoras da vida e as pulsões de morte enquanto pulsões de ordem destrutivas e que visam a morte. Essas pulsões são classificadas como opostas e rivais, mas veremos que não é disso que se trata.

Em 1925 Freud investiga a origem da função do juízo, que possui a atribuição de qualidade de representação real a algo. O juízo de atribuição, que confere qualidade a algo pode ser pensado a partir do eu-prazer, que quer introduzir o que é bom e expulsar o que é ruim. Hyppolite (1954/1998) ressalta que o movimento de introjeção e expulsão que originam essa tarefa da função do juízo diz de uma alienação primordial, de um sujeito que, miticamente, não estranhava nada e que, a partir de uma operação de expulsão pôde distinguir o estranho de si mesmo. Garcia-Roza (2003) nos alerta que esse estado afetivo primordial no qual a criança é dominada pelo sim e, por não poder negar pela linguagem, recalca a afirmação original, é de ordem mítica, visto que não existe afetivo puro, pois a criança já nasce inserida no mundo de linguagem e marcada pelo simbólico (Freud, 1925/2011). 
Ao eu-realidade interessa o juízo de existência, que confere a algo representação na realidade. Essa função continua na esfera do interno-externo, visto que o que existe apenas como representação subjetiva, o não-real, encontra-se "dentro" e, aquilo que possui representação real está "fora".

A relação entre representação e percepção origina o juízo de existência, mas essa representação na realidade não se trata de um encontro de objeto real, mas sim de um reencontro, levando em consideração que representações são repetições de percepções, ou seja, percepções reais levam a representações que se repetem e garantem a realidade representada. Nesse sentido, o princípio do prazer não se faz capital, visto que a repetição é por onde o juízo de existência verifica tanto a percepção quanto a representação, sendo constitutiva.

Freud (1925/2011) passa a supor, então, que a origem do juízo está nos impulsos pulsionais primitivos. O movimento de inclusão ou exclusão, que se dava pelo princípio do prazer, é sucedido pelo juízo intelectual. Nessa perspectiva, o par de forças (de atração e expulsão) que compõe essas duas funções do juízo é associado pelo autor com seu recém-apresentado segundo dualismo pulsional. A afirmação substituiria a Eros (em sua tendência unificadora) e a negação sucederia as pulsões de morte (em seu caráter destrutivo). As pulsões de morte, que haviam sido apresentadas como pulsões que visam um retorno ao inorgânico passam a ter como estatuto um caráter disjuntivo e, sua sucessora, a negação, deve ser entendida como disjunção de componentes libidinais e independente do princípio do prazer e das consequências do recalque, tendo, segundo Hyppolite (1954/1998, p.896), a "função de gerar a inteligência e o próprio posicionamento do pensamento".

Green (1984/1986, p. 57) nos propõe que "a função autodestrutiva desempenha para a pulsão de morte um papel correspondente àquele que desempenha a função sexual para Eros", porém, o autor diverge de Freud em relação à autodestruição como expressão fundamental, isto é, ao masoquismo originário, à medida em que afirma que nem toda destruição é de ordem sexual.

O referido autor propõe uma hipótese na qual a meta vital das pulsões de vida seria a função objetalizante, onde não só haveria a criação de uma relação com objetos internos e externos, mas que também, a partir do investimento significativo, tornaria qualquer indivíduo em objeto, inclusive o próprio investimento. Nessa perspectiva, o objeto e a função objetalizante podem ser discriminados pela ligação, o que leva o autor a criticar algumas teorias que se apegam unicamente ao objeto (Green, 1984/1986).

Ao contrário de Eros, que pela ligação tem como meta a função objetalizante, as pulsões de morte teriam, de acordo com a hipótese de Green (1984/1986), uma função desobjetalizante que, pelo desligamento, atua no sen- 
tindo de desinvestir não apenas nos objetos, mas no próprio eu e no investimento que uma vez foram objetalizados. Ao passo que a função objetalizante trabalha com transformação de objetos e deslizamento, a função desobjetalizante, meta das pulsões de morte, trabalha contra esse movimento. É a partir dessa construção que Green concebe a passagem da libido objetal para libido narcisista e defende o conceito de Narcisismo negativo enquanto expressão da função desobjetalizante sobre o processo objetalizante e com pretensões ao "nível zero" (Green, 1984/1986, p.61).

Serreti (2012) se baseia na proposição de Green sobre a função objetalizante e desobjetalizante das pulsões de vida e de morte, respectivamente, para afirmar que a pulsão de morte é responsável por desorganizar as funções psíquicas do toxicômano. Essa proposta se baseia na teoria Greeniana na qual a meta da função objetalizante das pulsões de vida é realizar a simbolização. Veremos adiante que esse processo de simbolização não ocorre na compulsão à repetição existente nas toxicomanias.

A pulsão de morte, no entanto, pode ser analisada enquanto conceito capital para a gênese de processos psíquicos e da constituição, ou como Oliveira; Winograd \& Fortes (2016, p.69) colocam, fonte de uma "negatividade necessária e fundamental para os processos de subjetivação". Como as autoras apontam, a destrutividade da pulsão de morte seria uma consequência da luta pela sobrevivência e não uma autodestrutividade intrínseca, pois, como já comentado, as pulsões de morte são necessárias, posto que um "excesso" das pulsões de vida sobre as de morte seria, de certa forma, mortífero.

Essas considerações vão de encontro com o caráter paradoxal da operação de phármakon que, numa tentativa de autoconservação, acaba gerando destruição para o sujeito que utiliza as drogas como remédio. Nesse sentido seria válido supor que a função desobjetalizante das pulsões de morte, de acordo com a perspectiva de Green, teria uma função (por consequência) benéfica em relação ao objeto droga do toxicômano, pois desinvestiria nesse objeto mortífero?

Mansilla \& Bento (2006) acreditam que a drogadição é fruto de uma ação das pulsões de morte e das pulsões de vida juntas, pois além da autodestruição e descarga da pulsão, há também, no ato toxicomaníaco, uma tentativa de elaboração. Para os autores, a toxicomania simboliza uma perda fundamental através dos atos. É um ato que ao mesmo tempo silencia e "fala", ou como afirmam: "Ela estaria assim situada num lugar intermediário entre a brincadeira infantil e o ideal de cura analítica pelo acesso ao simbólico através do luto pela perda original" (p.27).

Em "O problema econômico do masoquismo", Freud (1924/2011) co- 
menta um impasse que aparecera em 1920, período no qual o autor postulou seu segundo dualismo pulsional. Se na questão do masoquismo a dor e o desprazer viram objetivos, o princípio do prazer é "como que narcotizado" (p.195). Ele postula três tipos de masoquismo: o erógeno (prazer sexual através da dor), o feminino (prazer pela fantasia de estar em uma posição feminina) e o moral (dor por sentimento de culpa, ligado ao castigo). Em seu texto sobre as pulsões, Freud (1915/2004) havia comentado que o masoquismo seria o sadismo voltado para o próprio eu, mas em 1920, após cunhar o novo dualismo pulsional, ele modifica um pouco essa explicação.

A fim de evitar que as pulsões de morte atinjam seu objetivo de reestabelecer um estado inorgânico, a libido desviaria as pulsões de morte para os objetos externos, o que dá origem às então chamadas "pulsões de destruição". Uma parte dessas pulsões está a serviço do sexual, o que consiste no sadismo, assim denominado por Freud. Parte dessas pulsões não é direcionada para fora e fica retida no sujeito. Ligadas libidinalmente, essas consistem no que Freud chamou de masoquismo original. Uma vez que as pulsões de destruição foram em direção aos objetos externos, estas também podem retornar para o eu, e a esse movimento Freud nomeou de masoquismo secundário.

É importante ressaltar que existe uma diferença entre o masoquismo moral e o sadismo do supereu, apesar de ambos tratarem da relação Eu-Supereu e da necessidade punição. O masoquismo moral aspira castigo oriundo de qualquer instância ou poderes externos, enquanto uma continuação inconsciente da moral, que intensifica o sadismo do Supereu imposto ao Eu de forma cruel. Freud (1924/2011) nos alerta que "Consciência e moralidade surgiram com a superação, a dessexualização do complexo de Édipo; com o masoquismo moral, a moralidade é novamente sexualizada, o complexo de Édipo é revitalizado, abre-se o caminho para regredir da moralidade ao complexo de Édipo" (p. 200). Nessa perspectiva, o masoquista age de forma auto-destrutiva a fim de provocar o castigo por algum representante substitutivo das figuras parentais.

A repressão dos instintos, imposta pela cultura, também faz com que as pulsões destrutivas, ao invés de direcionadas para o exterior, apareçam como intensificadoras do masoquismo. Já as pulsões que retornam do exterior e intensificam o sadismo do supereu. Ambos se complementam e suscitam no sentimento de culpa e necessidade de punição. É importante frisar que o masoquismo moral provém das pulsões de morte e, evidentemente, dispõe de elementos eróticos, ou seja, essa auto-destruição também desfruta de certa satisfação libidinal. Esse fundamento tem relação com o conceito de gozo, que comentaremos posteriormente.

Ao teorizarem sobre as toxicomanias, Simmel (1927, 1947) e Bergeret 
(1982) apontaram a existência de uma agressividade natural que, ao invés de ser direcionada para o exterior, é voltada para o eu. Essa teoria aproximase da noção de masoquismo original, no qual as pulsões de morte, ligadas libidinalmente, permanecem no sujeito ao invés de serem direcionadas para o mundo externo, e essa permanência produz auto-destruição. Já a noção de Glover $(1928,1932)$ de que existe um fator sádico na escolha do objeto nocivo já nos remete à necessidade de punição e sentimento de culpa que podem ser oriundos tanto do masoquismo moral quanto do sadismo do supereu.

Simmel atribui essa ação destrutiva ao supereu, apesar de afirmar que o efeito do álcool, por exemplo, suspende seus efeitos. Como comentamos, o sadismo do supereu tem relação com o masoquismo secundário, ou seja, com as pulsões de destruição que, uma vez voltadas para os objetos externos, retornam para o sujeito e intensificam o sadismo do supereu em relação ao eu. É importante ressaltar que a necessidade de punição e sentimento de culpa não são apenas frutos de um supereu severo e crítico, mas, como já comentamos, as pulsões de destruição que atuam no eu (de forma primária ou secundária) são dotadas de elementos eróticos. Há, portanto, um fator satisfatório nessa ação, apesar de também haver sofrimento. Essa ordem de usar substâncias - ordem de caráter auto-destrutivo - também pode ser considerada um movimento em nome do gozo. Nesse sentido, não nos parece razoável que, a mesma instância que determina o uso seja, ela mesma, "solúvel no álcool".

Mendonça (2011) menciona que o supereu aparece como uma instância normatizadora no primeiro dualismo pulsional, mas que a partir do segundo dualismo se mostra a serviço da pulsão de morte e da destruição através da exigência pulsional, do imperativo de gozo. Ou seja, se, na ótica do primeiro dualismo, o recurso aos tóxicos visava amenizar a severidade do supereu, no segundo dualismo esse uso está a serviço dele.

Nespoli, Novaes \& Madureira (2018) comentam que, nas compulsões, "o sujeito relaciona-se com seu objeto a partir da submissão deste à supremacia superegoica" (p.93). O que ocorre nesse processo é que a compulsão à repetição que existe no imperativo de gozo imposto pelo supereu leva o sujeito a sucumbir a um sofrimento que o aprisiona. Esse processo é observado com frequência na relação do toxicômano com sua substância.

\section{3}

\section{Da Necessidade ao Desejo, da Compulsão à Repetição ao Gozo}

A formulação do aparelho psíquico regulado pelo princípio do prazer se dá a partir da compreensão de que na situação do bebê, infans - que vem ao mundo no desamparo e descarrega energia pelo choro, devido a alguma 
excitação interna (devido à fome, por exemplo) - há um cessar dessa excitação interna somente no momento em que a mãe, por exemplo, acolhe e nutre o filho, oferecendo a ele um objeto de satisfação, e não através de descarga motora (chorar, gritar), como o modelo propunha (Freud, 1900-1901/1996).

A esse momento de acolhimento dá-se o nome de "primeira vivência de satisfação", que é mítica, posto que nesse instante, uma imagem mnêmica é associada ao traço da excitação produzido pela necessidade, gerando um vínculo. Quando houver um excesso de excitação, haverá desprazer. O desejo, para Freud (ibidem) parte do desprazer e aponta para o prazer, é o que coloca o aparelho em movimento e está na busca pela marca que provocou alucinação. Em suma, a necessidade se satisfaz em um objeto real, e o desejo, ligado aos traços de memória, se satisfaz através do sonho ou de forma alucinatória.

Lacan (1964/2008) traçou a diferença entre necessidade e desejo e também cunhou o termo demanda para se referir à demanda de amor dirigida a outrem. O desejo visa experimentar aquele prazer que vem acompanhado do gozo. Lacan situa o desejo como o investimento que resta e não consegue se representar, na busca de um significante que diga ao falante quem ele é, ou seja, o desejo é desejo do outro. É consequência da faltas e falhas. Situamos que o sujeito que se constitui em torno da falta é o sujeito neurótico.

É importante ressaltar que a demanda está relacionada a um desejo insaciável, pois o objetivo de preencher o vazio de um objeto faltante é inalcançável. A demanda é, senão, um pedido de amor e reconhecimento, ou seja, tem origem narcísica. Zimerman (2008) afirma que "na demanda, há o desejo de ser o único objeto do outro. No entanto (...) esse objeto ideal é eternamente faltante, não podendo o desejo do sujeito jamais ser nomeado e circulará (sob a forma de metonímias) de um significante para outro" (p. 98). Nesse sentido, alguns comportamentos compulsivos de consumo podem ser considerados uma busca por preenchimento desse vazio que aponta para questões existenciais.

Há circunstâncias que impedem que o aparelho psíquico cumpra com a finalidade do princípio do prazer, e isto se deve ao princípio da realidade e ao recalque. Devido ao princípio da realidade adiar a satisfação, abandonase a possibilidade de tê-la e torna o desprazer tolerável temporariamente em nome do caminho longo e indireto para o prazer. O processo do recalque ocorre quando pulsões vão, repetidamente, ao encalço de metas insuportáveis. Caso em que outras pulsões cujas metas são passíveis de integração entram em jogo, visando uma unidade do "eu", ou seja, atuam para que aquelas insuportáveis não alcancem o "eu".

Essas pulsões ficam, à priori, impossibilitadas de satisfação. Porém, a 
partir de desvios, podem alcançar satisfação direta ou substitutiva, o que gera prazer para uma instância - Isso, e desprazer para o "eu", e, leva à premissa de que "todo desprazer neurótico é desta espécie: um prazer que não pode ser sentido como tal" (Freud, 1920/2004, p.138). A condição do sujeito falante é a falta, portanto está fadado à insatisfação. Não há como obter satisfação através de um objeto da realidade, apenas escamotear certo investimento pulsional.

A supracitada brincadeira infantil "fort-da" ilustrada por Freud em 1920 mostra que, diante da falta real da mãe, a criança usa uma representação da renúncia em relação a sua partida e que, diante dessa partida, a criança cria essa brincadeira do desaparecimento e do retorno a partir dos objetos próximos. O fort (desaparecimento), porém, aparece repetido inúmeras vezes em relação ao $d a$ (aparecimento dos objetos), então surge o questionamento do motivo da repetição de um momento desagradável em detrimento de um prazeroso (aparecimento). Concluímos, neste momento, que a repetição dessa vivência desagradável em forma de brincadeira se dá em decorrência de um prazer imediato - a criança é o agente da ação - vindo da relação com outrem.

A relação entre o princípio do prazer e a compulsão à repetição foi estabelecida aqui na busca irrestrita por satisfação, contudo, a compulsão à repetição causa desprazer à medida em que o expõe moções pulsionais recalcadas. O que o "fort-da" de Freud (1920/2004) nos mostra é que ao repetir o desagradável, o sujeito se oportuniza mudar tal destino que não contradiz o princípio do prazer. A partir dessa observação, Freud (ibidem) nota que a compulsão à repetição traz também atividades que jamais proporcionaram prazer a nenhuma outra instância, fato que o leva a reconhecer um além do princípio do prazer. A compulsão à repetição que também repete momentos de dor está a serviço das pulsões de morte, que como já comentamos, busca retornar a um estado inorgânico.

Pode-se pensar a repetição a partir de algumas perspectivas, como no contexto mítico da afirmação primordial, no qual a negação tem como agente a mãe que, ao sair de cena dá lugar à diferença que suscita o sujeito. A perda do objeto real fornece a distinção do eu-objeto, do real para o alucinado, e esse processo que se dá pela pulsão de morte é responsável, nesse sentido, pela repetição que visa o reencontro do objeto. Em outras palavras, tenta reinvestir na imagem mnêmica, restabelecer a primeira vivência de satisfação e reencontrar a falta, já que o primeiro desejar é um investimento alucinatório, um investimento sem objeto (o Das Ding, objeto "perdido", portanto inapreensível) que, dado seu caráter de constância, buscará objetos parciais para cessar a necessidade e produzir satisfação. Em relação à pulsão, Lacan (1964/2008, p.165) coloca que “[...] não é pelo alimento que ela se 
satisfaz, é como se diz, pelo prazer da boca".

A partir daí compreendemos que $\mathrm{O}$ eu-real satisfaz o princípio do prazer naquilo que diz respeito ao investimento sexual sendo que por sua condição inapreensível deixa uma lacuna a qual chamamos de sujeito. "O sujeito nasce no que, no campo do Outro surge o significante. Mas por este fato mesmo, isto - que antes não era nada senão sujeito por vir - se coagula em significante" (Lacan, 1964/2008, p. 194).

Tendo em vista que o trauma insiste em se fazer lembrar mesmo nos processos primários, onde os significantes existem numa rede, Lacan (1964/2008) contesta a ideia de que o trauma deve ser tamponado pela constância, proveniente do princípio do prazer, pois a repetição é uma tendência estabelecida pela condição de sujeito.

Em seu Seminário 11 (Os quatro conceitos fundamentais da psicanálise), Lacan (1964/2008) aborda o tema das repetições a partir de dois termos: tiquê e autômaton. A tiquê é o encontro com real, e ela se apresenta através do trauma, que é como o real costuma se apresentar a nós. O sonho, por exemplo, portador de desejos, repete traumas (e essa observação feita por Freud o levou a postular o conceito de compulsão à repetição além do princípio do prazer). O aparelho psíquico tenta tamponar os traumas, mas estes insistem em se fazer lembrar, escapam. São nesses momentos que o real se mostra como trauma, como algo inassimilável. Esse encontro com o real, a tiquê, é um encontro essencialmente faltoso. O real vai do trauma à fantasia, que dissimula algo determinante na função da repetição. Ele é irrepresentável.

O autômaton é o conceito que se assemelha àquilo que Freud chamou de compulsão à repetição, articulado por ele com a pulsão de morte. Lacan (1964/2008) retoma o tema da brincadeira fort-da na perspectiva de que, a criança, que se torna o agente do desaparecimento da mãe na brincadeira, não vigia o local (porta) por onde sua mãe partiu e por onde pode voltar, mas sim o local no qual foi abandonado. A leitura de Lacan é que o carretel não é a mãe reduzida, mas algo do sujeito que se destaca, que pertence a ele e que ele agarra. A repetição não é do pedido do retorno da mãe, mas sim da saída da mãe, que faz uma marca no sujeito, e uma alternativa em relação a essa saída, é uma espécie de resposta do sujeito àquilo que a falta da mãe gerou.

A hiância introduzida pela ausência desenhada, e sempre aberta, permanece causa de um traçado centrífugo no qual o que falha não é o outro enquanto figura em que o sujeito se projeta, mas aquele carretel ligado a ele próprio por um fio que ele segura - onde se exprime o que, dele, se destaca nessa prova (Lacan, 1964/2008, p. 66)

O significante é a primeira marca do sujeito, e o objeto carretel, nessa dinâmica, é algo do sujeito. Seguindo a lógica aristotélica, Lacan (1964/2008) 
afirma que "o homem pensa com seu objeto" (p.66). Esse objeto ao qual nos referimos é o objeto a.

A cadeia de significantes que determina a repetição é o autômaton, ou seja, o sujeito encontra-se entre esses significantes que o determinam, e nesse lugar simbólico se situa o Outro. A relação do sujeito com o Outro pode ser ilustrada com o esquema z apresentado por Lacan no seminário 4 (195657/1995). O Outro devolve a mensagem inconsciente do Sujeito de forma invertida, e essa mensagem é interditada ou deformada pela relação alienante do eu (a) com o outro (a').

A fantasia primeira é o que determina essa condição de repetição. Algo tem lugar de representação na falta, e o real está por trás dessa falta de representação. A tiquê está para além das voltas, do Autômaton, da rede de significantes, que determina essa repetição. O real é o obstáculo do princípio do prazer, é o que retorna sempre ao mesmo lugar, lugar onde o sujeito, na medida em que cogita, não o encontra.

O real se distingue (...) por sua separação do campo do princípio do prazer, por sua dessexualização, pelo fato de que em sua economia, em seguida, admite algo de novo, que é justamente o impossível (Lacan, 1964/2008, p.165).

O uso de tóxicos pode estar situado em uma relação alienante com o objeto droga, e a ausência da substância, provocada pelo usuário na abstinência, trata-se de uma falta real e não da falta simbólica, pois na relação alienante não há essa mediação simbólica na qual o Outro aponta para a falta do sujeito desejante. Visto que o sujeito advém no real, é através da tiquê, esse encontro faltoso com o real, que pode haver uma simbolização que só pode ser feita pela fala.

Cabe fazermos uma breve menção à diferença entre os conceitos de prazer e gozo, uma vez que estamos nos debruçando sobre as toxicomanias. O prazer está a serviço do princípio do prazer e se satisfaz com um objeto, enquanto o gozo está relacionado com o desejo, que é articulado com a falta de objeto e remete à falta estrutural do sujeito. A repetição torna patente a falta de um objeto que venha fazer frente à errância desejante do sujeito. Não há nenhum objeto que possa responder ao desejo.

É dessa falta de objeto que decorre o impossível na satisfação. Mas esse impossível é tomado sob a forma de um interdito, pois o campo próprio do desejo é aquele da falta de objeto que é tomada como perda. Trata-se aí da vigência de uma lei que barra o acesso ao suposto objeto que propiciaria satisfação plena.

A formulação do desejo como imposição da dimensão da falta no sujeito confrontada com a insistência repetitiva no reencontro com os fragmentos 
metonímicos do objeto perdido, é que coloca em cena esse outro conceito, em relação ao qual o próprio desejo aparece como o que lhe faz limite. Esse referido conceito é o de gozo. É Lacan (1957-1958/1999) quem nos diz que o manejo da noção de desejo carrega em si, de maneira implícita, a ideia de gozo, ideia que do desejo precisa ser distinguida, como outro polo.

Se a despeito da falta de objeto, o aparelho, em seu automatismo, visa na repetição a busca pela satisfação, ainda que alucinatória, satisfação que é impossível, pode-se dizer que visar o reencontro com o que está perdido é um movimento que denuncia certa retração em relação à própria perda de objeto. A insistência em se preencher, em se satisfazer completamente é o que nos aparece como gozo. O conceito de gozo, trabalhado por Lacan em sua obra, possui algumas ramificações e possui maior complexidade do que aqui comentamos. Não é nosso objetivo, no entanto, aprofundarmos nesse ponto, visto que priorizamos outros conceitos. Vejamos de que forma os autores contemporâneos trabalharam os conceitos citados nessa seção em sua articulação com as toxicomanias.

\subsection{1}

\section{As Toxicomanias e a Articulação com a Compulsão à Repetição e ao Gozo}

Melman (2005/2008) faz um retorno ao fort-da para explicar sua hipótese em relação às toxicomanias. Ele comenta que, na brincadeira, a criança lança o objeto preso a um barbante para fazê-lo retornar, ou seja, o objeto é aquilo que ela não pode largar. A castração opera fazendo um corte nesse barbante, que faz com que o objeto (a mãe) seja perdido definitivamente, e sua necessidade transformada em desejo. Esta formulação faz relação com o fato de que, nas toxicomanias, o uso de substâncias não está pautado apenas no princípio do prazer. Há uma repetição não apenas do uso abusivo de substâncias, mas da falta dela.

Existe uma dinâmica própria no uso da substância, na qual o toxicômano promove a abstinência ao utilizar toda a droga em pouco tempo. Isso diz respeito ao objeto que ele não consegue renunciar. De acordo com Melman (2005/2008), a relação objetal está em evidência no toxicômano, e sua dependência diz respeito a um objeto "cuja presença e verificação de sua presença se tornam indispensáveis à existência, com a alternância de fases de extinção da consciência graças a esse objeto, e outras, essas fases ditas de falta" (p.170-171).

Essa dinâmica uso-fissura, própria da compulsão à repetição, é comparada por alguns autores pós-freudianos como Radó (1926, 1933), Simmel (1927, 1947), Fenichel (1945) e Rosenfeld (1960) com o ciclo maníaco-depressivo ao 
passo que, diante de uma depressão, a droga entra fornecendo uma mania artificial que deixa o sujeito num estado de euforia e tomado por um sentimento de onipotência.

Alberti, Inem \& Rangel (2003) também comentam essa relação alegando que

Os pólos maníaco e depressivo da experiência psíquica toxicômana ocorrem em função da ingestão da droga, ou seja, secundariamente à drogadição, com efeitos que levam o sujeito a velar a castração - a mania - e sua contrapartida, o cessar desses efeitos, que revela o fracasso de sua tentativa - a depressão (p.15).

Olievenstein (1985) comenta que a alteração entre o estado high e down do toxicômano se assemelha ao ciclo maníaco-depressivo e, a predominância do excesso também se mostra uma semelhança entre ambos, pois a excitação maníaca e a depressão são sentidas com intensidade bem elevada. O autor, entretanto, alerta que "a dependência não pode tampouco ser reduzida a um fenômeno de condicionamento passivo ou associativo, e deve ser vista (...) como tentativa de reconstituir o ciclo, a unidade da própria pessoa" (p.25).

Arteiro \& Freire de Queiroz (2011) comentam o caráter insaciável do toxicômano em relação ao uso da droga. O intervalo de uso (especialmente de crack) costuma ser curto, havendo um imperativo para o uso constante. Nas palavras das autoras "a 'fissura' não se encerra, como se nunca fosse possível um "prazer completo"” (p. 1593).

O prazer completo de fato não é possível. O que está colocado, nesses casos, é que a droga toma um lugar primordial dentre os objetos parciais e impele o sujeito a um uso compulsivo, uma repetição. A repetição visa o reencontro com o objeto perdido, que na verdade é lugar de vazio, pois não há objeto. Os objetos parciais permitem certa satisfação, mas a satisfação e o objeto visados pelo desejo nunca serão viáveis.

Rodrigues (2012) menciona que a crise de abstinência é, na verdade, uma crise de angústia. Nesse sentido, o tóxico entra para aliviar essa experiência de angústia.

O ato toxicomaníaco constitui uma forma através da qual se tenta lidar com a ausência de objeto, com o vazio que nos concerne e de que a angústia é sinal, por uma via diversa daquela estabelecida pelo compromisso sintomático, tornando-se, não raramente, a maneira majoritária através da qual o sujeito faz frente ao desamparo primordial (...). A prática da droga surge como uma alternativa por meio da qual a pulsão se satisfaz circunscrita ao real do corpo. Evitando, assim, a irrupção da angústia e o conseqüente estado de urgência psíquica a que se encontrará o sujeito caso não disponha do recurso tóxico (p.82). 
A pulsão de morte, enquanto força disruptiva, pode ser responsabilizada por gerar um resto que não se inscreve, e a repetição pode ser pensada como forma de elaboração, tentativa de inscrição desse resto.

Nesse sentido, Pereira \& Migliavacca (2014) comentam que na toxicomania "o prazer do efeito da droga relaciona-se com o desprazer, a angústia e autodestruição, essa última comandada pela pulsão de morte" (p.73).

Ávila (2010) comenta que na toxicomania há um gozo auto-erótico, ao passo que tenta recriar corpo unido, mas também um gozo mortífero, que aponta para a autodestruição e pulsão de morte. A tentativa é de alcançar o gozo primevo, essa experiência mítica.

Serretti (2012) comenta que a pulsão de morte atua no psiquismo do toxicômano de forma silenciosa, o levando a uma compulsão à repetição e prejudicando seu psiquismo em busca da tentativa de reconstruir o sujeito do narcisismo primário, onipotente e inteiro.

Visto que a repetição é inerente ao funcionamento psíquico e que não há possibilidade, enquanto ideal terapêutico, de inscrever esse resto, questiona-se de que forma pode-se realizar um trabalho analítico nesse contexto.

Pacheco Filho (2007) propõe enxergar o toxicômano como modelo ideal de consumidor do capitalismo devido a sua prática regida pelo imperativo de gozo, que encontra impulso diante das condições de violência real e simbólica presentes na realidade brasileira. A droga, esse objeto real, se coloca como produtora de gozo, o que ofusca a falta estrutural. O autor argumenta que as drogas sempre tiveram seu lugar na cultura, mas a cultura capitalista fundada no imperativo do consumo afeta o modo e a intensidade do consumo de drogas.

Andrade (2001) identifica a toxicomania como uma das novas formas de sintoma e novas figuras de gozo que se apresentam na sociedade. As mudanças no mundo apresentam novos significantes que servem ao sujeito como objeto de gozo. Este, por sua vez, busca novas formas de se haver com seu sintoma. O autor afirma, ainda, que a toxicomania é um sintoma paradigmático do discurso capitalista, no qual o gozo prevalece sobre o desejo. Essa nova forma de gozar é colocada como um paradigma do capitalismo porque do consumo da droga decorre a anulação do sujeito.

Max e Danziato (2015) seguem esse raciocínio, supondo que "a constituição e o estatuto atual do mercado da droga, incluindo seus efeitos de dessubjetivação, estão relacionados ao movimento discursivo e aos desdobramentos do que Lacan nomeou como discurso do capitalista" (p. 423). Os autores consideram que o toxicômano é contemporâneo ao homo oeconomicus, visto que a produção e capitalização das drogas está a serviço do gozo, e a dependência a esse objeto, por sua vez, se apresenta como um sintoma do laço social 
contemporâneo.

Alba de Almeida (2010) ressalta que, diante do Outro do capitalismo, o sujeito aceita tudo e se faz de objeto do gozo perverso deste. O sujeito é capaz de abrir mão de tudo para usar mais a droga, e nesse comércio fica excluído da mais-valia. Seus bens materiais, aliás, são dilapidados em nome do imperativo do gozo comandando por esse Outro do capitalismo.

Giacoboni (2012) nos fala que a forma de consumo capitalista é semelhante à forma de consumo desenfreada na toxicomania, onde há uma busca pela total satisfação, tentativa de eliminação do mal-estar e recobrimento da falta através de objetos. A referida autora ressalta que "A toxicomania parece ser uma patologia que encena a compulsão social de consumo, evidenciando sujeitos que padecem diante da solidão na busca de ideais e identificações que atribuam sentido à sua existência" (p. 40). As práticas capitalistas da sociedade contemporânea enfatizam a alienação e assujeitamento aos objetos como única forma de ser.

Os autores acima demonstram uma perspectiva em comum: o foco no gozo presente nas toxicomanias que se articula com o gozo enquanto um imperativo do capitalismo e da modernidade. O caráter social ganha importante papel nessas perspectivas, que compreendem a toxicomania como um sintoma social que se articula com o sintoma do sujeito, diferentemente de perspectivas que apontam a etiologia na constituição infantil intra-psíquica do sujeito.

\section{4 Objeto Droga e as Toxicomanias}

Tomamos o ponto central nesse momento o recurso às substâncias tóxicas, a relação entre seu consumo e a experiência de prazer e para além do prazer que as mesmas proporcionam. Podemos supor que o toxicômano, sob o olhar da teoria psicanalítica, nos mostra com sua insistência ao uso de substâncias tóxicas, isto é, pelo apelo a um objeto, sua busca por vivenciar experiências de prazer, justamente uma compulsão, uma repetição que visa ao prazer imediato. Acreditamos tratar-se de um recurso que o sujeito usa para lidar com a falta que o constitui.

A relação do sujeito com o vinho é comparada por Freud (1912/2017) à relação do sujeito com seu objeto sexual com a seguinte diferença: com o objeto sexual (parceiro) o sujeito nunca consegue alcançar uma satisfação plena. Na perspectiva dele, a relação do bebedor com o vinho é plena e satisfatória, diferente de uma relação amorosa. Essa questão não é esclarecida, mas na lógica dos objetos parciais ambos cumprem a mesma função, que é de satisfazer as 
pulsões sexuais e servir de substituição de um objeto originário.

Freud (1898/1996) aproxima o vício em tóxicos às neurastenias quando ressalta a sexualidade na etiologia das neuroses atuais. Nesse contexto, ele comenta que os narcóticos visam a substituição da falta de satisfação sexual, mas que nem todos que entram em contato com esses tóxicos desenvolvem um vício. Diante de uma angústia, a prática da masturbação ou uso de tóxicos é realizada visando a satisfação.

Em "O mal-estar na civilização", as drogas são apontadas como objetos paliativos para lidar com o sofrimento. Nesse contexto, as drogas cumprem a função de objetos parciais e seguem a lógica do princípio do prazer, que visa evitar o desprazer e obter satisfação (Freud, 1930/2017).

A toxicomania, no entanto, implica, necessariamente no uso compulsivo de um objeto elegido pelo sujeito que o utiliza. A relação entre o sujeito e esse objeto se torna uma espécie de prisão, na qual o sujeito vira objeto de seu próprio objeto, como apontado por Pages-Berthier (1993).

Como já comentamos, no auto-erotismo o corpo da criança é o próprio objeto de seu investimento, através do qual as pulsões sexuais se satisfazem em zonas erógenas. Posteriormente, o investimento é voltado para os objetos externos. O que nos chama atenção nas toxicomanias é que, apesar do objeto droga ser um objeto externo, ele é introjetado no corpo, provocando sensações de prazer nele próprio. O investimento libidinal, de certa forma, é no próprio corpo também.

Simmel $(1927,1947)$ comenta que nas toxicomanias, todos os objetos são substituídos por um único, há uma fixação nele. Como esse objeto é introjetado no corpo, todo o investimento que seria destinado a outros objetos é voltado para o próprio corpo, inclusive as pulsões destrutivas.

Wulff (1932) aponta a necessidade de incorporação do objeto como uma substituição da relação genital. É uma espécie de introjeção erótica. Essa noção de desgenitalização e substituição da relação sexual pela relação com o objeto droga, inclusive, é apontada também por Abraham, Radó e Simmel. Os autores apontam nas toxicomanias o caráter regressivo das pulsões libidinais até a organização pré-genital, ou seja, auto-erótica.

Já os trabalhos produzidos a partir da teoria das relações de objeto têm como objetivo interrogar a natureza da relação de dependência do sujeito com o objeto droga. Essa investigação está pautada nas relações objetais primitivas e não na primazia da pulsão, como nos estudos com base freudiana clássica.

Glover (1928, 1932), inspirado em Klein, utiliza as relações de objetos pré-edipianas e os mecanismos de introjeção e projeção para pensar as toxicomanias. Para ele, a escolha de um objeto parcial nocivo para introjetar no 
corpo pode ter caráter sádico ou pode ser utilizado para atacar um objeto interno ruim. Rosenfeld também comenta que a droga pode ocupar um lugar de objeto mau e ser incorporada, e comenta da substituição de todos os objetos pela droga.

Winnicott (1951) também comenta o caráter regressivo existente nas toxicomanias, mas dá enfoque às relações primitivas e simbolização das figuras parentais. Para ele, quando o objeto de amor não é simbolizado e há uma falha nos fenômenos transicionais, o objeto parcial utilizado para esse fim é patológico. A toxicomania é definida como uma patologia dos objetos transicionais. A concepção de Joyce McDougall (1982) é similar a essa à medida em que ela confere às drogas o estatuto de objeto adictivo tranquilizador. Ela aponta que, em um distúrbio na relação eu-objeto, não há uma representação interna de uma instância materna tranquilizadora. O recurso a esse objeto adictivo é, portanto, frequente.

Baseado nas contribuições de Winnicott e McDougall sobre os fenômenos e objetos transicionais, Sedeu (2014) comenta que num processo "saudável", os objetos transicionais vão sendo desinvestidos à medida em que a criança amplia seu âmbito de interesses. Caso contrário, ocorre uma espécie de psicopatologia nos fenômenos transicionais. Por não possuir uma representação interna que o tranquilize diante de situações de tensão, objetos externos são utilizados para auxiliar nessa função que não se realiza sozinha pelo sujeito, então esses objetos tornam-se adictivos. Sedeu sugere um modelo geral para pensar a toxicomania a partir de um enforque relacional:

A falta de um objeto interno bom e forte leva a uma fragilidade do ego do indivíduo, que o torna incapaz de lidar com as frustrações e ansiedades, fazendo com que as tensões psíquicas (originadas do ambiente ou do mundo interno) sejam sentidas como insuportáveis. O indivíduo, então, busca utilizar drogas (objetos externos) cujo efeito farmacotóxico possibilite um alívio (temporário) dessas tensões, dissipando os sentimentos que dão origem às tensões psíquicas. A impossibilidade de um objeto externo suprir consistentemente uma falha no mundo interno leva ao uso compulsivo da droga pelo adicto. (Sedeu, 2014, p.118)

Segundo o autor, a origem dessa falha no objeto interno está na relação infantil mãe-bebê e pode se dar pela ausência ou presença excessiva desta. Na ausência, o objeto interno perde seu sentido e passa a ser persecutório. Diante dessa ameaça, os objetos transicionais são utilizados de forma constante para evitar o mal-estar. Na presença constante, a criança não possui a capacidade de estar só, demandando sempre a presença da mãe diante de dificuldades. Posteriormente os objetos serão utilizados com essa mesma função de "cuidar e acalmar" diante de situações ameaçadoras. (Sedeu, 2014) 
De acordo com Zimerman (2008), os drogadictos sofrem da "patologia do vazio", ou seja, por conta de sua primitiva angústia de desamparo, tentam preencher um vazio existencial através de drogas e de outros objetos. Por se tratar de uma forma de sentir-se vivo, a abstinência traria um grande sentimento de vazio e de não-existência. De acordo com o referido autor, tratase de uma estruturação psíquica idealizadora, o que é um fator que dificulta o tratamento. Zimerman (2008) ainda aproxima as drogadições à perversão, considerando a droga como fetiche.

Gurfinkel (2007) também encontrou semelhanças entre as adicções e o fetichismo à medida em que começou a estudar o tema a partir da teoria pulsional freudiana e se debruçou sobre o conceito de perversão da pulsão.

Podemos arriscar a hipótese que a adicção é um fetichismo em sua forma mais pura, destituído de sentido simbólico, como se qualquer conexão significante tivesse sido desligada. Sobreviveu apenas o ato e a repetição compulsiva que o anima; sobrou o ato sem sentido dramático, sem cenário nem enredo (p.18).

Essa hipótese está pautada na noção de que, no fetichismo, há uma fixação em um objeto e uma operação inconsciente de deslocamento do objetofetiche com a finalidade de negar um aspecto intolerável da realidade da castração. Além disso, a operação de negação presente no fetichismo resulta numa divisão do eu à medida em que, na operação, o objeto é apagado e depois aparece, e a realidade é negada e depois reconhecida. Quanto a isso, a negação da realidade já é notadamente reconhecida na toxicomania devido aos efeitos produzidos durante o uso.

Silveira (2013) destaca que o toxicômano tem dificuldades de lidar com frustrações e inscrever-se na castração, tendo um desbordamento pulsional e dificuldade de mediação simbólica em relação à falta e seus objetos, o que aproxima a clínica dos toxicômanos à dos adolescentes.

É elementar mencionar que, neste trabalho, priorizamos discutir a função que o objeto possui na constituição do sujeito e a relação que o sujeito estabelece com o objeto droga, bem como as consequências para o funcionamento psíquico deste. A relação da falta de objeto aparece como fundamental e constituinte na teoria psicanalítica. Assim, o conceito de objeto apresentado por Freud (1905/1996) em seus "Três ensaios sobre a teoria da sexualidade", já esboça que a busca por objetos remete à tendência a reencontrar um objeto perdido (Lacan, 1956-1957/1995).

Em seu seminário, "As relações de objeto", Lacan (1956-1957/1995) aborda essas relações partindo não do objeto, mas da falta deste. Uma falta que, de acordo com o autor, seria a "mola da relação do sujeito com o mundo" 
(p. 35), que se estabelece sob três aspectos, a saber, na dívida simbólica, no dano imaginário e no furo no real.

No que diz respeito a dívida simbólica, esta é referida à submissão à castração, que se constitui como uma dívida a algo que sanciona a lei, que conta tanto como suporte quanto como punição, daí o objeto é sempre imaginário. Vale dizer que o objeto da castração é o falo, nessa circunstância, falo imaginário. Na perspectiva da frustração, por sua vez, trata-se de um objeto real, por mais que a frustração implique um dano imaginário. O objeto de privação é simbólico a contornar um furo, já que é uma falta real o que está em questão.

No momento pré-edipiano, no qual a criança e a mãe encontram-se em uma relação de pretensa dualidade, a mãe é objeto de amor e objeto simbólico para a criança. Esta, por sua vez, se coloca como falo, se oferecendo, numa relação imaginária, a satisfação daquilo que falta à mãe. "É na relação com a mãe que a criança experimenta o falo como o centro do desejo dela" (Lacan, 1956-1957/1995, p. 230).

A mãe, em seu movimento de presença-ausência, constitui o primeiro agente da frustração articulada à criança, que numa ordem imaginária, tratase de um objeto real, o seio.

Green (1984/1986, p. 54-55) entende que o "objeto, no seu duplo estatuto de interno e externo, desempenha um papel constitutivo deste funcionamento" e que este é "revelador das pulsões" (ibidem, p.58) no sentido de ser não um criador destas, mas uma condição de sua existência.

\section{5}

\section{Considerações Sobre a Estrutura, o Quadro, o Sintoma}

Conforme apresentado no capítulo anterior, os autores pós-freudianos divergiram bastante em suas classificações das toxicomanias, e o estatuto psicopatológico também variou. Abraham (1908) faz uma comparação do alcoolismo com o sintoma neurótico quando aponta a expressão da sexualidade e a resistência existente em ambos. O autor também traça um paralelo entre as intoxicações e o que chama de sintoma da compulsão alimentar. Quando tenta fazer uma distinção entre um hábito e uma compulsão patológica, Abraham comenta que a intolerância à frustração diante da privação dessa fonte de prazer seria um indicativo, pois essa reação gera uma marca patológica que leva à formação de sintomas. O sintoma aqui aparece como uma consequência dessa intolerância à frustração, mas a causa da fixação a um objeto não é esclarecida.

Ferenczi (1911) também utiliza o termo sintoma ao referir-se ao alco- 
olismo. Knight (1937) classifica o alcoolismo como um sintoma, um recurso para lidar com os conflitos emocionais. Fenichel (1945), que trabalhou o vício com e sem drogas, também seguiu a mesma linha. Bergeret (1982), apesar de reconhecer algumas características em comum aos "dependentes", afirma que não existe uma estrutura ou personalidade toxicômana. Qualquer estrutura ou personalidade estaria suscetível ao vício. Glover $(1928,1932)$ classifica as toxicomanias como estados transicionais, que estão entre a neurose e a psicose.

Dentre os autores contemporâneos, essa divergência também existe. Serretti (2012) aponta o caráter estruturante da toxicomania e a define como um quadro patológico não-restrito a uma classificação fixa. As toxicomanias se diferem nos conflitos psíquicos aos quais estão ligadas, mas tem em comum o fato de representarem, de alguma forma, uma medicação para lidar com a angústia. A autora afirma ainda que o ato toxicomaníaco aparece como uma formação sintomática, mas não é sintoma por não se tratar de uma formação inconsciente.

Santos e Costa-Rosa (2007) falam das toxicomanias como um gozo do Outro - que não passa pela linguagem e não tem uma falta simbolizada - e que, portanto, as drogas seriam substitutas do gozo mítico total que foi privado no momento no qual o sujeito foi inserido no mundo de linguagem. O gozo das toxicomanias teria características do gozo do Outro, onde há um curto-circuito no simbólico e a droga, que proporciona um gozo direto no corpo, pode ser vista enquanto substituta ao sintoma.

Sob uma ótima lacaniana, Andrade (2001) ressalta que o toxicômano é uma figura do gozo. A toxicomania, contudo, pode ser tomada como sintoma num sentido mais amplo, porém não num sentido mais estrito, pois trata-se de evitar a castração pela ruptura com o Outro e de uma "cristalização da elaboração fantasística" (p. 66). O que está colocado aqui é que não se trata de uma formação inconsciente, pois a droga aparece como solução quando o sintoma não basta. Ela é colocada como objeto causa de gozo e não como objeto causa de desejo.

Devido às suas particularidades, a toxicomania não é considerada por Andrade (2001) uma estrutura, mas uma operação sobre as estruturas. Ela rompe com o gozo fálico porque o gozo é auto-erótico, é no próprio corpo, então não se trata do gozo do neurótico. Ela desmente o outro sexo, mas não é perversão porque o gozo da droga não passa pela fantasia. Na toxicomania há uma falha na metáfora paterna, mas não há foraclusão e exclusão do Outro. Não se trata mais da predominância da teoria do significante ou da existência ou não da metáfora paterna. Há aqui uma descontinuidade e flexibilização de fronteiras. Nesse panorama, Andrade (2001) aproxima a toxicomania da 
segunda clínica lacaniana, a clínica do Real, da qual não nos ocuparemos nesse trabalho.

Vemos que há uma grande discussão sobre a estrutura psíquica a qual o sujeito toxicômano está inserido, mas há também a noção de que não se trata de uma estrutura psíquica exclusiva, mas sim da relação singular de cada sujeito com objeto droga independente de sua estrutura. A repetição é inerente à condição do sujeito castrado, mas no caso dos "não-castrados", a droga marcaria uma relação com o sintoma. No sujeito psicótico a droga exerce uma suplência moderadora do gozo do Outro, serve de suplência para o que não é simbolizado. (Gianesi, 2005)

Junqueira e Coelho Júnior (2008) que nos advertem que as adicções, assim como outras manifestações, tais como distúrbios alimentares e doenças psicossomáticas não devem ser reduzidas às estruturas clássicas. A escola inglesa as definem como borderline, a partir de uma noção de borderline enquanto quadro clínico com estrutura própria e forma singular de tratamento. A escola francesa utiliza o termo "estados-limite" ou "casos-limite", diferenciando-se da escola inglesa quanto ao caráter estrutural e apostando em um modelo transitório (Figueiredo, 2000). Alguns lacanianos utilizam o termo "pacientes inclassificáveis" por não considerá-los neuróticos, perversos ou psicóticos. O termo "patologias atuais", como propõe Mayer (2001) também é utilizado nesse contexto para definir casos atuais e patologias do ato ou acting out.

Pudemos perceber que as concepções expostas até aqui se mostraram diversas em suas classificações, aproximações e bases teóricas. Não é nossa intenção, aqui, definir o estatuto psicopatológico das toxicomanias ou uma estrutura específica, mas apresentar as dificuldades encontradas nessa tarefa e quais são algumas das diversas teorias feitas nesse sentido.

Uma parte dos autores aposta em um caráter estrutural e outra parte aposta em um quadro psicopatológico. Alberti, Inem \& Rangel (2003) afirmam:

Muitas são as contribuições da psicanálise no campo das toxicomanias. Tal diversidade se produz a partir da variedade de abordagens teóricas e clínicas possíveis no trato da questão, devido à multiplicidade de leituras da teoria psicanalítica. A complexidade do tema ganha ainda maior força em razão da já aludida interdisciplinaridade devido à "urgência social e política que a questão das drogas colocou no espaço social (p.14).

Os autores afirmam, ainda, que as formas de lidar com o prazer e o desprazer e as relações estabelecidas com as drogas serão sempre singulares, e que o fenômeno em si não basta para determinar a estrutura do sujeito. A identificação se dará através da relação de cada um com a castração e como suas subjetividades são construídas, "estejam elas ligadas ou não ao consumo de drogas" (Alberti, Inem e Rangel, 2003, p. 16). 
Sobre isso, Serretti (2012) comenta:

Ressaltamos a importância de não considerar a toxicomania apenas como uma doença, mas sim interrogar-nos sobre o que busca ser restituído nesta formação sintomática. Os atos toxicomaníacos em geral não são formações do inconsciente, não estão estruturados como um sintoma, no sentido de algo que condensa muitos sentidos. A economia energética do aparelho psíquico na intoxicação crônica passa a ser regida por uma estratégia que impede o dispêndio pulsional em manter as formações de compromisso e sem elaborar outras saídas de conciliação diante do estranho material que vem à tona. $\mathrm{O}$ toxicômano consegue evitar os infortúnios do retorno do recalcado quando os recusa, valendo-se da intervenção química em seu corpo (p. 55).

Apesar de algumas variações e divergências entre vários autores citados aqui, podemos observar que há, em seus trabalhos, um enfoque específico em uma determinada característica da toxicomania ou em determinado conceito que os ajudaram a criar suas teorias. Foi possível observar, no entanto, que existem muitas características em comum também. Parece consenso geral que o uso enquanto objeto parcial na lógica do princípio do prazer se difere da toxicomania, onde já é possível observar um aspecto patológico no uso. Não necessariamente estamos falando de um estatuto psicopatológico, mas da relação adoecida com o objeto ao qual o toxicômano está submetido. O uso abusivo, de caráter repetitivo e compulsivo, impele o sujeito ao uso e à dependência desta, o que acarreta em consequências psíquicas, físicas e sociais para esse sujeito.

O uso compulsivo é apontado como uma busca de satisfação plena e tentativa de reencontro com o objeto perdido, o que não é possível, dado o caráter faltante da constituição do sujeito. Os aspectos narcísico e auto-erótico também são considerados por alguns autores ao tratarem o uso como uma tentativa de incorporação do objeto e uma tentativa de prazer auto-erótico (prazer corporal).

A relação alienante é apontada também como uma tentativa de constituição de uma imagem inteira do eu, operação que ocorre no estádio do espelho, como já foi citado. É importante ressaltarmos que a relação do imaginário se dá pelo simbólico e os dois registros se articulam. A relação imaginária (dual) precisa dessa intervenção de outra instância senão pode ser mortífera, como nos é visto com certa frequência no caso das toxicomanias.

Podemos supor que o toxicômano, sob o olhar de aspectos da teoria psicanalítica, nos mostra com sua insistência ao uso de substâncias tóxicas, pelo apelo a um objeto, sua busca por vivenciar experiências de prazer, justamente uma compulsão, uma repetição que visa prazer imediato. 
Apesar das variações teóricas, o fator mais comum dentre as proposições encontradas foi o do uso das substâncias como um remédio para a angústia de qualquer natureza, mesmo que essa medicação traga consigo dor de sofrimento. 


\section{5}

\section{Considerações Finais}

O campo das adicções é bem vasto em relação aos seus tipos e abordagens. A Medicina, Psicologia e Psicanálise, por exemplo, se ocupam de seus diferentes objetos em suas variáveis teorias e distintos tratamentos. Nos ocupamos, no entanto, da toxicomania, também denominada drogadição, dependência química, vício em drogas, uso abusivo de substâncias químicas, dentre outros termos utilizados para definir esse fenômeno. Interrogamos, a partir da teoria psicanalítica, o que a passagem do uso recreativo para o uso abusivo diz desse sujeito. A literatura psicanalítica nos apresenta algumas leituras a respeito das toxicomanias que trazem vieses distintos.

Esse trabalho teve como objetivo investigar as principais concepções teóricas acerca das toxicomanias na psicanálise e analisar de que forma essas teorias foram construídas, em quais conceitos e ideias elas foram baseadas e de que forma elas foram sendo modificadas à medida que novas perspectivas e novos conceitos surgiram, bem como observar de que forma essas teorias foram influenciadas pelas questões sociais que se apresentavam à época.

Nenhuma teoria ou ideia surge sem que haja um contexto social que a influencie ou outras teorias já estabelecidas para que sirvam de modelo, mesmo que seja um modelo que venha a ser questionado. O fato é que a quando a psicanálise surgiu e as toxicomanias passaram a ser um grande problema (a partir do século XIX), o uso de tóxicos já era presente em diversas civilizações e culturas há séculos. A relação que o homem estabeleceu com essas substâncias ultrapassa o caráter recreativo ou destrutivo, mais conhecidos e comentados na atualidade. O limite entre o que era considerado alimento, remédio, objeto sagrado ou demoníaco era fluido e dependia do sentido dado a essa droga de acordo com cada cultura e cada época.

Observamos que a relação do uso de drogas com rituais religiosos é muito próxima, e o método de incorporação desse objeto considerado sagrado se faz presente em religiões cristãs, indígenas e de matriz africana. Apesar da presença das drogas nesses rituais, o uso de substâncias "não-sagradas" para fins medicinais ou recreativos foi perseguido por muitas religiões, que consideravam essas práticas como "feitiçaria".

O uso de droga para fins medicinais sempre existiu, como pudemos 
observar no uso de chás, láudanos, garrafadas etc ao longo da história. A alquimia deu lugar à farmacologia, e seu fortalecimento, juntamente com o surgimento das faculdades de medicina, modificou a forma como essas substâncias eram vistas e utilizadas, e agora as drogas eram receitadas ou rechaçadas de acordo com o discurso médico, que as classificou de acordo com seu potencial terapêutico e grau de nocividade.

Vimos como as questões políticas e econômicas influenciaram para a liberação ou proibição do uso e comércio de drogas e como houve uma mudança na visão do consumo, que antes era visto através de uma ótica moral e criminal e, com o advento da medicina e da psiquiatria, passou a ser visto como uma doença. Nesse sentido, se antes os usuários eram apenas considerados moralmente defeituosos e eram presos, depois passaram a ser considerados doentes que precisam ser tratados. Essa forma de tratamento também foi sendo modificada a partir da evolução do entendimento do fenômeno e dos variados aspectos envolvidos nele. Esses "doentes" que eram internados compulsoriamente passaram a receber uma nova forma de tratamento, que não os prendia nem os infantilizava.

Essa mudança de paradigma é observada na transformação das políticas públicas brasileiras voltadas para essa população. O modelo de tratamento asilar deu lugar à uma rede de tratamento extra-hospitalar, fruto das exigências de desinstitucionalização da reforma psiquiátrica. As novas políticas de atenção e tratamento adotam um modelo comunitário e passam a oferecer um tratamento multiprofissional integrado em vários âmbitos, desde a atenção primária até dispositivos como os centros de atenção psicossocial (CAPS), núcleos de atenção psicossocial (NAPS) e vários outros. Essa mudança de modelo foca em ações de tratamento, prevenção e redução de danos, bem como a desestigmatização do usuário como doente ou perigoso que, como vimos, foi uma visão construída ao longo de muitos anos.

Com esse retorno à história do uso de drogas foi possível observar como o consumo, a proibição e as propostas de tratamento foram diretamente influenciadas pelas noções vigentes na época. Antes do discurso médico vigorar, a visão e o tratamento eram pautados nos aspectos morais e sociais. A partir do surgimento da farmacologia e da psiquiatria, o foco foi voltado para as substâncias nocivas presentes nas drogas, e o aspecto orgânico liderou as teorias e propostas de tratamento.

Nesse sentido, partimos para a investigação das teorias sobre esse tema dentro da psicanálise, buscando compreender o contexto no qual foram formuladas. Ressaltamos que a cocaína foi, em determinado momento, um remédio muito utilizado e receitado pelos médicos como anestésico e tratamento para 
diversas afecções. Foi nesse contexto que Freud começou seus estudos sobre o uso dessa substância, nos quais comenta sobre o potencial terapêutico da droga. Ele também aponta a possibilidade de usar a cocaína como substância estimulante no tratamento da melancolia.

A produção teórica de Freud acerca das toxicomanias não é muito vasta, mas encontramos em nossa pesquisa algumas menções ao vício e ao recurso às substâncias tóxicas. A perspectiva apresentada por ele em relação aos vícios é que todos os vícios são substitutos da masturbação, o vício primário. Quando comenta sobre a relação do bebedor com o vinho, o autor também o faz a partir da noção de objeto parcial que gera prazer e serve como um substituto ao objeto original.

Como vimos, Freud comenta em alguns momentos de sua obra sobre a relação do uso de drogas e as exigências da cultura que impedem a satisfação das pulsões sexuais e gera sofrimento. Essa perspectiva é apresentada em 1912 e posteriormente em 1930. As drogas, aliás, são consideradas por ele como um dos paliativos indispensáveis para enfrentar o sofrimento da vida. A produção de Freud sobre o tema foca em um tipo de modalidade de uso que está dentro da lógica do princípio do prazer, na qual os objetos parciais são reclamados pelas pulsões parciais numa tentativa de tamponar, de alguma forma, uma falta constituinte do sujeito. No entanto, nas toxicomanias, o que está colocado é um "para além" do princípio do prazer, no qual há uma relação de dependência com as substâncias no sentido de uma repetição penosa e destrutiva imposta ao sujeito no que diz respeito ao uso e à falta da droga.

Os autores alunos de Freud seguem uma linha pulsional e desenvolvem suas teorias a partir da perspectiva da satisfação sexual, focando no uso de substâncias como uma substituição à masturbação, desgenitalização e regressão às fases pré-genitais, sobretudo a oral. Também foi apontado por muitos autores o caráter infantil existente nos sujeitos toxicômanos, pois não toleram a frustração e precisam ser satisfeitos imediatamente. A suspensão das defesas sob o efeito dos tóxicos se mostra muito presente em várias teorias. Algumas, inclusive, apontam que o uso suspende a ação severa do superego, enquanto teorias posteriores já apontam o papel do superego como instância que ordena o imperativo do gozo.

Alguns pós-freudianos também relacionam o recurso aos tóxicos à melancolia e ao ciclo maníaco-depressivo, no sentido de a droga funcionar como um estimulante que gera uma mania artificial durante o uso e leva o sujeito a um estado depressivo durante a falta da droga. Pós-freudianos também apontaram as questões narcísicas existentes nas toxicomanias, relacionando-as com distúrbios narcísicos ou neuroses narcísicas. O caráter auto-destrutivo e a perversão 
aparecem nessas obras, mas não são tão aprofundadas pelos autores.

Encontramos algumas tendências em relação às teorias, que podem ser classificadas nos seguintes eixos:

1. teorias que focam nos aspectos narcísicos envolvidos no processo de intoxicação e na modalidade de prazer auto-erótico, que é visto por alguns autores como um movimento de regressão libidinal que acarreta na satisfação desgenitalizada;

2. teorias que focam no aspecto da identificação e alienação, como as que ilustram o estádio do espelho como período de identificação (e, no qual, haveria alguma falha nesse processo) ou as teorias que aproximam a melancolia à identificação do sujeito com a droga;

3. teorias que focam no caráter auto-destrutivo existente nas toxicomanias, atribuindo ao ato ação das pulsões de morte e/ou masoquismo;

4. teorias que atribuem à compulsão à repetição a tentativa de reestabelecer uma vivência alucinatória e reencontrar o objeto perdido, que é mítico;

5. teorias que focam na dependência a partir das relações objetais primitivas e dos mecanismos de introjeção e projeção.

Em relação ao estatuto psicopatológico, encontramos as seguintes classificações: sintoma; quadro psicopatológico; estado transicional; operação sobre as estruturas; patologias atuais; borderlines; pacientes inclassificáveis, dentre outros. A maioria dos autores consultados defende que não há uma estrutura específica nas toxicomanias, mas sujeitos de diversas estruturas poderiam ser acometidos, pois a relação singular que cada sujeito estabelece com esse objeto independe de estrutura.

Neste trabalho optamos por não fazer uma distinção entre as drogas, apesar de admitirmos a existência de diferentes substâncias com efeitos muito distintos e que comprometem o organismo de formas diversas também. Nos limitamos a dissertar sobre "tóxicos" em geral, pois não encontramos na literatura levantada uma distinção significativa em relação à diferença das substâncias no que diz respeito à teoria psicanalítica e demais obras que abordam as toxicomanias. O foco da maioria dos autores (e o nosso) foi na relação estabelecida entre o sujeito e esse objeto tóxico, seja ele qual for.

Ressaltamos que desde o princípio as investigações psicanalíticas se pautaram no recurso aos tóxicos e na relação estabelecidas com ele, ao invés de abordarem o tema a partir das substâncias, como algumas teorias médicas o fazem. A partir do levantamento teórico feito, fica evidente a transição do 
modelo pulsional, que predominava entre os alunos de Freud, para um modelo relacional que já levava em consideração as relações objetais, com enfoque nas relações parentais primitivas. A partir do conceito de gozo lacaniano e das teorias do discurso desenvolvidas por ele, vários autores passaram a trabalhar o uso dos tóxicos a partir desse enfoque, que já envolve questões sociais e econômicas.

Apesar de algumas divergências no enfoque teórico, a questão do recurso aos tóxicos como um mecanismo de defesa se destacou, embora observemos uma grande quantidade de trabalhos que partem do pressuposto da autodestruição e focam nos conceitos de pulsão de morte e masoquismo. O que se mostrou claro, para nós, é que mesmo que o uso seja nocivo e mortífero, ele se dá a partir de uma tentativa de sanar uma angústia, seja ela proveniente do ambiente externo ou de questões internas. É um remédio que, dependendo da proporção, se torna um veneno.

A principal contribuição deste trabalho se dá no sentido de ter feito um retorno às origens das teorias psicanalíticas acerca das toxicomanias, levando em consideração o contexto no qual estas surgiram e de que forma foram sendo modificadas ao longo do desenvolvimento da psicanálise. A análise das teorias a partir dos conceitos clássicos e a exposição das principais teorias existentes sobre o tema também se mostram importantes subsídios para a classificação destas elaborações em relação às perspectivas nas quais elas estão inseridas. Por ser um tema complexo que afeta os indivíduos num âmbito individual e social, é fundamental que a teoria psicanalítica seja estudada a partir de suas variações para que possa embasar a prática clínica, que requer a compreensão das particularidades desses casos e parece demandar um modelo diferente de técnica e/ou manejo.

Este trabalho possui algumas limitações, dentre elas, a impossibilidade de aprofundarmos mais todos os conceitos abordados nessa produção devido a quantidade de material levantado em nossa pesquisa. Além disso, alguns conceitos e autores ficaram de fora do trabalho, o que restringe um pouco a nossa análise. Não adentramos no campo das perversões e psicoses, e também não abordamos a relação das toxicomanias com o fetiche, os tipos de gozo, a relação com a denominação borderline, o uso de drogas como acting out e também não aprofundamos na nossa discussão a questão do uso de tóxicos enquanto um sintoma social. Mais uma limitação do nosso trabalho é a falta de discussão sobre as possíveis implicações práticas dessas teorias apresentadas, uma vez que possuem algumas divergências em relação ao estatuto psicopatológico e à etiologia dos casos.

Este trabalho abre caminho para produções futuras que podem partir 
das análises aqui apresentadas e expandir os conceitos e autores, enriquecendo assim a análise do tema dentro da psicanálise. Futuros trabalhos também poderão discutir as implicações clínicas dessas teorias, de modo a especificar as possíveis divergências e convergências em relação às orientações no que diz respeito ao manejo e técnicas mais profícuas no tratamento psicanalítico desses casos. 


\section{Referências bibliográficas}

Abraham, K. (1908). The Psychological Relations Between Sexuality and Alcoholism. In K, Abraham. Selected Papers on Psychoanalysis. (pp. 80-89). Londres: Karnac books, 1988.

Abraham, K. (1910). Hysterical Dream-States. In K. Abraham. Selected Papers on Psychoanalysis. (pp.90-124). Londres: Karnac books, 1988.

Abraham, K. (1916). The First Pregenital Stage of the Libido. In K. Abraham. Selected Papers on Psychoanalysis. (pp. 248-279). Londres: Karnac books, 1988.

Abraham, K. (1924). A Short Study of the Development of the Libido, viewed in the light of mental disorders. In K. Abraham. Selected Papers on Psychoanalysis. (pp.418-501). Londres: Karnac books, 1988.

Alberti, S., Inem, C. L., \& Rangel, F. C. (2003). Fenômeno, estrutura, sintoma e clínica: a droga. Revista Latinoamericana de Psicopatologia Fundamental, 6(3), (pp. 11-29). Recuperado de https://doi.org/10.1590/141547142003003002

Almeida de, A. R. B. (2010). Toxicomanias: uma abordagem psicanalítica. Salvador: EDUFBA.

American Psychiatric Association (2008). Manual diagnóstico e estatístico de transtornos mentais DSM-5. In M. Nascimento et al (trad). 5 ed. Porto Alegre: Artmed, 2014. Recuperado a partir de http://www.tdahmente.com/wpcontent/uploads/2018/08/Manual-Diagn\%C3\%B3stico-e-

Estat\%C3\%ADstico-de-Transtornos-Mentais-DSM-5.pdf.

Andrade de, L. F. F. (2001). A clínica cem anos depois: novas figuras de gozo. Cogito, 3, 61 .

Araújo, A. C. \& Lotufo Neto, F. (2014). A nova classificação Americana para os Transtornos Mentais: o DSM-5. Revista Brasileira de Terapia Comportamental e Cognitiva, 16(1), pp. 67-82. Recuperado a partir de http://pepsic.bvsalud.org/scielo.php?script=sci_arttext\&pid=S151755452014000100007\&lng=pt\&tlng=pt.

Arteiro, I. L., \& Freire De Queiroz, E. (2011). O Corpo na Toxicomania: Uma Primazia da Sensação? Revista Mal Estar e Subjetividade, 11(4), 1575-1596. Recuperado de http://pepsic.bvsalud.org/scielo.php?script=sci_arttext\&pid=S151861482011000400011

Ávila, M. T. (2010). A perspectiva da psicanálise no futuro das toxicomanias. Recuperado https://twiki.ufba.br/twiki/pub/CetadObserva/Psicanalise/A_perspectiva_da_p sican\%E1 lise_no_futuro_das_toxicomanias.pdf 
Bento, V. E. S. (2010). Introdução às justificativas clínicas e teóricas da hipótese das paixões "tóxicas". Estudos de Psicologia (Campinas), 27(1), (pp. 109120). Recuperado de https://doi.org/10.1590/S0103-166X2010000100013

Brasil. (1998). Decreto $n^{\circ}$ 2.632. Dispõe sobre o Sistema Nacional Antidrogas, e dá outras providências. Lex: Diário Oficial da União. Brasília.

Brasil. (2003). A política do Ministério da Saúde para a Atenção Integral aos Usuários de Alcool e outras Drogas. Brasília: Secretaria de Atenção à Saúde.

Brasil. (2004). Saúde Mental no SUS: Os centros de atenção psicossocial. Brasília: Secretaria de atenção à saúde.

Brasil. (2005). Reforma psiquiátrica e política de saúde mental no Brasil. In: Coordenação Geral de Saúde mental. Conferência regional de reforma dos serviços de saúde mental. Brasília: Secretaria de atenção à saúde.

Brasil. (2008). Clínica Ampliada, Equipe de Referência e Projeto Terapêutico Singular. 2 ed., Brasília: Secretaria de Atenção à Saúde.

Brasil. (2010a). Legislação e Políticas Públicas sobre drogas no Brasil. Brasília: Secretaria Nacional de Políticas sobre drogas, 2010.

Brasil. (2010b). Decreto $n^{\circ}$ 7.179. Institui o plano integrado de enfrentamento ao crack e outras drogas, cria seu comitê gestor e dá outras providências. Lex: Diário Oficial da União. Brasília, p. 43. Maio/Jul. 2010.

Brasil. (2011). Portaria $n^{\circ}$ 3088. Institui a Rede de Atenção Psicossocial para pessoas com o sofrimento ou transtorno mental e com necessidades decorrentes do uso de crack, álcool e outras drogas, no âmbito do Sistema Único de Saúde (SUS). Lex: Diário Oficial da União. Brasília, pp. 50-60.

Brasil. (2014). O uso de substâncias psicoativas no Brasil: módulo 1. 5 ed, Brasília: Secretaria Nacional de Politicas sobre Drogas.

Brasil. (2017). A história e os contextos socioculturais do uso de drogas. Brasília: Secretaria Nacional de políticas sobre drogas. Recuperado de http://aberta.senad.gov.br/medias/original/201705/20170509-102625-001.pdf

Caravelli, S. A. L. (2005). Inundação no deserto: A toxicomania pelo viés da melancolia (dissertação de mestrado). Universidade Federal do Rio de Janeiro, Programa de Pós-graduação em Teoria Psicanalítica, Rio de Janeiro.

Carneiro, H. (2005). Transformações do significado da palavra "droga": das especiarias coloniais ao proibicionismo contemporâneo. In R.P. Venâncio \& H. Carneiro (orgs.), Álcool e drogas na história do Brasil. (pp. 11-27). Belo Horizonte: Editora Pucminas.

Conte, M. (2001). O luto do objeto nas toxicomanias. Textos, (pp. 91-107). Porto Alegre: APPOA. 
Dias, T. A., \& Correia, F. G. (2015). Toxicomania e sociedade contemporânea: articulações. Revista Uningá, 24(1), (pp. 90-97).

Escohotado, A. (1996). A brief history of drugs: from the stone age to the stoned age. (Kenneth A. Symington, Trad.). Rochester: Vermont, 1999.

Ferenczi, S. (1911a) O papel da homossexualidade na patogenia da paranoia. In S. Ferenczi. Obras Completas (v. 1. pp. 155-171). São Paulo: Martins Fontes, 1991.

Ferenczi, S. (1911b) O álcool e as neuroses. In S. Ferenczi. Obras Completas (v. 1. pp. 173-177). São Paulo: Martins Fontes, 1991.

Figueiredo, B. G. (2005). O arranjo das drogas nas boticas e farmácias mineiras entre os séculos XVIII e XIX. In R.P. Venâncio \& H. Carneiro (orgs.), Álcool e drogas na história do Brasil. (pp. 141-154). Belo Horizonte: Editora Pucminas.

Figueiredo, Luís Claudio. (2000). O caso-limitee as sabotagens do prazer. Revista Latinoamericana de Psicopatologia Fundamental, 3(2), 61-87. https://doi.org/10.1590/1415-47142000002005

Fiore, M. (2005). A medicalização da questão do uso de drogas no brasil: reflexões acerca de debates institucionais e jurídicos. In Venâncio, R. P \& Carneiro, H. (orgs), Álcool e drogas na história do Brasil (pp. 257-290). Belo Horizonte: Editora Pucminas.

Foucault, M. (1972). História da Loucura na Idade Clássica. São Paulo: Perspectiva, 1978.

Freud, S. (1897a). Sinopses dos escritos científicos do Dr. Sigm. Freud 1877-1897. In S. Freud. Primeiras publicações psicanalíticas (1893-1899). (v. 3). Rio de Janeiro: Imago, 1996.

Freud, S. (1897b). Carta 79. In S. Freud. Edição Standard Brasileira das Obras Psicológicas Completas de Sigmund Freud (v. I). Rio de Janeiro: Imago, 1996.

Freud, S. (1898). A sexualidade ne etiologia das neuroses. In S. Freud. Primeiras publicações psicanalíticas (1893-1899). (v. 3). Rio de Janeiro: Imago, 1996.

Freud, S. (1900). O método de interpretação dos sonhos: análise de um sonho modelo. In S. Freud. A interpretação dos sonhos (I). (v.4). Rio de Janeiro: Imago, 1996.

Freud, S. (1900-1901). A psicologia dos processos oníricos. In S, Freud. A interpretação dos sonhos (II) e sobre os sonhos: (pp. 541-645). Rio de Janeiro: Imago, 1996.

Freud, S. (1905). Três ensaios sobre a teoria da sexualidade. In S. Freud. Um caso de histeria, três ensaios sobre a sexualidade e outros trabalhos (1901-1905). (pp.119-217). Rio de Janeiro: Imago, 1996. 
Freud, S. (1905). O Mecanismo de prazer e a psicogênese do chiste. In S. Freud. Obras completas, volume 7: O chiste e sua relação com o inconsciente. São Paulo: Companhia das Letras, 2017.

Freud, S. (1911). Formulações sobre os dois princípios do acontecer. In S. Freud. Escritos sobre a psicologia do inconsciente (1911-1915), (pp. 63-70). Rio de Janeiro: Imago, 2004.

Freud, S. (1912). Sobre a mais comum depreciação na vida amorosa (contribuições à psicologia do amor II). In S. Freud. Obras completas, volume 9. São Paulo: Companhia das letras, 2017.

Freud, S. (1914). À guisa de introdução ao narcisismo. In S. Freud. Escritos sobre a psicologia do inconsciente (1911-1915). (pp. 95-119). Rio de Janeiro: Imago, 2004

Freud, S. (1915). Pulsões e destinos da pulsão. In S. Freud. Escritos sobre a psicologia do inconsciente (1911-1915), (pp. 133-173). Rio de Janeiro: Imago, 2004.

Freud, S. (1917). Luto e melancolia. In S. Freud. Obras completas, volume 12: Introdução ao narcisismo, ensaios de metapsicologia e outros textos (19141916). (pp. 127-144). São Paulo: Companhia das letras, 2010.

Freud, S. (1920). Além do princípio de prazer. In S. Freud. Além do princípio de prazer, psicologia de grupo e outros trabalhos (1920-1922). (pp.13-75). Rio de Janeiro: Imago, 1996.

Freud, S. (1920). Além do princípio de prazer. In S. Freud. Escritos sobre psicologia do inconsciente vol 2 (1915-1920). Rio de Janeiro: Imago, 2004.

Freud, S. (1924). O problema econômico do masoquismo. In S. Freud. Obras completas, volume 16: O eu e o id, "autobiografia" e outros textos (19231925). (pp. 184-202). São Paulo: Companhia das letras, 2011.

Freud, S. (1925). A negação. In S. Freud. Obras completas, volume 16: O eu e o id, “autobiografia" e outros textos (1923-1925). (pp. 275-282). São Paulo: Companhia das letras, 2011.

Freud, S. (1930). O Mal-estar na civilização. In S. Freud. Obras completas, volume 18. São Paulo: Companhia das letras, 2017.

Garcia-Roza, L. A. (2003). A Morte e pulsão de morte. In L. A. Garcia-Roza. Acaso e repetição em psicanálise: uma introdução à teoria das pulsões. (pp.72-80). Rio de Janeiro: Jorge Zahar ed.

Giacobone, R. V. (2012). O sujeito e as drogas: marcas identitárias e contemporaneidade (dissertação de mestrado). Pontifícia Universidade Católica do Rio Grande do Sul, Programa de pós-graduação em Psicologia, Porto Alegre. 
Gianesi, A. P. L. (2005). A toxicomania e o sujeito da psicanálise. Psychê, 9(15), (pp. 125-138).

Recuperado de http://pepsic.bvsalud.org/scielo.php?script=sci_arttext\&pid=S1415$11382005000100010 \& \operatorname{lng}=\mathrm{pt} \& \mathrm{nrm}=$ iso \&tlng $=\mathrm{pt}$

Green, A. (1984). Pulsão de morte, narcisismo negativo, função desobjetalizante. In D. Widlöcher (Org.). A pulsão de morte (pp. 53-64). São Paulo: Escuta, 1986.

Gross, A. (1935). The Psychic Effects of Toxic and Toxoid Substances. International Journal of Psychoanalysis, (v.14).

Gurfinkel, D. (2007). Adicções: da perversão da pulsão à patologia dos objetos transicionais. Psychê, 11 (20). (pp. 13-28). Recuperado de http://pepsic.bvsalud.org/scielo.php?pid=S1415$11382007000100002 \&$ script $=$ sci_arttext\&tlng=en

Gurfinkel, D. (2014). Adicções: paixão e vício. São Paulo: Casa do Psicólogo.

Hyppolite, J. (1954). Comentário falado sobre a "Verneinung" de Freud. In J. Lacan. Escritos. (pp. 893-902). Rio de Janeiro: Jorge Zahar Ed., 1998.

Junqueira, C., \& Coelho-Junior, N. (2008). Interpretação e Manejo do Enquadre na Clínica de Pacientes-Limite. (pp. 137-157). Tempo Psicanalitico, 40(1).

Labate, B. C \& Pacheco, G. (2005). As origens históricas do santo daime. In Venâncio, R. P \& Carneiro, H. (orgs), Álcool e drogas na história do Brasil (pp.231-255). Belo Horizonte: Editora Pucminas.

Lacan, Jacques. (1949). O estádio do espelho como formador da função do eu. In J. Lacan. Escritos. (pp. 96-103). Rio de Janeiro: Zahar, 1998.

Lacan, Jacques. (1956-1957). O seminário, livro 4: A Relação de objeto. Rio de Janeiro: Jorge Zahar, 1995.

Lacan, Jacques. (1957-1958). O Seminário, livro 5: As formações do inconsciente. Rio de Janeiro: Zahar, 1999.

Lacan, Jacques. (1964). O seminário, livro 11: Os quatro conceitos fundamentais da Psicanálise. Rio de Janeiro: Jorge Zahar, 2008.

Loose, R. (2002). The Subject of Addiction: Psychoanalysis and The Administration of Enjoyment. New York: Karnac.

Lopes, M. B. \& Lima, E. S. (2005). A falsificação de vinho na cidade de Ouro Preto no século XIX. In Venâncio, R. P \& Carneiro, H. (orgs), Álcool e drogas na história do Brasil (pp.203-216). Belo Horizonte: Editora Pucminas.

Macedo, M. M. K., \& Dockhorn, C. N. de B. F. (2014). Para além da substância : considerações sobre o sujeito na condição da toxicomania. Revista Psicologia: Teoria e Prática, 16(2), pp. 41-52. Recuperado de https://doi.org/10.15348/1980-6906/psicologia.v16n2p41 
Machado, A. R. (2006). Uso prejudicial e dependência de álcool e outras drogas na agenda da saúde pública: um estudo sobre o processo de constituição da política pública de saúde do Brasil para usuários de álcool e outras drogas. 151p. Dissertação (Mestrado em Saúde Pública). Faculdade de Medicina, Universidade Federal de Minas Gerais, Belo Horizonte.

MacRae, E. J. B. N. (2007). Aspectos socioculturais do uso de drogas e políticas de redução de danos. In Anais, XIV Encontro Nacional da Associação Brasileira de Psicologia Social. Rio de Janeiro: ABRAPSO.

Mansilla, N. K. R., \& Bento, V. E. S. (2006). Drogadicção: tentativa de suicídio e/ou elaboração? Revista Do Departamento de Psicologia. UFF, 18(2), pp. 11 28. Recuperado de https://doi.org/10.1590/S0104-80232006000200002

Mattos Filho de, C. R. (2009). Entre o adolescente e a droga, o pai: tanto nos amores como nos chinelos. (pp.161-187). In A. Nery Filho et al. (orgs). Toxicomanias: incidências clínicas e socioantropológicas. Salvador: EDUFBA, 2009.

Max, R., \& Danziato, L. (2015). Drogas, biopolítica e subjetividade: interfaces entre psicanálise e genealogia. Revista Subjetividades, 15(3), 417-427. Recuperado http://ojs.unifor.br/index.php/rmes/article/view/5115\%0Ahttp://document/vie $\mathrm{w} / \mathrm{mzaxs}$

Melman, C. (2005). Toxicomanias. In C. Melman. A prática psicanalítica hoje: conferências, (pp. 169-181). Rio de Janeiro: Tempo Freudiano, 2008.

Mendonça, J. R. da S. (2011). A droga como um recurso ao mal-estar na civilização. Psicologia Em Revista, 17(2), (pp. 240-260).

Nespoli, N. S., Novaes, J. de V., \& Madureira, B. (2018). Seria a comida um objeto tóxico? Aproximações entre a compulsão alimentar e a toxicomania. Trivium: Estudos Interdisciplinares, 10(1), 83-95. Recuperado de https://doi.org/http://dx.doi.org/10.18379/2176-4891.2018v1p.83

Olievenstein, C. (1985). Destino do toxicômano. São Paulo: ALMED.

Oliveira, M. T. de, Winograd, M., \& Fortes, I. (2016). A Pulsão de Morte Contra a Pulsão de Morte: a Negatividade Necessária. Psicologia Clinica, 28(2), 88. Recuperado de http://pepsic.bvsalud.org/pdf/pc/v28n2/05.pdf

Organização Mundial da Saúde. (2001). Classificação de transtornos mentais e de comportamento da CID-10: referência rápida. Porto Alegre: Artes Médicas.

Pacheco Filho, R. A. (2007). Toxicomania: um modo fracassado de lidar com a falta estrutural do sujeito e com as contradições da sociedade. Mental, Barnacena, 5(9), 29-45.

Pages-Berthier, J. (1993). Psychanalyse et Toxicomanie. Toxibase, v. 2 (93), (pp. 44-70). Lyon. 
Pereira, D. R., \& Migliavacca, E. M. (2014). Aspectos da compulsão à repetição na toxicomania. Cadernos de Psicanálise (CPRJ), Rio de Janeiro, 36(30), 71-87.

Pimenta, S. N., Cremasco, M. V. F., \& Lesourd, S. (2011). Clínica da toxicomania: Uma expressão melancólica? Revista Latinoamericana de Psicopatologia Fundamental, 14(2), 252-267. Recuperado de https://doi.org/10.1590/S141547142011000200004

Pinheiro, T. (2012). O modelo melancólico e os sofrimentos da contemporaneidade. In J. Verztman et al (orgs). Sofrimentos Narcísicos. (pp. 17-38). Rio de Janeiro: Cia de Freud.

Ribeiro, R. F. (2005). Tortuosas raízes medicinais: as mágicas origens da farmacopéia popular brasileira e sua trajetória pelo mundo. In Venâncio, R. P \& Carneiro, H. (orgs), Álcool e drogas na história do Brasil (pp.155-184). Belo Horizonte: Editora Pucminas.

Ribeiro, C. T. (2009). Que lugar para as drogas no sujeito? Que lugar para o sujeito nas drogas?: Uma leitura psicanalítica do fenômeno do uso de drogas na contemporaneidade. Ágora: Estudos Em Teoria Psicanalitica, 12(2), pp. 333346. Recuperado de https://doi.org/10.1590/S1516-14982009000200012

Rodrigues, T. (2005). Narcotráfico: um esboço histórico In Venâncio, R. P \& Carneiro, H. (orgs), Álcool e drogas na história do Brasil (pp.291-310). Belo Horizonte: Editora Pucminas.

Rodrigues, J. A. (2012). A aplicabilidade do dispositivo clínico-institucional urgência subjetiva no tratamento da toxicomania. Mental, Barbacena, 10(18), 69-88.

Rosa, P. O. (2014). Outra história do consumo de drogas na modernidade. Caderno de Terapia Ocupacional UFSCar, São Carlos, v. 22, n. Suplemento Especial, pp. 185-196. Recuperado de https://doi.org/http://dx.doi.org/10.4322/cto.2014.041

Rosenfeld, H. (1960). On Drug Addiction. In H. Rosenfeld. Psychotic States: A Psycho-Analytical Approach. (pp. 128-143). Londres: Karnac Books, 1965.

Rosenfeld, H. (1964). The Psychopathology of Drug Addiction and Alcoholism: A critical review of the psycho-analytic literature. In H. Rosenfeld. Psychotic States: A Psycho-Analytical Approach. (pp. 217-242). Londres: Karnac Books, 1965.

Roudinesco, E. \& Plon, M. (1998). Dicionário de psicanálise. In V. Ribeiro \& L. Magalhães (trad.). Rio de Janeiro: Zahar.

Santiago, J. (2017). A droga no toxicômano: uma parceria cínica na era da ciência. (2 ed). Belo Horizonte: Relicário edições.

Santos, C. E. dos, \& Costa-Rosa, A. da. (2007). A experiência da toxicomania e da reincidência a partir da fala dos toxicômanos. Estudos de Psicologia, 
Campinas, 24(4), 487-502. Recuperado de https://doi.org/10.1590/S0103166X2007000400008

Santos, F. S. D. \& Verani, A. C. (2010). Alcoolismo e medicina psiquiátrica no Brasil no início do século XX. História, Ciências, Saúde - Manguinhos, Rio de Janeiro, v.17, n.2, pp. 401-420.

Sedeu, R. de L. (2014). Da toxicomania à adicção: uma abordagem relacional. Estudos de Psicanálise, 42, 107-120. Recuperado de http://teachersinstitute.yale.edu/curriculum/units/1986/5/86.05.03.x.html\#top

Serretti, M. A. T. (2012). Toxicomania: um estudo psicanalítico. Mosaico: Estudos Em Psicologia, 5(1), 46-60.

Silveira, E. R. (2013). Clínica da toxicomania: recortes de uma experiência em CAPS AD. Revista Mal Estar e Subjetividade, 13(3/4), 665-686. Recuperado de http://pepsic.bvsalud.org/scielo.php?script=sci_arttext\&pid=S151861482013000200010\%0Ahttp://ojs.unifor.br/index.php/rmes/article/view/509 9

Vanier, Alain. (1998). O Imaginário. In A. Vanier. Lacan. (pp.35-51). São Paulo: Estação da Liberdade., 2005.

Zimerman, D. (2008). Vocabulário contemporâneo de psicanálise. Porto Alegre: Artmed. 